\title{
CARGAS ELÉTRICAS E SELETIVIDADE CATIÔNICA DE SOLOS COM CARGA VARIÁVEL MEDIDAS PELO MÉTODO DA ADSORÇÃO DE CÉSIO
}

\author{
OSCARLINA LÚCIA DOS SANTOS WEBER \\ Engenheira Agrônomo \\ Orientador: Prof. Dr. JOSÉ CARLOS CHITOLINA

\begin{abstract}
Tese apresentada à Escola Superior de Agricultura "Luiz de Queiroz", Universidade de São Paulo, para obtenção do título de Doutor em Agronomia, Área de Concentração: Solos e Nutrição de Plantas
\end{abstract}

PIRA CI CABA

Estado de São Paulo - Brasil

Janeiro - 2000 


\section{ERRATA}

\begin{tabular}{|c|c|c|c|}
\hline Página & Linha & Onde se lê & Leia-se \\
\hline vi e 2 & 4 e 15 & ..valores de capacidade de troca & $\begin{array}{l}\text {...valores de capacidade de roca } \\
\text { catiônica efetiva }\end{array}$ \\
\hline vii e viii & 12,13 e 4 & ...superficiais e subsuperficiais & superficial e subsuperficial \\
\hline 1 & 19 & ...no balanço como a adição & $\begin{array}{l}\text {...no balanço de cargas bem } \\
\text { como a adição }\end{array}$ \\
\hline 8 e 16 & 18 e 13 & $\begin{array}{l}\text {.. a diferença de moles de próton e } \\
\text { moles de íons }\end{array}$ & $\begin{array}{l}\text {... a diferença de mols de próton } \\
\text { e mols de íons }\end{array}$ \\
\hline 10 & 16 & ... A natureza acídica & ... A natureza ácida \\
\hline 15 & última linha & ... a lei daconservação quie não & ... a lei ch conservação das cargas que não \\
\hline 20 & 16 & ...das regiões isopertérmica & ...das regiões isohipertérmica \\
\hline 25 & 5 & ...de argila e do ácido húmico pelos & $\begin{array}{l}\text {...de argila e das substâncias } \\
\text { húmicas pelos }\end{array}$ \\
\hline 27 & 5 & ...ou mole princípio HSAB & $\begin{array}{l}\text {...ou mole baseado no princípio } \\
\text { HSAB }\end{array}$ \\
\hline 37 & 19 & $\ldots$ a caulinita, $30-440 \mathrm{cmol}_{\mathrm{c}} \mathrm{kg}^{-}$ & $\ldots$ a caulinita, $30-40 \mathrm{cmol}_{\mathrm{c}} \mathrm{kg}^{-}$ \\
\hline 44 e 50 & 16 e 19,24 & $\ldots$ vortexer & ... vortex \\
\hline 50 & 21 & ...netre & ...entre \\
\hline 76 & 26 & ... da fração deferricida & ... da fração deferrificada \\
\hline 108 & 25 & ... seletividad & ... seletividade \\
\hline 109 & última linha & ... a fração orgânica consituiu-se no... & $\begin{array}{l}\text {... a fração orgânica constituiu-se } \\
\text { no... }\end{array}$ \\
\hline 111 & 6 & ... o aumento foi verifcado & ... o aumento foi verificado \\
\hline
\end{tabular}

Obs: Em todas as Tabelas na coluna Prof (cm) onde se lê: " LR ác-Rib 100-140, LUna ác-argare 30-70, LUna ác-mtarg 60-90" leia-se: " LR ác-Rib 100-180, LUna ác-argare 40-60, LUna ác-mtarg 90-110". 
Dados Internacionais de Catalogação na Publicação (CIP) DIVISÃO DE BIBLIOTECA E DOCUMENTAÇÃO - Campus "Luiz de Queiroz"/USP

\author{
Weber, Oscarlina Lúcia dos Santos \\ Cargas elétricas e seletividade catiônica de solos com carga variável medidas pelo \\ método da adsorção de césio / Oscarlina Lúcia dos Santos Weber. - - Piracicaba, 2000. \\ $155 \mathrm{p}$. \\ Tese (doutorado) - Escola Superior de Agricultura Luiz de Queiroz, 2000. \\ Bibliografia. \\ 1. Adsorção 2. Carga elétrica 3. Césio 4. Quimica do solo 5. Solo ácrico 6. Troca \\ catiônica I. Título
}

CDD 631.44

"Permitida a cópia total ou parcial deste documento, desde que citada a fonte - $O$ autor" 
Aos meus pais (in memorian) pelo abnegado esforço que fizeram em meu proveito; às minhas irmãs Aracy e Madalena e aos meus amigos Paulo Sérgio e Vera Júlia

OFEREÇO

À Eduardo e aos meus filhos

Alfredo, Renan e Emerson 


\section{AGRADECIMENTOS}

À DEUS que nunca deixou nada me faltar e por me dar equilíbrio;

Ao Professor Dr. José Carlos Chitolina pela orientação que se fez constantemente acompanhada de amizade, apoio, liberdade, confiança, encorajamento e pelo exermplo;

Ao Professor Dr. Otávio Antônio de Camargo pela orientação, confiança, pelas idéias, pela amizade e pelo exemplo;

À Coordenação de Pós-Graduação do Curso de Solos e Nutrição de Plantas e seus membros pela receptividade, oportunidade e atenciosidade;

À UFMT-FAMEV pela oportunidade concedida;

À Coordenação de Aperfeiçoamento de Pessoal de Nível Superior- CAPES- pela bolsa concedida.

Ao Dr. Luiz Reynaldo F. Alleoni pelo apoio e amizade.

Ao Dr. Ricardo Trippia dos Guimarães Peixoto pela ajuda, troca de idéias e cordialidade.

Ao corpo docente e funcionários do Setor de Química, Departamento de Ciências Exatas-ESALQ/USP, pelo apoio e amizade que sempre me dedicaram;

Ao Setor de Mineralogia, na pessoa de Maria Elisabete Honório Bete Guimarães, Departamento de Ciências do Solo e Nutrição de Plantas pelo apoio e amizade;

À Prof ${ }^{\natural}$. Dr ${ }^{\mathrm{a}}$ Célia Regina Montes-Lauar e funcionários da NUPEGEL, pelo apoio nas análises mineralógicas e cordialidade;

Às secretárias Maria Angélica e Giovana pela presteza e eficiência na resolução de problemas burocráticos.

Aos colegas Ana Rosa, Femando Carvalho, Marcelo Alves, Fábio Vale, Fábio Prata, Edna Bertunucci, Tadeu, Nagib e tantos outros pelo convívio amigo e harmonioso; 


\section{SUMÁRIO}

Página

RESUMO

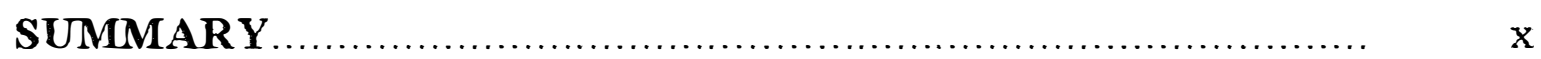

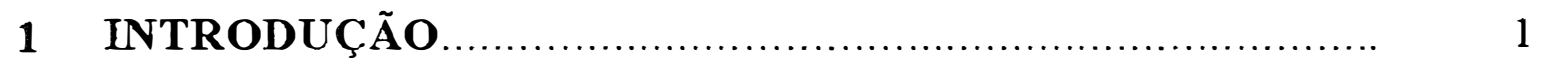

2 REVISÃO DE LITERATURA ................................

$2.1 \quad$ Cargas de Superficie. ........................................................ 4

2.2 Componentes de Carga Elétrica de Superfície.............................. 15

2.3 Métodos para medir as cargas de superfície.................................. 18

2.4 Conceito de Ácidos e Bases Duros e Moles (HSAB) de Lewis........ 24

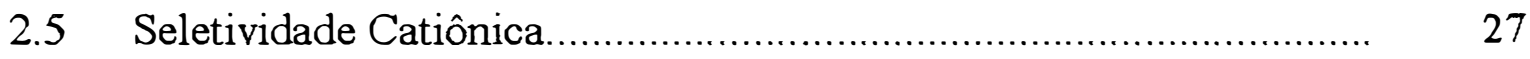

2.6 Reações do césio em sítios com carga permanente e em sítios de

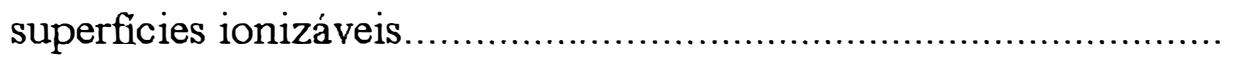

2.7 Efeito da remoção da matéria orgânica e dos óxidos de ferro no

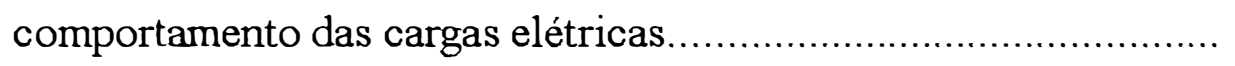

3 MATERIAL E MÉTODOS ...................................................... 41

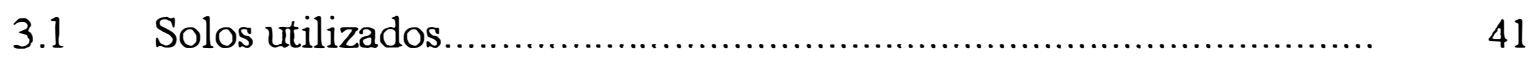

3.2 Análises químicas, físicas e mineralógicas.............................. 42

3.3 Parte experimental............................................................... 47 


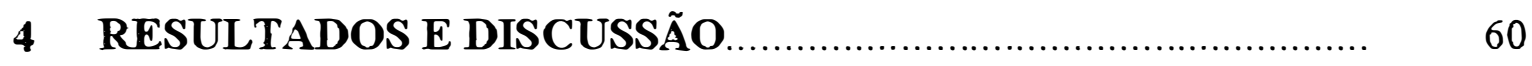

4.1 Análises químicas e eletroquímicas............................................ 60

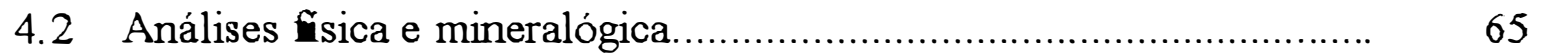

4.3 Medida das cargas permanentes e variáveis pelo método da adsorção de césio em uma Terra Roxa e em quatro solos ácricos originais.

4.4 Coeficientes de seletividade condicionais $\left({ }^{\mathrm{C}} \mathrm{K}_{\mathrm{EX}}\right)$ para a troca $\mathrm{Li} \rightarrow$ $\mathrm{Cs}^{+}$em solos originais.

4.5 Comportamento das cargas elétricas após remoção da matéria orgânica e dos óxidos de ferro.

4.6 Coeficientes de seletividade condicionais $\left({ }^{\mathrm{C}} \mathrm{K}_{\mathrm{EX}}\right)$ para a troca $\mathrm{Li}^{+} \rightarrow$ $\mathrm{Cs}^{+}$em solos com matéria orgânica e óxidos de ferro removido.

5 CONCLUSÕES 


\title{
CARGAS ELÉTRICAS E SELETIVIDADE CATIÔNICA DE SOLOS COM CARGA VARIÁVEL MEDIDAS PELO MÉTODO DA ADSORÇÃO DE CÉSIO
}

\author{
Autor: OSCARLINA LÚCIA DOS SANTOS WEBER \\ Orientador: Prof. Dr. JOSÉ CARLOS CHITOLINA
}

\section{RESUMO}

Na região Norte Paulista, extensas áreas agrícolas são cultivadas com cana de açúcar, soja, feijão e trigo num nível tecnológico elevado, englobando solos tropicais com cargas variáveis de caráter ácrico. Estes solos caracterizam-se por apresentarem baixíssimos valores de capacidade de troca $\left(<1,5 \mathrm{cmol} \mathrm{kg}^{-1}\right.$ argila) sendo suas frações argila predominantemente constituídas por caulinita, hidróxidos de Fe e a gibbsita. Embora de constituição simples, esses minerais mostram uma grande diversidade de características como, tamanho de partículas, exposição de faces, graus de substituição isomórfica etc., o que os leva a apresentar comportamentos diferenciados em importantes reações do solo. A diversidade das características é atribuída, principalmente, aos diferentes ambientes de formação desses minerais.

Essa diversidade de características influi de maneira decisiva no balanço de cargas permanentes e variáveis desses solos. Além disso, as práticas agrícolas 
como a adição de corretivos, fertilizantes e matéria orgânica também devem influir significativamente no balanço das cargas totais.

Embora eles tenham grande importância econômica, geográfica e taxonômica o seu comportamento eletroquímico tem sido pouco estudado. A literatura elucida que aspectos sobre manejo e gênese desses solos podem ser usados como padrão para uma ampla faixa de solos que ocorrem em condições tropicais.

Os objetivos do presente trabalho foram quantificar as cargas elétricas de solos com material ácrico e estudar os efeitos da remoção de óxidos e da matéria orgânica, no comportamento de quatro latossolos ácricos e uma Terra Roxa Estruturada.

Foram utilizadas amostras de solos a duas profundidades, superficiais e subsuperficiais na maior expressão do horizonte B. Tendo sido estudados dois latossolos roxos ácricos (LR ác-Rib e LR ác-Gua) e dois latossolos ácricos variação Una (LUna ác-argare e LUna ác-mtarg) das regiões de Ribeirão Preto, Guaíra e Miguelópolis e uma Terra Roxa Estruturada do município de Ribeirão Preto.

Estas amostras de solo foram investigadas pelo método da adsorção iônica desenvolvido para medir a carga permanente $\left(\sigma_{\mathrm{O}}\right)$ e comparada com uma TE com predomínio de carga permanente. $O$ método baseou-se na preferência que os sítios siloxanos de superficie têm para $\mathrm{Cs}^{+}$sobre $\mathrm{Li}^{+}$e de grupos de superfície ionizáveis de menor seletividade ao íon $\mathrm{Cs}^{+}$.

A caracterização mineralógica dos óxidos de ferro e da fração argila total por difratometria de raio $\mathrm{X}(\mathrm{DRX})$ e análise térmica diferencial também foram feitas. Os coeficientes de seletividade condicionais foram determinados nos solos originais e para aqueles cuja matéria orgânica e óxidos de ferro foram removidos a partir das frações molares dos íon césio e das cargas permanentes e totais obtidas na determinação das cargas estruturais pelo método de adsorção do césio. 
Os resultados obtidos mostraram que a porcentagem da carga variável representou mais que $50 \%$ das cargas totais dos solos originais avaliados. Eles revelaram um valor mínimo de 55\% para a TE e um máximo de $77 \%$ para o LUna ác-mtarg para camada superfical. Para a camada mais profunda eles apresentaram um valor mínimo de $47 \%$ para a TE e um máximo de $73 \%$ para ambos os solos, LR ác-Gua e LUna ác-argare. Os latossolos ácricos exibiram significante quantidade de carga permanente a qual pode ser atribuída à baixas quantidades de vermiculita com hidróxido de alumínio nas entrecamadas e de clorita, ambos detectados pela DRX. A quantidade de carga permanente apresentada pela TE comparada ao Latossolo ác-Gua foi cinco vezes superior que é devido, provavelmente, à diferença mineralógica. Aproximadamente 23 a 34\% das cargas negativas a pH 6,0 dos latossolos ácricos e 45 a 53\% da TE resultou da contribuição das cargas permanentes. Considerando os Latossolos Roxos ácricos a carga permanente diminuiu à medida que o índice de intemperização (ki) diminuiu exceto para os Latossolos ácricos variação Una. A complexação do césio pela matéria orgânica conduziu a valores de carga permanente superestimados.

Nos solos onde a matéria orgânica foi removida, as cargas variáveis apresentaram-se reduzidas na superficie, exceção do LUna ác-argare que manteve essa mesma quantidade de carga e, aumentadas na subsuperficie. As cargas permanentes na superficie diminuíram para os solos TE e LUna ác-argare, para os demais houve acréscimo. Estas cargas aumentaram para todos os solos na subsuperficie. As cargas totais mostraram predomínio das cargas variáveis nas duas profundidades para quase todos os solos, exceto a TE. Este solo mostrou predomínio das cargas permanentes em profundidade, refletindo igual participação dos dois tipos de cargas na capacidade de troca catiônica.

Nos solos onde os óxidos de ferro amorfos e livres foram removidos, todas as cargas aumentaram nas duas profundidades para todos os solos avaliados. As 
cargas permanentes apresentaram predomínio sobre as variáveis na camada superficial para quase todos os solos. Na subsuperficie a carga variável predominou sobre a permanente para todos os solos.

A contribuição das cargas variáveis pode estar diretamente relacionada com os materiais oxídicos presentes nos perfis, principalmente na forma livre.

Os coeficientes de seletividade mostraram adsorção preferencial para césio para todos os solos. O maior coeficiente de seletividade condicional ao íon césio foi obtido pelo LUna ác-argare e os menores pelos LR ác-Gua e LUna ác-mtarg. Com a remoção de matéria orgânica, a TE exibiu maior seletiva seletividade. Entre os latossolos ácricos, o LUna ác-argare mostrou ser mais seletivo ao íon césio. Após a remoção dos óxidos de ferro amorfos, o LUna ác-mtarg mostrou ser o mais seletivo ao íon césio e após a remoção dos óxidos de ferro livres, o LR ácGua; mostrou ter maior seletividade ao íon césio. Os solos comportaram-se como trocadores não ideais.

O método foi capaz em quantificar significativa quantidade de carga permanente mesmo em solos com baixas quantidades de argilominerais 2:1. 


\section{ELECTRIC CHARGES AND CATIONIC SELECTIVTTY OF VARIABLE \\ CHARGE SOILS MEASURED BY THE CESIUM ADSORPTION \\ METHOD}

\section{Author: OSCARLINA LÚCIA DOS SANTOS WEBER Adviser: Dr. JOSÉ CARLOS CHITOLINA}

\section{SUMMARY}

In the north of São Paulo State-Brazil, we have very big sugar cane, soy bean, bean and wheat producing areas using high technology where the soil is classified as acric Oxisols. These soils are characterized by having a lower

exchange capacity $\left(<1,5 \mathrm{cmol} \mathrm{kg}^{-1}\right.$ clay) due to their kaolinite, iron hydroxy and gibbsite composition. Although they have a very simple composition, these minerals show a great diversity of characteristics such as particle size, face exposition, isomorphic substitution levels etc. This may lead them to have different behavior in important soil reactions. Their diversity of characteristics is due mainly to the different formation environments where they are found.

This diversity of characteristics has a vital role in the permanent and variable charge balance of these soils. Besides this fact, agriculture practices as added amendments, fertilizers and organic matter must also have a very strong influence on the total charge balance.

They also have a relevant economical, geographical and taxonomic function but their electrochemical behavior has been little studied. The literature 
elucidates that aspects on management and genesis of these soils may be used as a standard for a large range of tropical soils.

The aims of this paper were to quantify the electric charges of acric soils and to study the oxide and organic matter removal in the behavior of four acric Oxisols and one Alfisol (TE).

Surface soil samples and deeper layer samples from B horizon were used. Four acric Oxisols, two classified as Dusk-Red Latosol (LR ac-Rib and LR acGua) and two as Una variant Latosol (Luna ac-argare and Luna ac-mtarg), were collected from Ribeirão Preto, Guaira and Miguelópolis regions, in the North of São Paulo State-Brazil.

These soil samples were investigated by an ion adsorption method developed to measure the structural charge density $\left(\sigma_{0}\right)$ and compared to an Alfisol (TE) which had a predominantly permanent charge. The method is based on the preference of siloxane surface sites for cesium over lithium and on the lower selectivity of ionizable surface group for ion cesium.

The mineralogical characterization for iron oxides and total clay by $\mathrm{X}$-ray difratome $(\mathrm{XRD})$ and differential thermal analysis were carried out. The conditional selectivity coefficients were determined for the original soils and for those whose organic matter and iron oxides were removed.

The results obtained showed that the variable charge percentage represented more than $50 \%$ of the total soil charges evaluated. They revealed a minimum value of $55 \%$ to an Alfisol (TE), and a maximum value of $77 \%$ to an Una variant Latosol (LUna ác-mtarg) for the surface layer. For the deeper layer, they presented a minimum value of $47 \%$ to the Alfisol and a maximum of $73 \%$ for both Dusky-Red Latosol (LR ác-Gua) and Una variant Latosol (LUna ácargare). The acric soils exhibit significant structural charge amounts which may be attributed to small quantities of aluminium hydroxy-interlayer vermiculite and chlorite, detected by XRD. The amount of permanent charge presented by the 
Alfisol as compared to the Dusky-Red Latosol (LR ác-Gua) was five times higher, which is, probably, due to differences in the mineralogy. Approximately 23 to $34 \%$ of the negative charges at $\mathrm{pH} 6.0$ of acric Oxisols and 45 to $53 \%$ of the Alfisols resulted from permanent charge contributions. Considering the acric Dark-Red Latosol, the structural charges decreased as the weathering index decreased except for the Una variant Latosols. The complexation of cesium by organic matter led to overestimated values for the structural charges.

In the soils where the organic matter was removed, the variable charges showed a decrease in the surface, except for the Una variant Latosol that maintained this charge quantity steady and increased in the deeper surface. Permanent charges in the surface decreased for Alfisol (TE) and Una variant latosol soils, but they increased for the others. These charges increased for all the soils in the deeper surface. The total charges showed a predominance of the variable charges in the two layers for almost all the soils, except for Alfisol (TE). This soil showed a predominance of permanent charges in the deeper layer, reflecting the same participation of the two kinds of charges in the cationic exchange capacity.

In the soils where amorphous and free iron oxides were removed, all the charges increased in the two layers for all soils evaluated. The permanent charges showed a predominance in the surface layer for almost all the soils. In the deeper layer the variable charge was more predominant.

The variable charge contribution can be directly related to the oxides present in the two layers, mainly in the free state.

The selectivity coefficients showed a preferential adsorption to cesium for all the treatments. The highest selectivity coefficient to the ion cesium was obtained by the Una variant Latosol and the lowest ones by the Dusk-Red Latosols. After the organic matter removal, Alfisol exhibited the highest selectivity. Among the acric Oxisols, the LUna ác-argare showed to be more 
selective to the ion cesium. After the amorphous iron oxide removal, the LR ácGua showed higher ion cesium selectivity. Soils behaved as non- ideal exchangers for all the treatments.

This method was able to quantify significant amounts of permanent charges even in soils with low amounts 2:1 of clay minerals. 


\section{INTRODUÇÃO}

Solos altamente intemperizados, como latossolos e podzólicos, são importantes nas regiões de clima tropical e subtropical, predominantes no território brasileiro e de grande relevância na América Latina. Eles ocupam grandes áreas exploradas agricolamente e exercem papel de destaque na produção de alimentos e nos estudos de ambiente.

Por terem sofrido alto grau de intemperismo, a fração argila desses solos é dominada por argilominerais do tipo 1:1, constituída predominantemente de caulinita, e óxidos de $\mathrm{Fe}, \mathrm{Al}$ e $\mathrm{Mn}$, o que lhes confere atributos de carga elétrica variável. A origem dessas cargas está ligada ao ganho ou perda de $\mathrm{H}^{+}$do grupo funcional hidroxila na superficie desses colóides.

A caulinita é o principal mineral silicatado em quantidade expressiva, sendo a goetita e a hematita os principais óxidos de ferro e a gibbsita, quase exclusivamente, o único óxido de $\mathrm{Al}$ presente nesses solos. Embora de constituição simples esses minerais mostram uma grande diversidade de características tais como tamanho de partículas, exposição de faces, graus de substituição isomórfica etc, o que os leva a apresentar comportamentos diferenciados em importantes reações do solo. A diversidade das características é atribuída, principalmente, aos diferentes ambientes de formação desses minerais.

Essa diversidade de características influi de maneira decisiva no balanço como a adição de corretivos, fertilizantes e matéria orgânica também devem influir significativamente no balanço das cargas totais. 
Assim, o entendimento do comportamento das cargas elétricas dos colóides, constitui-se num importante conhecimento para o adequado manejo dos solos do trópico úmido (Morais et al., 1976) como também pode constituir-se em relevante ferramenta para o estudo da gênese de solos (Hendershot \& Lavkulich, 1978). Alguns fenômenos como adsorção e dessorção de íons e a dispersão e floculação dos colóides também são influenciados pela natureza das cargas elétricas.

Após o trabalho de Raij \& Peech (1972), o estudo das propriedades eletroquímicas de solos tropicais com cargas variáveis intensificou-se abrangendo diversos tipos de solos principalmente, os Oxissolos, Ultissolos e Andissolos (Morais et al., 1976; Wada \& Wada, 1985; Gillman \& Sumner, 1987; Sakurai et al., 1990). Dentre eles, estão os que apresentam material ácrico, com baixíssimos valores de capacidade de troca catiônica ( $\mathrm{CTC}<1,5 \mathrm{cmol} / \mathrm{kg}$ de argila) e cuja fração argila é predominantemente constituída por hidróxidos de $\mathrm{Fe}$ e $\mathrm{Al}$ (Uehara, 1988). Estes solos, muito freqüentes em regiões próximas à linha do Equador, ocorrem no estado de São Paulo numa vasta área da região nordeste (Oliveira et al., 1991 ) que apresenta intensa atividade agrícola.

Embora eles representem grande importância econômica, geográfica e taxonômica o seu comportamento eletroquímico tem sido pouco estudado. Os trabalhos de Alleoni (1992) e de Casagrande (1993) sugerem alguns caminhos importantes para elucidarem questões sobre manejo e gênese desses solos que devido às suas características poderão servir de padrão para uma ampla gama de solos que ocorrem em condições tropicais. Os objetivos do presente trabalho foram: 1) quantificar as cargas elétricas permanentes e variáveis de materiais muito intemperizados como os solos com material ácrico e 2) estudar os efeitos da remoção de óxidos e da matéria orgânica, no comportamento das cargas elétricas. 
Hipótese: Conforme os solos intemperizam deve diminuir muito a carga permanente, e a contribuição das cargas variáveis deve estar muito relacionada com os materiais oxídicos presentes no perfil. 


\section{Revisão de Literatura}

\subsection{Cargas de superficie}

2.1.1 Importância e desenvolvimento das cargas de superfície

A maioria das reações que ocorrem no sistema água- solo são fenômenos de superfície e, dependendo da atividade da superfície das partículas do solo, tanto a fração mineral da argila quanto a matéria orgânica coloidal, constituem a principal sede dos fenômenos físico-químicos que nele se processam. A adsorção e dessorção de íons e a dispersão e floculação de colóides são importantes processos que ocorrem como conseqüência das propriedades elétricas das superfícies coloidais e são muito bem explicadas por meio da superfície específica e das cargas elétricas dos colóides (Bohn et al., 1979). Um bom entendimento da quantidade e distribuição de cargas na superfície dos colóides e seus pontos de carga zero (PCZs) podem ser úteis para: (1) explicar as adsorções de ocorrência natural e sintetizadas; (2) contribuir na interpretação de algumas propriedades físicas como, por exemplo, a coagulação (Healy et al., 1966, 1968; Parks, 1967; Breewsma \& Lyklema, 1973; Hohl et al., 1980), a agregação (Gillman, 1974; Sumner, 1992), a mobilidade eletroforética (Healy et al., 1968;

Murray, 1974) e de algumas propriedades químicas como, por exemplo, a 
capacidade de troca catiônica (CTC) e capacidade de troca aniônica (CTA) (Schofiled, 1949; van Raij \& Peech, 1972; Gillman, 1984; Gillman \& Sumpter, 1986; Gillman \& Sinclair, 1987; Peixoto, 1995; Peixoto et al., 1995 a, b); (3) entender o comportamento da carga de superficie em função do $\mathrm{pH}$ e da força iônica da solução do solo; (4) validar os modelos moleculares (Charlet \& Sposito, 1987); (5) avaliar o desenvolvimento pedogenético (Hendershot \& Lavkulich, 1978;). Diante de tal fato, um entendimento do comportamento das cargas elétricas superficiais, se faz necessário, não só para recomendar um manejo adequado aos diversos tipos de solos encontrados nas regiões dos trópicos úmidos (Morais et al., 1976) como também para entender a evolução desses solos.

A origem e a natureza da carga são importantes na delimitação da magnitude de propriedades físicas e químicas dos solos como: troca iônica, adsorção de ânions e interações de partículas. Os tipos de cargas elétricas nos colóides dos solos compreendem a carga fixa ou permanente, a qual independe da composição da solução, sendo que o potencial elétrico é sensivel na concentração de eletrólitos indiferentes, e a carga variável que varia com a mudança da concentração dos eletrólitos indiferentes sendo que o potencial elétrico permanece constante a um mesmo $\mathrm{pH}$. As cargas elétricas se desenvolvem na superficie da partícula sólida do solo por meio de três processos principais (Bell \& Gillman, 1978; Bohn et al., 1979, Stumm \& Morgan, 1981 e Sposito, 1992): (1) substituição isomórfica; (2) dissociação e associação de prótons $\left(\mathrm{H}^{+}\right)$ (protonação/deprotonação) e (3) adsorção específica de cátions e ânions. As cargas permanentes ou constantes $\left(\sigma_{\mathrm{O}}\right)$, são resultantes do primeiro processo, enquanto que as cargas variáveis $\left(\sigma_{\mathrm{H}}\right)$, desenvolvem-se pelos dois últimos processos. 


\subsubsection{Cargas permanentes}

O conhecimento da carga elétrica permanente $\left(\sigma_{0}\right)$ como componente de carga superficial das partículas do solo é fundamental para a compreensão e previsão do destino de elementos químicos no solo. $O$ seu valor também é necessário para as determinações dos outros componentes de densidade de carga superficial e dos pontos de carga zero nos solos (Sposito, 1992).

A carga permanente é aquela criada pela substituição isomórfica na estrutura dos minerais. Essas substituições isomórficas ocorrem nos minerais primários, na sua formação magmática, e nos secundários na formação do solo (Gast, 1977). Ela se desenvolve por meio da substituição de íons de tamanhos semelhantes, mas com diferentes cargas no látice dos argilominerais.

Sendo assim, as cargas negativas permanentes têm sua origem no desbalanceamento estrutural de cargas elétricas, causado pelas substituições isomórficas de cátions de maior valência (silício tetravalente, por ex.) por cátions de menor valência (alumínio trivalente por ex.) na camada tetraédrica, e na substituição de alumínio trivalente por magnésio divalente por ex., na camada octaédrica nos minerais. Estas substituições ocorrem tanto nos minerais primários, na sua formação magmática, como nos minerais secundários, na formação do solo, mas elas produzem significante carga de superficie somente nos minerais do tipo 2:1. A contribuição para a carga permanente da substituição isomórfica nos óxihidróxidos e silicatos do tipo 1:1, como a caulinita, tipicamente é menor que $20 \mathrm{mmol} \mathrm{kg}^{-1}$ (Sposito, 1989).

Por outro lado, as micas e os argilominerais ilita, vermiculita, esmectita e vermiculita-muscovita com hidróxidos entre camadas são constituintes potenciais menores (Herbillon,1981; Hughes, 1981; Le Roux, 1973). Por exemplo, nas micas comuns, muscovita e biotita, todos os quatro íons de silício tetravalente é substituído por um íon alumínio, trivalente, resultando num déficit de carga que é 
balanceado internamente pelos íons $\mathrm{K}^{+}$nas posições entrecamadas. Estes minerais podem ser dominantes em oxissolos derivados de materiais de rochas ácidas como, quartzito, granito, gnaisse, micaxisto e arenito, ou desenvolvidos sob condições de má drenagem (Juo, 1981).

O mais importante mineral de argila $1: 1$ encontrado nos solos dos trópicos úmidos é a caulinita. Esse mineral em geral ocorre em placas cristalinas hexagonais. Um simples cristal, apresenta arestas e duas superficies, uma formada de tetraedros de sílica e outra de octaedros de alumina (Raij, 1986). A carga negativa permanente nesse argilomineral está localizada na superfície siloxana da camada tetraédrica e é criada pela substituição isomórfica de silício tetravalente por alumínio trivalente (Greenland \& Mott, 1978; Sposito, 1983) .

Schofield \& Samson (1954) ao observarem a retenção de $\mathrm{Na}^{+}$sob condições ácidas, postularam que carga negativa permanente em caulinita é gerada de substituição isomórfica. Embora possa existir substituição isomórfica na caulinita, há uma crescente evidência que quantidades de minerais 2:1 não detectáveis sejam responsáveis pela medida da carga permanente. Komameni (1978) encontrou que o número de extrações necessárias para dessorver $\mathrm{Cs}^{+}$das várias caulinitas comerciais estavam correlacionadas com a presença de impurezas, como micas e smectitas. Lim et al. (1980), encontraram picos de DRX para argila 2:1 em seis amostras comerciais tornando evidente a dissolução seletiva da caulinita.

$\mathrm{Na}$ ausência de argila silicatada, a carga permanente negativa pode resultar da substituição isomórfica do alumínio trivalente pelo magnésio divalente na gibbsita (Tschapek, 1974) e pela substituição do ferro trivalente pelo magnésio divalente (Gallez et al.,1976; Parks, 1967) em óxidos de ferro.

Por outro lado, a carga permanente positiva é desenvolvida pela substituição de cátions de menor valência por cátions de maior valência. A presença de carga permanente positiva em algumas amostras de um Acrohumox 
rico em gibbsita e goetita foi relatada por Raij \& Peech (1972) e é atribuída à substituição isomórfica de ferro trivalente ou alumínio trivalente por titânio tetravalente ou manganês tetravalente (Sumner, 1963; Tessen \& Zauyah, 1982). A substituição isomórfica de ferro $\left(\mathrm{Fe}^{+3}\right)$ por alumínio $\left(\mathrm{Al}^{+3}\right)$ em óxihidróxido de ferro afeta a química de superfície por causa da mudança em tamanho, forma e superficie específica destes minerais sem entretanto, criar carga . Há relatos que na caulinita a carga positiva permanente aparece em virtude de alguma substituição de alumínio trivalente por titânio tetravalente na camada tetraédrica (Weaver \& Pollard, 1975).

Os valores de carga permanente positiva encontrados por Tessen \& Zauyah (1982) para oxissolos são pequenos, $10 \mathrm{mmol} \mathrm{kg}^{-1}$ enquanto para um Gibbsihumox, El Swaify \& Sayeg, (1975) obtiveram valores variando de +5 a -2 mmol kg${ }^{-1}$, dependendo da solução usada. Graças a esse fato, a carga permanente estrutural positiva é considerada desprezível nos solos dos trópicos.

\subsubsection{Cargas variáveis}

As cargas variáveis são a diferença entre moles de prótons e moles de íons hidroxila complexados pelos grupos funcionais de superficie e, conceitualmente, os prótons encontrados na parte difusa da dupla camada de cargas não são incluídos como carga variável (Sposito, 1989; 1992).

As fontes de carga variável em solos incluem óxidos e oxihidróxidos de $\mathrm{Fe}, \mathrm{Al}, \mathrm{Mn}$, Si e Ti, a matéria orgânica e arestas quebradas dos minerais de argila. 


\subsubsection{1 Óxidos hidratados}

Os principais óxidos e óxihidratados nos solos incluem os óxihidróxidos de ferro, alumínio, manganês, titânio e silício.

Quando os óxidos metálicos encontram-se suspensos na solução do solo, os íons metálicos próximos à superfície ou nas arestas quebradas tendem a coordenar com as moléculas de água ao invés de coordenarem com os grupos hidroxilas. Estas moléculas de água de superficie então tendem a perder ou ganhar prótons $\left(\mathrm{H}^{+}\right)$dependendo da concentração desses prótons na solução. Quando o $\mathrm{pH}$ é baixo, a superficie ganha um íon $\mathrm{H}^{+}$resultando num excesso de carga positiva e, quando o $\mathrm{pH}$ é alto as moléculas de água tendem a perder íons $\mathrm{H}^{+}$resultando num excesso de carga negativa (Bolan et al.,1999).

A carga originada da associação ou dissociação de prótons pode ser representada por:

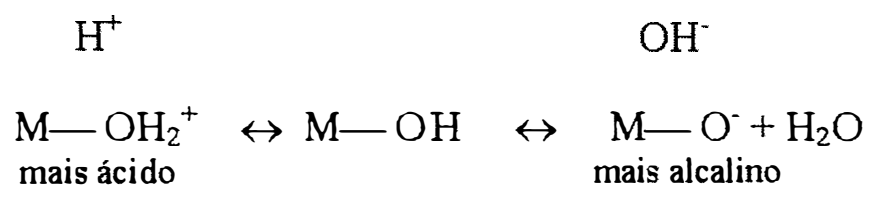

em que, $\mathrm{M}$, representa o metal coordenado ou o ín silício na superficie da argila. A intensidade da associação ou dissociação de prótons é determinada pela concentração desse íon próxima à superfície, pelo $\mathrm{pH}$ e pela concentração eletrolítica da solução. $\mathrm{O}$ pH em que a superficie encontra-se descarregada é conhecida como ponto de carga zero (PCZ).

Seguindo uma tendência na literatura, recentemente Sturnm (1992) e McBride (1994) fizeram uso dos conceitos de equilíbrio ácido-base e das constantes de dissociação ácida para descrever as reações de protonação e deprotonação das superficies minerais oxídicas e seus grupamentos funcionais da seguinte forma: 


$$
\mathrm{M}-\mathrm{OH}+\mathrm{H}^{+} \Leftrightarrow \mathrm{M}-\mathrm{OH}_{2}^{+}
$$

$$
\begin{aligned}
& \mathrm{M}-\mathrm{OH}_{2}^{+} \Leftrightarrow \mathrm{M}-\mathrm{OH}+\mathrm{H}^{+} \\
& \mathrm{K}_{\mathrm{a}_{1}}=\frac{\{\mathrm{M}-\mathrm{OH}\}\left[\mathrm{H}^{+}\right]}{\left.\mathrm{M}-\mathrm{OH}_{2}+\right\}} \mathrm{mol} / \mathrm{L} \\
& \mathrm{M}-\mathrm{OH}^{-} \Leftrightarrow \mathrm{M}-\mathrm{O}^{-}+\mathrm{H}^{+} \\
& \mathrm{K}_{\mathrm{a}_{2}}=\frac{\{\mathrm{M}-\mathrm{O}\}\left[\mathrm{H}^{+}\right]}{\{\mathrm{M}-\mathrm{OH}\}} \mathrm{mol} / \mathrm{L}
\end{aligned}
$$

onde: \{\} é a concentração da espécie de superfície em $\mathrm{mol} / \mathrm{L}$ de adsorvente sólido, [ ] é a concentração de solutos em mol/L, e $\mathrm{M}$ é um metal ou íon silício na estrutura do mineral em coordenação com oxigênio ou hidroxilas.

A natureza acídica dos grupamentos $\mathrm{OH}$ e por conseguinte as constantes de dissociação ácidas têm sido utilizadas a fim de explicar a variação do PCZ para os minerais.

Além dos óxihidróxidos cristalinos, os óxidróxidos microcristalinos e a alofana também desenvolvem carga variável. Suas cargas são mais fortemente dependente de $\mathrm{pH}$ do que a dos óxidos cristalinos. A alofana é um grupo de silicatos de alumínio hidratados com diferentes relações sílica/alumínio. Todas as alofanas são constituídas de materiais microcristalinos possuindo ligações $\mathrm{Si}-\mathrm{O}-\mathrm{Al}$. A alofana carrega carga negativa de superficie a $\mathrm{pH}$ elevado por meio 
da dissociação dos íons $\mathrm{H}^{+}$do grupo siloxano (三Si- $\mathrm{OH}$ ), e carrega uma carga positiva de superficie a $\mathrm{pH}$ baixo graças à associação de prótons com o grupo aluminol - (Al- OH) $(\mathrm{Yu}, 1997)$.

\subsection{Matéria orgânica}

A reatividade da matéria orgânica do solo, particularmente das substâncias húmicas, está relacionada às suas propriedades eletroquímicas, basicamente ao grau de acidez de seus grupos funcionais.

Um colóide é ácido em função do seu conteúdo de grupos funcionais contendo oxigênio. As substâncias húmicas comportarn-se como ácidos fracos polieletrólitos, isto é, ácidos fracos poliprotonados, levando-os a exibir um elevado poder tampão numa ampla faixa de $\mathrm{pH}$.(Stevenson, 1994).

A natureza química da acidez dos solos é melhor explicada pelos conceitos de ácido-base de Lowry \& Brönsted (1923) e de Lewis (1923). Segundo estes conceitos (Mahan, 1972), os primeiros autores definiram um ácido como uma substância que libera próton $\left(\mathrm{H}^{+}\right)$e uma base, como aquela substância que aceita próton. $\mathrm{O}$ segundo autor definiu um ácido como uma substância que pode receber um par de elétrons e, uma base, como aquela substância que pode doar um par de elétrons, para formar uma ligação covalente. Portanto, para que uma molécula seja considerada um ácido, ela deve ser deficiente em elétrons e isso ocorre nos grupos funcionais das substâncias húmicas, tais como: $\mathrm{OH}, \mathrm{N}-\mathrm{H}, \mathrm{S}-\mathrm{H}$.

O grau de acidez ou força ácida de um colóide dependerá da natureza das estruturas associadas na molécula. A reatividade das substâncias húmicas é causada pelo seu alto conteúdo de grupos funcionais contendo oxigênio, por exemplo: álcool $\left(\mathrm{R}-\mathrm{CH}_{2} \mathrm{OH}\right)$, aldeído $(\mathrm{R}-\mathrm{CHO})$, carboxila (R-COOH), enol $(\mathrm{R}-\mathrm{CH}=\mathrm{CH}-\mathrm{OH})$, cetona $\left(\mathrm{R}-\mathrm{CO}-\mathrm{R}^{\prime}\right)$ etc (Stevenson, 1994). 
A dissociação do íon hidrogênio de cada grupo funcional é fortemente dependente do $\mathrm{pH}$ sendo que nenhuma fração da matéria orgânica do solo, com carga positiva líquida, tem sido encontrada a valores naturais de $\mathrm{pH}$. Entretanto, espécies orgânicas [R] ligadas a grupos funcionais $\mathrm{OH}$ ou $\mathrm{NH}_{2}$ podem protonar gerando cargas positivas ( $\mathrm{R}-\mathrm{OH}_{2}{ }^{+}$e $\mathrm{R}-\mathrm{NH}_{3}{ }^{+}$) (Bohn et al., 1979). Em geral, o grupo $\mathrm{OH}$ dos ácidos carboxílicos se dissocia mais facilmente do que os álcoois alifáticos ou aromáticos, e os compostos fenólicos são ácidos mais fortes do que a água ou álcoois, embora eles sejam mais fracos do que os ácidos carboxílicos. A maioria dos grupos funcionais ácidos se dissociam entre valores de $\mathrm{pH} 5$ e 7 . A dissociação dos grupos carboxílicos e fenólicos produzem 85 a $90 \%$ da carga negativa das substâncias húmicas e corresponde a uma acidez de 300 a $1700 \mathrm{cmol} \mathrm{kg}^{-1}$ (Raij \& Peech, 1972; Peixoto, 1997).

2.1.1.2.3 Arestas quebradas das camadas silicatadas.

A aresta quebrada da caulinita é o mais típico sítio de superficie de carga variável entre as camadas silicatadas. $\mathrm{O}$ desenvolvimento de carga variável nas arestas cristalinas da caulinita é representado como segue:

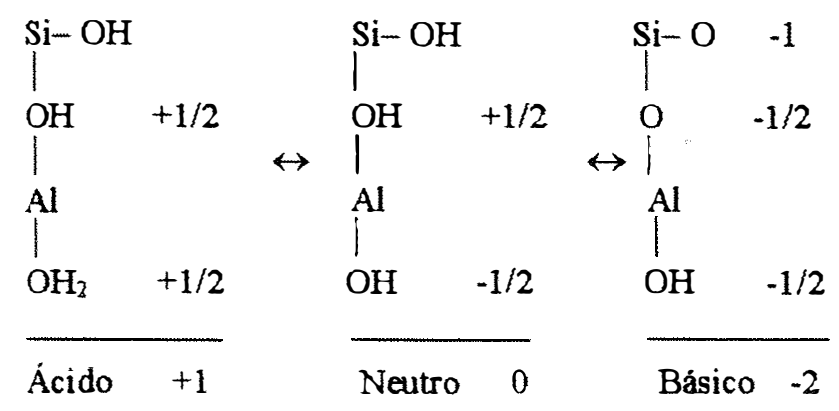


Dependendo do $\mathrm{pH}$ do ambiente, a carga pode ser neutra, positiva ou negativa. Quando neutra, cada um dos dois oxigênios do octaedro alumíniooxigênio liga a um hidrogênio, enquanto que ao mesmo tempo ele liga ao alumínio pela metade da ligação. Como um dos oxigênios também se liga ao silício, este oxigênio carregará meia carga positiva. De modo semelhante, outro oxigênio ligando ao alumínio carrega meia carga negativa. Neste caso, a carga líquida nas arestas da superfície é zero. Quando a caulinita está em meio ácido, o oxigênio liga-se ao alumínio, carregando a meia carga negativa aceita um próton e assim, torna-se a carregar com meia carga positiva, resultando numa unidade de aresta de superficie carregando uma carga positiva $(+1)$. Em condições alcalinas, uma unidade da aresta carregará duas cargas negativas devido à dissociação dos ions hidrogênio dos dois grupos hidroxílicos ligados ao silício.

Em minerais de argila do tipo $2: 1$ as arestas de camadas silicatadas pode também haver produção de cargas variáveis causada pela dissociação de hidrogênio ou pela adsorção de próton de grupos hidroxílicos expostos, das ligações quebradas. No entanto, essas cargas geralmente não se manifestam de forma marcante por esses minerais possuírem uma grande quantidade de carga permanente (Yu, 1997).

A vermiculita com hidroxilas entrecamadas (VHE) apresenta carga elétrica permanente originada da substituição isomórfica na estrutura da argila e carga elétrica variável na entrecamada do hidróxido de Al do mineral (Bamhisel \& Bertsch, 1989). A quantidade de cargas positiva e negativa do componente de carga variável altera-se com a mudança no $\mathrm{pH}$ ou na concentração eletrolítica da solução do solo (Uehara \& Gillman, 1981). 
2.1.1.3 Cargas geradas pela adsorção de cátions e ânions.

As cargas elétricas variáveis também podem originar-se por um processo em que um soluto torna ligado coordenadamente à superfície sólida e que não depende da carga de superfície pré-existente. Estas reações são chamadas de reações de adsorção (White \& Zelazny, 1986; Bolan et al., 1999). Há dois tipos principais de adsorção, a fisiosorção e a quimiosorção. Poucos são os processos de fisiosorção no solo com exceção da adsorção da água. A quimiosorção pode ser a adsorção não específica, para um elemento particular resultando de uma atração eletrostática de íon indiferente ou de uma adsorção específica.

Uehara \& Gillman (1981) distinguiram duas categorias de adsorção específica: (1) adsorção específica de alta afinidade e (2) adsorção específica de baixa afinidade. Ambos os casos podem ser descritos como reações de troca de ligantes da mesma forma que Mott (1981) descreveu, o que difere é o grau de incorporação do íon na superfície. A adsorção específica de baixa afinidade de cátions induz a uma carga negativa adicional pela dessorção de próton enquanto que, a adsorção específica de baixa afinidade de ânions induz à carga positiva adicional. A adsorção de cátions e ânions num processo de adsorção específica de alta afinidade resulta na inclusão do íon na superfície com transferência de sua carga para ela. Wada (1980), considera a adsorção não específica uma interação coulômbica de camada externa, enquanto que a adsorção específica envolve espécies adsorventes substituindo parte da camada interna de coordenação, por isso são chamados de complexação de esfera externa e de esfera interna, respectivamente.

Os processos de adsorção específica podem ser estudados numa variedade de técnicas. Os mais importantes métodos são a adsorção (ou dessorção), cinética química e análises de infravermelho. Com o desenvolvimento da termodinâmica e com o aperfeiçoamento dos métodos espectroscópicos, os mecanismos de ligação 
entre espécies químicas na solução aquosa tem sido melhor entendido (Stumm \& Morgan, 1981). A aplicação dos princípios da química de coordenação para explicar as propriedades de cargas funcionais de superfície dos colóides, bem como a interação entre os grupos funcionais de superficie e os eletrólitos na solução aquosa levou ao desenvolvimento da teoria de complexação de superficie semelhante à química de soluções aquosas (Sposito, 1984; Stumm, 1992). A adsorção é descrita em termos de um grupo de reações de complexação entre íons na solução aquosa e os grupos funcionais de superficie produzindo um plano bidimensional na interface sólido- líquido compreendendo: (1) complexos de esfera-interna quando não existe molécula de água entrepondo os grupos funcionais e o contra-íon ligante; (2) complexo de esfera-externa, onde existe a molécula de água entrepondo os grupos funcionais e o contra-íon ligante e (3) agrupamento de íons difusos, onde não há contato direto do íon solvatado com os grupos funcionais de superficie.

\subsection{Componentes de Carga Elétrica de Superfície}

As definições e as medições dos componentes de carga de superficie e pontos de carga zero, genericamente $\mathrm{PCZ}$, vêm se desenvolvendo continuamente (Parks \& Breuyn, 1962; Parks, 1965; Parker et al., 1979; Uehara \& Gillman, 1980, 1981; James \& Parks, 1982; McBride, 1989; Sverjensky, 1994) e há a necessidade de padronizar a nomenclatura e procedimentos experimentais para que facilite a comparação dos resultados obtidos nos diferentes trabalhos (Raij 1973 a, b; Gangaiya \& Morrison, 1987; Marcano-Martinez \& McBride, 1989; Razaq \& Tabatabai, 1990; Siqueira et al., 1990c; Sposito, 1992; Camargo \& Alleoni, 1996; Fontes, 1996). Atualmente, a terminologia conceitualmente aceitável define que os complexos de superficie e suas relações de carga permitem um balanço levando em consideração a lei da conservação que não 
requer nenhum modelo químico de superfície, como a teoria da dupla camada elérica (Sposito, 1989 a; 1992). Esse balanço de cargas se aplicaria a qualquer tipo de solo, tanto aos com predominância de minerais de carga permanente como àqueles com maioria dos minerais de carga variável, desde que apresentem uma interface com cargas elétricas (Fontes, 1996).

Quatro componentes de carga de superficie contribuem para a densidade de carga líquida total da partícula $\left(\sigma_{\mathrm{p}}\right)$. Primeiro, a densidade de carga estrutural permanente de superficie, $\sigma_{O}$, criada pelas substituições isomórficas nos minerais de argila do solo. Na realidade, estas substituições ocorrem tanto em minerais primários quanto em minerais secundários, mas elas produzem mesmo, carga negativa significativa nos aluminossilicatos do tipo 2:1 (Dixon \& Weed, 1989). Segundo, a densidade de carga de superficie protônica, $\sigma_{\mathrm{H}}$, é criada pelas diferenças entre os moles de prótons e os moles de íons hidróxidos complexados pelos grupos funcionais de superficie. Em seguida, a densidade de carga de superficie de complexos de esfera interna, $\sigma_{\mathrm{EI}}$, que resulta da carga líquida total dos íons, e envolve outros íons além de $\mathrm{H}^{+}$e $\mathrm{OH}$, que estão ligados na superficie por coordenação de esfera interna. Finalmente, a densidade de carga de superfície de complexos de esfera externa, $\sigma_{\mathrm{EE}}$, que resulta da densidade de carga líquida total dos íons, e envolve outros íons além de $\mathrm{H}$ e $\mathrm{OH}$, que são ligados na superficie por coordenação de esfera externa.

A equação geral do balanço de cargas pode ser expressa como a soma das diversas densidades de carga (Sposito 1981 ; 1984; 1989a; 1992) e a carga total da partícula pode ser representada matematicamente por:

$$
\sigma_{\mathrm{P}}=\sigma_{\mathrm{O}}+\sigma_{\mathrm{H}}+\sigma_{\mathrm{EI}}+\sigma_{\mathrm{EE}}
$$


Se $\sigma_{\mathrm{p}}$ é diferente de zero, há necessidade do seu balanceamento com a densidade de carga da dupla camada elétrica difusa, $\sigma_{D}$, que é igual em magnitude, mas de sinal contrário à carga total. A lei do balanço de carga pode ser então representada pela equação:

$$
\sigma_{0}+\sigma_{\mathrm{H}}+\sigma_{\mathrm{EI}}+\sigma_{\mathrm{EE}}=-\sigma_{\mathrm{D}}
$$

ou assim,

$$
\sigma_{\mathrm{p}}=-\sigma_{\mathrm{D}}
$$

Mais duas unidades de cargas podem ser derivadas, a densidade de carga de superficie intrínsica da partícula :

$$
\sigma_{\mathbb{N}}=\sigma_{0}+\sigma_{\mathrm{H}}
$$

e a densidade de carga de supericie da camada de Stern :

$$
\sigma_{\mathrm{S}} \equiv \sigma_{\mathrm{EE}}+\sigma_{\mathrm{EI}}
$$

Outro componente que pode ser operacionalmente definido é o excesso de carga superficial iônica específica relativa líquida, que para o caso do $\mathrm{LiCl}$, pode ser representado pela expressão:

$$
\Delta \mathbf{q}=\mathbf{q}_{\mathrm{Li}}^{+}-\mathbf{q}_{\mathrm{C} i}^{-} \equiv \sigma_{\mathrm{EI}}+\sigma_{\mathrm{EE}}+\sigma_{\mathrm{D}}
$$




\subsection{Métodos para medir as cargas de superfície}

Como já referido anteriormente, em estudos de cargas de superfície os solos têm sido tradicionalmente classificados com dois tipos de colóides bem conhecidos: (1) aqueles com superficie de carga constante, onde as cargas são originadas da substituição isomórfica de íons de diferentes valências dentro das estruturas cristalinas dos minerais de argila (Bolt, 1982) e (2) aqueles com superficie de potencial constante onde o potencial elétrico à superficie da partícula é apenas determinado pela atividade dos íons determinadores de potencial (idp) em solução (Bolt \& van Riemdijk, 1982). Estas classificações têm sido propostas com o objetivo de estabelecer relações matemáticas entre carga de superficie e potencial para interfaces que são (1) completamente polarizável ou (2) reversível aos íons determinadores de potencial. No primeiro caso, a carga de superficie é modelada como uma quantidade fixa, mas o potencial elétrico de superficie varia em função da concentração eletrolítica (potencial elétrico diminui com aumento da força iônica). No segundo caso, o potencial elétrico de superficie é considerado constante para uma dada atividade dos íons determinadores de potencial em solução, mas a carga de superficie varia em função da concentração eletrolítica (carga de superfície aumenta com o aumento da força iônica).

Em geral, solos de clima temperado, contendo grandes quantidades de minerais de argila com carga permanente, têm sido modelados como superfície de carga constante (Bolt, 1982), enquanto que, solos altamente intemperizados dos trópicos úmidos, dominados por óxidos de alumínio e ferro e caulinita, têm sido modelados como superficie de potencial constante (Raij \& Peech, 1972).

É possível quantificar os componentes de carga permanente e variável de um solo ao se aplicarem as definições operacionais que possibilitem derivar procedimentos experimentais (Charlet \& Sposito, 1987; Anderson \& Sposito, 1991, 1992; Sposito, 1992; Chorover, 1993; Chorover \& Sposito, 1993, 1995; 
Peixoto, 1995; Peixoto et al., 1995 a, b) que de fato estimem os efeitos da carga superficial na adsorção de ions-índice embora a própria carga superficial não esteja sendo medida.

Inúmeros trabalhos têm sido propostos para medir o comportamento das cargas superficiais das partículas do solo destacando-se os métodos eletrocinéticos, a titulação salina, a técnica de adição mineral, de adsorção iônica e da titulação potenciométrica. Os dois últimos apresentam uma facilidade operacional e medem atributos importantes para o estudo eletroquímico do solo, sendo que o método de adsorção iônica será utilizado no presente estudo.

\subsubsection{Medida da carga permanente}

O conhecimento da carga elétrica permanente $\left(\sigma_{0}\right)$, como componente de carga superficial das partículas do solo é fundamental para o entendimento e previsão do destino dos elementos químicos no solo. $O$ valor de $\sigma_{\circ}$ também é necessário para as determinações dos demais componentes de densidade de carga de superficie e dos pontos de carga zero dos solos (Sposito, 1992).

Anderson \& Sposito (1991) propuseram um método para determinar a carga estrutural permanente $\left(\sigma_{\circ}\right)$ que se fundamenta na alta seletividade que o íon $\mathrm{Cs}^{+}$tem para com os filossilicatos 2:1 em função da formação de complexos de esfera interna nos poros ditrigonais das superfícies de siloxanas desses minerais. Essa seletividade é aumentada no sistema onde o cátion trocador é $\circ \mathrm{Li}^{+}$e a secagem do material adsorvente aumenta a força de formação do complexo de esfera interna entre o $\mathrm{Cs}^{+} \mathrm{e}$ a carga estrutural mineral. Em seqüência à secagem, promove-se uma troca iônica com $\circ \mathrm{Li}^{+}(\mathrm{LiCl})$ para extrair o $\mathrm{Cs}^{+}$dos grupos funcionais hidroxila e por último remove-se o $\mathrm{Cs}^{+}$adsorvido por troca com $\mathrm{NH}_{4}^{+}$ do $\left(\mathrm{AcONH}_{4}\right)$ que tem a capacidade de penetrar nos poros ditrigonais das 
superfícies de siloxanas. Este método envolve apenas procedimentos de adsorção de metais (método do $\mathrm{Cs}^{+}$) sem qualquer participação de titulação potenciométrica.

Essa metodologia tem sido aplicada com muito sucesso por Anderson (1989), Anderson \& Sposito (1991), Chorover (1993), Chorover \& Sposito (1993, 1994, 1995), e em solos brasileiros por Fontes \& Sposito (1995) e Peixoto (1995). Anderson \& Sposito (1991) ao aplicarem esse método para medir as cargas estruturais nas amostras das camadas superficiais de dois alfissolos, um thermic Typic Haploxeralf e um thermic Natric Haploxeralf de San Diego-Califómia e de um oxissolo brasileiro, observaram que as quantidades das cargas variáveis e estruturais variaram respectivamente de 20,3 e $0,33 \mathrm{mmol}_{\mathrm{c}} \mathrm{kg}^{-1}$ no oxissolo, 35 e 65 mmol $_{\mathrm{c}} \mathrm{kg}^{-1}$ no thermic Typic Haploxeralf e de 39 e $43 \mathrm{mmol}_{\mathrm{c}} \mathrm{kg}^{-1}$ no thermic Natric Haploxeralf; observaram também, que os DRXs do oxissolo não detectaram presença de minerais 2:1.

Chorover \& Sposito (1995), utilizaram amostras superficiais de quatro solos cauliníticos brasileiros das regiões isopertérmica, todos solos de mata, sendo dois do estado do Amazonas, um nativo e o outro cultivado, o terceiro e o quarto solo, variação Una, eram de mata nativa dos estados de Rondônia e da Bahia, respectivamente. As cargas variáveis e estruturais obtidas foram de 60 e $21 \mathrm{mmol}_{\mathrm{c}} \mathrm{kg}^{-1}$, para o solo de floresta nativa, de 37 e $13 \mathrm{mmol}_{\mathrm{c}} \mathrm{kg}^{-1}$ para o solo cultivado do Amazonas; 31 e 8 mmol $_{\mathbf{c}} \mathrm{kg}^{-1}$ para o solo de Rondônia e de 55 e $15 \mathrm{mmol}_{\mathrm{c}} \mathrm{kg}^{-1}$ para o solo Una da Bahia.

Fontes \& Sposito (1995), ao utilizarem amostras de horizontes B de latossolos, com teores muito baixos de carbono orgânico, observaram que o método do $\mathrm{Cs}^{+}$permite detectar pequenas quantidades de minerais com carga permanente, muitas vezes em quantidades não detectáveis pela difração de raios $\mathrm{X}$. Os autores observaram que em latossolos vermelho escuros a $\mathrm{pH}$ em torno de 6,0 , quase a metade das cargas são função das cargas variáveis e um pouco mais 
da metade das cargas são devido às cargas permanentes mas, no latossolo vermelho amarelo as cargas variáveis representaram mais que cinco vezes as cargas permanentes.

Peixoto et al., (1995) utilizando amostras de horizontes $A_{1}, A_{2}$ e $B_{2}$ de latossolos sob florestas nativas na região sul do Brasil observaram que a matéria orgânica do solo foi uma fonte potencial de erro no método, dependendo principalmente do tipo e da quantidade do ín que estava naturalmente complexado nela. Os autores afirmam que, pela lógica do procedimento da amostragem e a natureza dos latossolos estudados foi possível detectar e isolar o efeito da matéria orgânica do solo na medição das cargas do solo possibilitando então, estimarem as cargas negativas variável e permanente do mineral e a carga negativa da matéria orgânica.

\subsubsection{Medida da carga variável}

\subsubsection{Adsorção iônica}

O método de adsorção iônica (Schofield, 1949) é baseado nas mudanças de retenção do íon com a variação da carga de superfície. Este método tem sido modificado e usado intensamente nos estudos de solos para medir os efeitos combinados de cargas permanente e variável como por exemplo, os trabalhos de Raij \& Peech, (1972); Espinoza et al., (1975); Gillman \& Uehara, (1980); Bolan et al., (1986); Naidu, et al., (1990).

Esta técnica envolve a saturação dos sítios de superficie do solo com um cátion e ânion adsorvidos não especificamente por meio do equilíbrio com uma solução eletrolítica contendo íons índices indiferentes. A quantidade de cátions e ânions pode ser calculada diretamente por deslocamento subseqüente com um 
eletrólito contendo íons adsorvidos especificamente ou indiretamente pela medida da concentração dos íons remanescentes na solução do solo.

A utilidade deste método depende da escolha de um eletrólito apropriado, os mais usados são $\mathrm{NaCl}, \mathrm{CaCl}_{2}$ e $\mathrm{MgSO}_{4}$, que substituirá todos os íons adsorvidos na superfície sem que haja formação de complexos de esfera interna (Sposito, 1981, 1984). Diferentes eletrólitos resultarão em diferentes valores para a carga de superfície, mas de acordo com Sposito (1984), se o eletrólito e as condições experimentais forem semelhantes às naturais, o resultado da carga de superfície será de uso prático.

\subsubsection{Titulação Potenciométrica}

O método da titulação potenciométrica foi introduzido por Raij \& Peech (1972) no estudo de solos. Este método é usado para medir a carga de superfície líquida protônica $\left(\sigma_{\mathrm{H}}\right)$ e é reservado para analisar apenas o PCZ (Schulthess \& Sparks, 1986) em que, o pH de uma suspensão é modificado em pequenas adições de volumes conhecidos de ácido ou base de diferentes forças iônicas. A cada adição de ácido ou base, o pH é medido a fim de determinar a quantidade de íons $\mathrm{H}^{+}$e $\mathrm{OH}$ remanescente na solução (Bolan, et al., 1999). A diferença entre o número de prótons medidos na solução branco e o número medido na solução sobrenadante representa os prótons complexados pelos sítios de superficie (Anderson. 1989). A quantidade de íons $\mathrm{H}^{+}$e $\mathrm{OH}^{-}$adsorvidos pelo solo a um determinado valor de $\mathrm{pH}$ é considerada como parte de carga de superficie positiva e negativa, respectivamente naquele $\mathrm{pH}$.

Assim, são traçadas várias curvas de carga (variação da carga líquida versus $\left.\mathrm{pH}(\partial \sigma / \partial \mathrm{pH})_{\mathrm{T}}\right)$ à várias forças iônicas, o valor de $\mathrm{pH}$ onde essas curvas 
interceptarem é o ponto de efeito salino nulo (PESN) do componente carga variável. Conforme mencionado, os estudos de química de superficie de solos brasileiros têm se concentrado na aplicação do método da titulação potenciométrica proposto por Raij \& Peech (1972) e modificado por Uehara \& Gillman (1981) para a determinação do PCZ, isto é, PESN sendo utilizado por Siqueira et al., (1990 a, b, e c), Pérez et al., (1993); Chaves \& Trajano (1992); Alleoni, (1992) e Alleoni \& Camargo (1994).

No entanto, o PCZ determinado por titulação é o ponto de carga protônica líquida zero (PCPLZ), um valor de $\mathrm{pH}$ em que a densidade de carga de superficie protônica líquida é zero $\left(\sigma_{\mathrm{H}}=0\right)$, já que por definição $\left.\operatorname{PESN}(\partial \sigma / \partial \mathrm{pH})_{\mathrm{T}}\right)$ não é PCZ. O PCPLZ depende da concentração da superficie ionizável do grupo funcional e da composição da fase solução. O PCPLZ é o PCZ mais importante para os solos que contêm tanto carga variável quanto a permanente,porque ele é o PCZ em que a contribuição de $\sigma_{\mathrm{H}}$ é considerado separadamente da $\sigma_{\mathrm{O}}$ (Bolan et al., 1999).

\subsubsection{Método combinado}

Em recentes pesquisas feitas por Sposito e colaboradores (Charlet \& Sposito, 1987; Anderson \& Sposito, 1992; Chorover, 1993) foram desenvolvidas medições simultâneas de propriedades macroscópicas apropriadas em solos brasileiros como, por exemplo, a adsorção não específica de íons e titulação potenciométrica, associadas com uma descrição química mecanística (teoria de complexação de superficie) e considerando-se as propriedades de carga permanente e variável em oxissolos dando origem ao método combinado. Este método, facilita a medição simultânea da densidade de carga superficial protônica 
$\left(\sigma_{\mathrm{H}}\right)$ e adsorção de cátion e ânion $\left(\mathrm{q}^{+}, \mathrm{q}^{-}, \Delta \mathrm{q}\right)$ para determinar PCPLZ e PESN (Charlet, 1986; Charlet \& Sposito, 1987, 1989). Este procedimento foi uma modificação do método clássico de Schofield aplicado por Raij \& Peech (1972). Anderson (1989) e Anderson \& Sposito (1991) juntaram este procedimento com o método desenvolvido para analisar a quantidade de carga estrutural permanente em argilas do tipo $2: 1\left(\sigma_{\circ}\right)$.

Recentemente o método combinado tem sido utilizado por Anderson (1989), Chorover \& Sposito (1995), Polubesova et al., (1995) e para oxissolos brasileiros por Peixoto (1995), Peixoto et al., (1995b) e Fontes \& Sposito (1995). Peixoto et al., (1995a, b) que consideram que a metodologia precisa ser melhorada tanto na medição da carga permanente $\left(\sigma_{\mathrm{O}}\right)$ quanto na medição de $\sigma_{\mathrm{H}} \mathrm{e}$ $\Delta$ q. Segundo esses autores, os problemas encontrados na adsorção iônica referem-se predominantemente à complexação do $\mathrm{Cs}^{+}$pela matéria orgânica na determinação do $\sigma_{\circ}$. Por ourro lado, o método da titulação potenciométrica, seria mais susceptível a erros, em virtude de reações secundárias onde as correções da hidrólise do alumínio podem exagerá-los ainda mais. Mas os autores ainda salientam que caso os valores extremos de $\mathrm{pH}$ sejam evitados, esses problemas podem ser minimizados.

\subsection{Conceito de ácidos e bases duros e moles (HSAB) de Lewis.}

Quase todas as reações químicas, incluindo as reações de troca iônica, podem ser descritas como reações de ácido-base de Lewis. Um ácido de Lewis pode ser qualquer espécie química que empregue um orbital eletrônico vazio ao iniciar uma reação, enquanto que uma base de Lewis pode ser qualquer espécie química que utilize um orbital eletrônico duplamente ocupado ao iniciar uma 
reação química (Berton, 1989). Devido à abrangência desta definição tem havido várias tentativas em classificar ácidos e bases de Lewis em categorias com relação ao seus comportamentos.

Pearson (1963), incluiu o conceito de ácidos e bases de Lewis como duro ou mole princípio HSAB do inglês Hard-Soft-Acid and Base. Algumas das características usadas para classificar ácidos e bases de Lewis como duro e mole são as seguintes: 1) um ácido de Lewis é considerado duro quando tem um tamanho relativamente pequeno com uma alta carga positiva, alta eletronegatividade, baixa polarizabilidade, possuem os elétrons mais externos apresentando uma dificuldade relativa de serem excitados para estados de energia mais elevado e de dificil redução; 2) ácidos moles são geralmente de tamanho relativamente grande com uma baixa carga positiva, baixa eletronegatividade , alta polarizabilidade, possuem os elétrons mais externos facilmente excitáveis sendo comumente os do orbital $\mathrm{d}$, e de fácil redução; 3) uma base dura usualmente tem alta eletronegatividade, baixa polarizabilidade e são de difícil oxidação e não possui orbitais eletrônicos vazios de baixa energia; 4) base mole apresenta baixa eletronegatividade, alta polarizabilidade e é de dificil oxidação.

Em geral, o hidrogênio, os elementos químicos dos grupos IA e ПA e todos os cátions metálicos de interesse na solução do solo são ácidos de Lewis, enquanto que as bases de Lewis incluem a água, os oxiânions do tipo $\mathrm{OH}-, \mathrm{O}^{2-}$, $\mathrm{COO}^{-}, \mathrm{CO}_{3}^{2-}, \mathrm{ROH}, \mathrm{SO}^{2-}$ e $\mathrm{PO}_{4}^{3-}$ e radicais orgânicos doadores de elétrons contendo N, S e P (Sposito, 1981).

Conhecendo a dureza ou moleza de várias espécies num sistema aquoso, a estabilidade dos complexos formados entre espécies pode ser predita pelo princípio $\mathrm{HSAB}$. De acordo com este princípio, as reações para a formação de complexos obedecem à seguinte regra: Ácidos duros tendem associar com bases duras e ácidos moles com bases moles (Pearson,1963). 
O possível uso do princípio HSAB para descrever reações de seletividade de troca iônica no sistema solo surgiu de observações experimentais que substâncias trocadoras de íons são seletivas para íons específicos em equilibrio com soluções multieletrolíticas (Sullivan, 1977).

Estas reações podem ser caracterizadas qualitativamente pelo princípio HSAB a partir da obtenção da estimativa numérica de moleza. Escalas empíricas têm sido usadas para quantificar a moleza dos ácidos e bases de Lewis como, a de Misono et al, (1967) e a de Ahrland (1968). A escala de Misono et al., (1967) é a mais usada e assume-se que moleza é a tendência de um íon metálico em formar uma ligação dativa $\pi$. Um parâmetro moleza é então calculado como uma função do potencial de ionização, da carga do íon metálico e de seu raio iônico. A escala empírica de moleza de Misono tem uma relação direta com as definições de Pearson (Tabela 1) e tem sido usada para descrever a seletividade de troca catiônica de minerais do solo e de ácidos húmicos (Sullivan, 1977; Sposito, $1981)$.

Tabela 1- Moleza do Íon Metálico* (adaptado de Sullivan, 1977).

\begin{tabular}{|c|c|c|c|c|c|}
\hline \multicolumn{2}{|c|}{$\begin{array}{l}\text { Estado de Oxidação } \\
\qquad+1\end{array}$} & \multicolumn{2}{|c|}{$\begin{array}{l}\text { Estado de Oxidação } \\
+2\end{array}$} & \multicolumn{2}{|c|}{$\begin{array}{l}\text { Estado de Oxidação } \\
+3\end{array}$} \\
\hline Íon Metálico & Moleza & Íon Metálico & Moleza & Ín Metálico & Moleza \\
\hline $\mathrm{H}$ & 1 & $\mathrm{Mg}$ & 0.87 & $\mathrm{Al}$ & 0.70 \\
\hline $\mathrm{Li}$ & 0.36 & $\mathrm{Ca}$ & 1.62 & In & 2.24 \\
\hline $\mathrm{K}$ & 0.92 & $\mathrm{Sr}$ & 2.08 & $\mathrm{Fe}$ & 2.37 \\
\hline $\mathrm{Na}$ & 0.93 & $\mathrm{Zn}$ & 2.34 & $\mathrm{La}$ & $2.45 f$ \\
\hline $\mathrm{Rb}$ & $2.27^{2}$ & $\mathrm{Ba}$ & 2.62 & Co & 2.56 \\
\hline $\mathrm{Cs}$ & 2.73 & $\mathrm{Ni}$ & 2.82 & $\mathrm{Ti}$ & 3.23 \\
\hline $\mathrm{Cu}$ & 3.45 & $\mathrm{Cu}$ & 2.89 & & \\
\hline \multirow[t]{6}{*}{$\mathrm{Ag}$} & 3.99 & $\mathrm{Mn}$ & 3.03 & & \\
\hline & & $\mathrm{Cd}$ & 3.04 & & \\
\hline & & $\mathrm{Fe}$ & 3.09 & & \\
\hline & & $\mathrm{Sn}$ & 3.17 & & \\
\hline & & $\mathrm{Pb}$ & 3.58 & & \\
\hline & & $\mathrm{Hg}$ & 4.24 & & \\
\hline
\end{tabular}

* a moleza aumenta à medida que os valores numéricos aumentam.

1 a moleza do ion H não pode ser calculada pela equação de moleza de Misono.

${ }^{2}$ valores calculados por Sullivan (1977) utilizando a equação de moleza de Misono. 


\subsection{Seletividade catiônica}

No solo, os cátions não são adsorvidos com a mesma força pelas cargas negativas dos colóides. Essa reação diferencial do solo tem sido explicada pelas variabilidades do tamanho dos cátions de mesma valência, nas formas de distribuição das cargas na superficie dos colóides e na estrutura dos sítios de troca onde os íons são adsorvidos (Bolt, 1967). O termo seletividade de troca de íons no solo é utilizado para expressar a relação entre os íons na superfície do colóide e os íons na solução.

A seletividade catiônica é a medida da afinidade relativa pela superficie por diferentes cátions. Teoricamente, ela depende das propriedades dos grupos funcionais e natureza dos cátions adsorvidos, com a água intermediando esse processo. Um estudo de seletividade de cátion fornece a chave para entender a interação entre o cátion e a superficie da água. Praticamente, a seletividade catiônica é um indício para o entendimento do transporte de soluto no solo e a disponibilidade dos solutos para os organismos vivos. Daí considerar-se, a seletividade catiônica um dos aspectos mais importantes na química de superfície dos solos (Xu \& Harsh, 1990 a, b).

A seletividade de troca de íons depende do mineral de argila e da matéria orgânica do solo. Em geral, os minerais do solo apresentam maior atração de superficie pelos cátions menos hidratados e os compostos orgânicos pelos cátions polivalentes, principalmente quando os grupos carboxílicos estão ligados por átomos de carbono adjacente (Loyola \& Pavan, 1989). A afinidade dos minerais de argila e do ácido húmico pelos cátions metálicos aumenta com o aumento dos valores do parâmetro de moleza de Misono. Isto indica que sítios de superfície sobre estes adsorventes comportam-se como bases moles de Lewis (Sullivan, 1977), ou pelo menos eles são bases mais moles que a água. 
Numerosas investigações acerca da seletividade catiônica de argilas do solo e resinas de troca iônica têm sido feitas (Bruggenwert \& Kamphorst, 1982). Para cátions alcalinos em montmorilonita (Krishnamoorthy \& Overstreet, 1949), matéria orgânica do solo (Wiklander, 1964) e resinas trocadoras de íons do tipo ácido forte, a seletividade de cátions alcalinos segue a série liotrópica: $\mathrm{Li}^{+}<\mathrm{Na}^{+}$ $<\mathrm{K}^{+}<\mathrm{Rb}^{+}<\mathrm{Cs}^{+}$freqüentemente referida como uma seqüência normal de seletividade .

É bem estabelecido que minerais de argila 2:1 têm alta afinidade por $\mathrm{Cs}^{+}$ em relação a outros cátions do Grupo IA. Além disso, uma seqüência de seletividade (o inverso da série liotrópica) de forma normal $\mathrm{Cs}^{+}>\mathrm{Rb}^{+}>\mathrm{K}^{+}>\mathrm{Na}^{+}$ $>\mathrm{Li}^{+}$tem geralmente sido observada em amplos estudos concernentes à retenção de íns em minerais de carga permanente (Schulz et al., 1960; Coleman et al.,1963 a \& b; Eliason, 1966; Sawhney, 1966, 1970, 1972; Gast, 1972; Bruggenwert \& Kamphorst, 1982; Evans et al., 1983; Brouwer et al., 1983; Comans et al., 1991). Na ausência de formação de complexo solúvel, como é o caso dos cátions do Grupo IA em solução aquosa, a seqüência de seletividade para íons monovalentes não é explicada pela teoria da dupla camada e sugere uma outra direção na tendência destes íons interagirem quimicamente com a superficie sólida (Bolt, 1982).

Para racionalizar as seqüências de seletividade, vários modelos têm sido propostos: modelo de hidratação catiônica (Gast, 1977; Bohn et al.,1979; Cotton \& Wilkinson, 1980), modelo de força do campo aniônico (Eisenman, 1962; Eberl, 1980); modelo do arranjo e quebra de estrutura (Kinniburg \& Jackson, 1981) e o princípio de HSAB (Pearson, 1963; Sullivan, 1977; Sposito, 1984; Xu \& Harsh, $1990 \mathrm{a}, \mathrm{b})$.

Os três primeiros modelos incluem uma ou mais das seguintes limitações: (1) consideram somente interações puramente eletrostática entre cátion e superficie e assim, podem predizer seqüências de seletividade somente para 
interações ácido duro/ base dura; (2) não levam em consideração os complexos de esfera interna e (3) falham áo considerar a seqüência de seletividade que são inversa ou parcialmente inversa à série normal de seletividade. Já o modelo que baseia no princípio HSAB é indicativo de previsão da seletividade catiônica. A aplicação quantitativa com base neste princípio foi apresentada por Xu \& Harsh (1990 a, b) para sistemas puros de argilominerais (vermiculita, esmectita), oxihidróxidos $\left(\mathrm{SiO}_{2}\right.$ gel, $\left.\mathrm{Zr}(\mathrm{OH})_{4}\right)$, e resinas trocadoras a fim de dar subsídios na aplicação futura desse modelo para todos os solos e cátions polivalentes.

Neste modelo, os autores incluíram valores teóricos da eletronegatividade absoluta, e das espécies químicas de absoluta moleza, além de dois parâmetros ajustáveis $(\alpha$ e $\beta)$ que estão relacionados às características de superficie do trocador. A eletronegatividade absoluta leva em conta a contribuição da interação eletrostática e determina se uma espécie química (cátion ou superficie) é um doador ou receptor de elétrons enquanto que, absoluta moleza, considera a contribuição da interação covalente e determina a facilidade do número de elétrons e a distribuição eletrônica de mudar no espaço eletrônico. Estes valores teóricos possibilitam estimar a seqüência de seletividade por meio das contribuições de seletividade iônica resultante das interações eletrostáticas e covalente.

Os autores observaram que em argilominerais 2:1 a dureza da superficie aumenta com o número de substituições isomórficas que ocorrem na camada tetraédrica e na densidade de carga originada dessa substituição e, a formação de complexos (interação covalente) ocorre se houver diferença na eletronegatividade absoluta entre cátion e superficie ou se a superficie for muito dura.

A seletividade aumenta com o aumento do número atômico para ions monovalentes e isto tem sido observado em muitas resinas trocadoras de íons ácidos fortes e óxidos metálicos de ácidos fortes de hidrogênio (Kinniburgh \& Jackson, 1981). As superficies dos óxidos e da resina trocadora são consideradas 
mais moles que o mineral $2: 1$, porque essas superfícies estão relacionadas à tendência do próton em dissociar ou, ao PCPLZ. A dissociação protônica pode ser vista como a competição, por íons $\mathrm{H}$, entre a água e os grupos funcionais de superficie. O próton é uma ácido duro de Lewis e prefere coordenar com uma base dura de Lewis, como a água (Pearson, 1963, 1968). O PCPLZ do $\mathrm{Zr}(\mathrm{OH})_{4}$ é alto $\left(11,3\right.$, Park ,1967) enquanto que o de $\mathrm{SiO}_{2}$ é baixo (1,8-3,5 Kinniburg \& Jackson, 1981) consequentemente, o primeiro óxido é uma superficie mais dura em relação ao segundo nos quais, prevalece respectivamente, interações eletrostáticas e covalentes.

Esta seqüência de seletividade é explicada qualitativamente pela interação eletrostática entre o ín hidratado e os grupos funcionais de superficie; íns com menor raio de hidratação $\left(\mathrm{Cs}^{+}\right)$aproximam-se da superficie muito intimamente e podem estar sujeitos à grande distorção das suas águas de hidratação e assim, estarão retidos mais fortemente por meio das forças coulômbicas. Entretanto, a reversão das seqüências de seletividade da ordem nomal tem sido observada em alguns ácidos fracos de superficie como por exemplo, $\mathrm{Zr}(\mathrm{OH})_{4}, \mathrm{TiO}_{2}, \mathrm{Fe}_{2} \mathrm{O}_{3}$ (Berube \& Bruyn, 1968; Britz \& Nancollas, 1969; Kinniburgh \& Jackson, 1981).

Para uma descrição quantitativa da seletividade catiônica utiliza-se o coeficiente de seletividade o qual fomece uma medida quantitativa e experimentalmente acessível de uma troca binária para as condições na qual o experimento é executado. Este coeficiente pode ser usado como um índice para comparar a afinidade relativa de vários trocadores por cátions específicos.

Bruggenwert \& Kamphorst (1979) compilaram alguns coeficientes de seletividade para reações de troca catiônica para determinados minerais de argila e alguns outros componentes do solo. Em geral, as reações de troca $\mathrm{Li} \rightarrow \mathrm{Cs}$ e $\mathrm{Na}$ $\rightarrow$ Cs tem $K_{\text {exc }}$ que variam de 15 a 180 minerais de argila do tipo 2:1 dependendo da composição do sistema. A seletividade medida pela média de um coeficiente é claramente operacional e depende da fração molar do íon adsorvido 
preferencialmente. A sorção altamente seletiva de $\mathrm{Cs}^{+}$em minerais de argila 2:1 tem sido observada em numerosos estudos e é resultado da complexação de esfera interna do $\mathrm{Cs}^{+}$com sítios da superfície ditrigonal destes adsorventes (Coleman et al., 1963a; Eliason, 1966; Gast, 1972; Sawhney, 1972; Lim et al., 1980; Bruggenwert \& Kamphorst, 1982; Brower et al., 1983; Anderson \& Sposito, 1991 ; Comans et al., 1991 ; Chorover, 1993; Peixoto, 1995).

Investigações espectroscópicas indicam que $\mathrm{OCs}^{+}$é adsorvido em ambientes de superficies múltiplas de seletividade diferentes em minerais de argila 2:1 (Weiss \& Altner, 1990; Berstch \& Hunter, 1993). A seletividade para $\mathrm{Cs}^{+}$é elevada quando o íon trocador é o $\mathrm{Li}^{+}$, em razão da sua grande energia de hidratação (Xu \& Harsh, 1992).

Com base nas discussões anteriores, é razoável concluir que as reações de complexação de superficie são responsáveis pelas as seqüências de seletividade monovalente normal observada para sólidos do solo. Estas reações de complexação são mais importantes para a carga permanente dos minerais 2:1, uma observação qualitativamente consistente com o princípio do HSAB tão aplicada para os grupos funcionais siloxanos (Chorover, 1993). Fatores eletrostáticos provavelmente desempenham um papel importante, especialmente para ácidos fracos. Esta seqüência de seletividade normal tem sido observada em poucos estudos para constituintes da matéria orgânica sólida (Stevenson, 1982). Entretanto, a magnitude da seletividade relacionada àquela observada em minerais com carga permanente, parece ser pequena.

Estas observações sugerem que a adsorção de $\mathrm{Cs}^{+}$pode ser empregada sob condições apropriadas, como uma prova dos sítios siloxanos carregados nas superfícies das argilas de carga permanente em sistemas heterogêneos como ocorrem em solos (Anderson \& Sposito, 1991). 


\subsection{Reações do césio em sítios com carga permanente e em sítios com superfícies ionizáveis.}

As reações de césio com solos e argilominerais têm sido estudadas com uma grande variedade de métodos há três décadas e estes estudos têm sido focalizados do ponto de vista ambiental quanto à adsorção de quantidades traços das espécies ${ }^{135} \mathrm{Cs}$ e ${ }^{137} \mathrm{Cs}$. Revisões de literatura referente à adsorção de césio foram feitas por Tamura (1964) e Sawhney (1972) sem contudo, darem ênfase aos mecanismos de adsorção de césio tanto nos sítios com carga permanentes quanto nos sítios com carga ionizáveis e, dentro do contexto são envolvidas reações de complexação de superfície.

Têm havido relatos quanto à fixação do íon césio por filossilicatos 2:1 (Schulz, et al., 1960; Nishita et al., 1962; Coleman et al., 1963a; Sawhney, 1966, 1972) e adsorção seletiva, ou seja descrição da causa da reação termodinamicamente reversível da adsorção de césio sobre a montmorilonita (Gast, 1969) e sobre o deslocamento de cátions monovalentes por césio em vermiculitas (Coleman et al., 1963a). A preferência dos filossilicatos 2:1 pelo íon césio aumenta a medida que aumenta a densidade de carga de superficie (Anderson, 1989), isto porque este íon perde sua camada de solvatação quando é adsorvido em minerais como a ilita ou vermiculita.

Muitos resultados experimentais têm mostrado indícios que os íons césio formam complexos de esfera interna com ilita e vermiculita e são parcialmente hidratados quando adsorvidos na montmorilonita (Anderson, 1989). Difratogramas de raios X obtidos por Barshad (1950), revelaram que os íons césio formam complexos de esfera interna com a vermiculita em amostras secas ao ar enquanto que, em suspensões de montmorilonita esses íons aparentemente formam complexos de superficie apenas nos sítios entrecamadas. 
A adsorção de césio em sítios de superfície fracamente ácidos tem sido menos estudada que as reações relacionadas com sítios de carga permanente, e o mecanismo de adsorção do Cs pela caulinita, óxihidróxidos e matéria orgânica é menos conhecido (Anderson, 1989). A caulinita apresenta grande afinidade pelo íon césio em relação ao íon sódio. Este mineral tem uma menor afinidade por $\mathrm{Cs}^{+}$ que os filossilicatos do tipo 2:1 (Anderson, 1984, Schulz et al., 1960; Coleman et al., 1963b; Tamura, 1964; Sawhney, 1972). As reações de troca de $\mathrm{M}^{\mathrm{Z}^{+}}-\mathrm{Cs}^{+}$na caulinita são controladas pela valência, energia de hidratação e, pelo cátion competidor. Este fato indica que $\mathrm{Cs}^{+}$não forma complexos de superfície de esfera interna com sítios ionizáveis na caulinita. Tem sido sugerido que a preferência da caulinita por $\mathrm{Cs}^{+}$é causada pelas impurezas de filossilcatos 2:1 (Lim et al., 1980), e é possível que uma menor quantidade de carga permanente possa ser responsável pela alta seletividade $\mathrm{Na}^{+} \rightarrow \mathrm{Cs}^{+}$da caulinita quando a fração molar do $\mathrm{Cs}^{+}$adsorvido é baixa (Anderson, 1989).

A seletividade $\mathrm{Na}^{+} \rightarrow \mathrm{Cs}^{+}$em géis de óxidos de ferro depende do método usado para preparar o gel (Misak et al., 1988), mas em todos os casos a seletividade $\mathrm{Na}^{+} \rightarrow \mathrm{Cs}^{+}$é menor do que em filossilicatos do tipo 2:1 ou mesmo em caulinita. Musick \& Ristic (1988), encontraram que $\mathrm{Cs}^{+}$é adsorvido não especificamente em hematita, magnetita e óxihidróxido amorfo de $\mathrm{Fe}(\mathrm{III})$. Em géis de óxidos de $\mathrm{Fe}$ e em matéria orgânica, a reversão de seletividade pode ocorrer na medida que aumenta a força iônica (Wiklander, 1964; Misak et al., 1988). Dados para troca de Cs em matéria orgânica são limitados, mas sabe-se que $\mathrm{o}^{+}{ }^{+}$desloca mais $\mathrm{K}^{+}$do humato-K do que alguns cátions metálicos alcalinos (Stevenson, 1994). 


\subsection{Efeito da remoção dos óxidos de ferro e da matéria orgânica no comportamento das cargas elétricas.}

A fase sólida do solo é composta por minerais de argila, óxidos, matéria orgânica e às vezes sais solúveis. Os três primeiros componentes coexistem intimamente nos solos de modo complexo e podem ter influências mútuas. Para solos com carga variável, diversos óxidos, tais como os óxihidróxidos de ferro, alumínio, manganês, e titânio, têm significado especial graças às suas quantidades elevadas e a grande variabilidade de sua carga de superfície, que causam a diferença básica nas propriedades de carga de superficie entre solos com carga variável e com carga constante (Yu, 1997).

\subsection{1 Óxidos de ferro}

Os óxidos de ferro influem no comportamento de cargas dos solos particularmente nos oxissolos altamente intemperizados dos trópicos onde eles formam uma parte significativa da fração fina. Em solos com carga variável os óxidos de ferro são os principais materiais na produção de carga positiva de superficie e isto se deve aos grupos $\mathrm{Fe}-\mathrm{OH}$ na sua superficie que podem adsorver íons $\mathrm{H}^{+}$da solução quando o $\mathrm{pH}$ é menor que seu $\mathrm{PCZ}$.

Como os óxidos de alumínio e de ferro são conhecidos por terem valores de PCZ maior do que 7,0, altos conteúdos destes óxidos elevaria o PCZ do solo. Sabe-se também, que os óxidos não cristalinos têm valores de PCZ maiores que os óxidos cristalinos (Parks, 1965). A contribuição das diferentes formas de óxidos de ferro para a carga positiva difere muito e esta diferença está relacionada às formas dos óxidos de ferro, cabendo ao óxido de ferro amorfo gerar grande quantidade de carga positiva em relação à forma cristalina (Yu, 1997). Em vários 
solos tanto o conteúdo quanto a forma dos óxidos de ferro são diferentes, mas Cornell \& Schwertmann (1996) afirmam que a extensão desta contribuição é função mais de suas concentrações e da sua superfície específica do que do tipo do óxido.

As variações das cargas positiva e negativa em relação ao $\mathrm{pH}$ antes e depois de remover os óxidos de ferro têm sido objeto de estudo por pesquisadores como Sumner (1962); Desphande et al., (1964); Greenland \& Oades (1968); ElSwaify (1976), Fey \& Le Roux (1976), Rengasamy \& Oades (1977a , b; 1978); Sakurai et al., (1991), Itami et al., (1996) e outros. Estudos sobre a remoção de óxidos livres em solos com pigmentação vermelha mostraram que os íons ferro que se encontravam presentes como partículas discretas, ao serem removidos, não causaram um aumento das cargas negativas não alterando portanto, as propriedades físico-químicas do solo (Desphande et al., 1964; Tweneboah et al., (1967). Enquanto que os óxidos de alumínio pôde estar presentes como camadas absorvidas de superficie finamente divididas carregando cargas positivas. Greenland \& Oades (1968) e Rengasamy \& Oades (1977) também confirmaram que os hidróxidos de ferro ocorrem como partículas discretas na caulinita.

Sumner (1962), ao deferrificar amostras de solos com ditionito, observou completa remoção dos óxidos de ferro e atribuiu a redução das cargas positivas aos óxidos de alumínio como sua principal fonte, sendo que esse tratamento pode ou não remover materiais geradores desse tipo de carga. $O$ mesmo efeito nas características das cargas foi observado por Itami et al., (1996).

El-Swaif (1976) e Rengasamy \& Oades (1978) confirmaram as observações de Sumner (1962) quando verificaram que os hidróxidos de alumínio amorfos exibem cargas positivas na região ácida e que bloqueavam as cargas negativas permanentes dos argilominerais. Yu (1997) observou redução das cargas positivas em solos com carga variável e afirma que este fato coincidiu com o conteúdo de óxidos de ferro livre removido, sugerindo que estes óxidos sejam 
seus principais geradores e que uma porção considerável destes óxidos combina com os minerais de argila resultando um efeito bastante complexo sobre as cargas do solo.

Uma parte dos óxidróxidos de ferro encontram-se combinados com minerais de argila na forma de recobrimento, o que também influi na quantidade de carga (Parfitt, 1980; Yu, 1997). Freqüentemente estes recobrimentos consistem de materiais amorfos liberados dos minerais primários pelo intemperismo ou da deposição de material translocado e depositado. $\mathrm{Na}$ presença destes revestimentos, a carga de superfície gerada na interface entre as fases sólida e líquida dependerá não somente da carga de seu mineral, mas também da carga desenvolvida pelos materiais amorfos revestidor (Hendershot \& Lavkulich, 1983).

Alguns relatos de recobrimento por óxihidróxidos são freqüentes, mas poucas são as evidências diretas da presença de tais recobrimentos em sistemas naturais (Greenland \& Mott, 1978). Micrografias eletrônicas de solos do Sul da Austrália mostraram que partículas de argilas são recobertas com uma substancial crosta de silício, provavelmente alumino-sílica para ilita pobremente ordenada (Wada \& Greenland, 1970). Jones \& Uehara (1973) também publicou micrografias eletrônicas mostrando partículas de argila embebidas em películas gel, mas estas eram partículas em solos desenvolvidos de cinzas vulcânicas e contendo quantidades pequenade gel amorfo (alofana).

Há evidências de recobrimento de óxidos de ferro em minerais de argila finamente divididos em partículas de argila maiores nos solos da Austrália (Fordham \& Norrish, 1979). Inúmeras investigações acerca da questão se os óxidos livres encontrarem-se presentes ou como revestimentos sobre os minerais ou como partículas discretas agregadas (provavelmente ferrihidrita) levaram Sumner (1963), Davitz \& Sumner (1965), Roth et al., (1969) e Ghabru et al., (1990) a concluírem que os óxihidróxidos de ferro estavam presentes como 
recobrimento na caulinita e vermiculita promovendo uma redução na CTC e Hendershot \& Lavkulich, (1983) a obterem em laboratório um decréscimo na CTC ao revestirem amostras de minerais menos reativos (caulinita e quartzo) com $10 \%$ de ferro. Também em condições de laboratório, Greenland \& Mott, (1978); Kavanagh \& Quirk, (1978) e Rengasamy \& Oades, (1977a, b; 1979) fizeram precipitar com óxidos de ferro nos argilominerais, caulinita, ilita e bentonita, e obtiveram um aumento das cargas positivas líquidas na superficie.

Sakurai et al., (1990) mostraram que a quantidade de partículas minerais revestidas artificialmente com sesquióxidos amorfos leva a um acréscimo no valor do PCZ e que ao remover os óxidos de ferro esse acréscimo se manteve (Sakurai et al., 1991).

\subsubsection{Matéria Orgânica}

- A CTC da matéria orgânica do solo é causada pela dissociação de grupos carboxilicos e fenólicos na faixa de $\mathrm{pH}$ entre 5 e 7, e produzem cerca de 5 a $90 \%$ da carga negativa das substâncias húmicas e correspondem a uma acidez de 300 a $1700 \mathrm{cmol}_{\mathrm{c}} \mathrm{kg}^{-1}$ (Raij \& Pech, 1972; Oades, 1984). Já a CTC de diferentes argilominerais é da ordem de 3-5 $\mathrm{cmol}_{\mathrm{c}} \mathrm{kg}^{-1}$ para a caulinita; $30-440 \mathrm{cmol}_{\mathrm{c}} \mathrm{kg}^{-1}$ para ilita; 80-150 $\mathrm{cmol}_{\mathrm{c}} \mathrm{kg}^{-1}$ para vermiculita. Estas comparações explicam porque o húmus, apesar das suas quantidades serem relativamente baixas, tem uma significativa contribuição para a CTC do solo com predominância de caulinita (Stevenson, 1994). Uma considerável parte da fração orgânica encontrase combinada com a fração inorgânica por meio de várias forças de ligação. A interação desses dois componentes pode também modificar a CTC da matéria orgânica e dos argilominerais (Oades, 1989), resultando numa menor quantidade de carga negativa de superficie do complexo organo-mineral em relação à soma das cargas separadas dos dois componentes ( $\mathrm{Yu}, 1997$ ). Como conseqüência, a 
CTC da matéria orgânica e do argilomineral não pode ser considerada aditiva, pois alguns sítios são perdidos por causa dessas associações e, também muitos sítios orgânicos podem ser limitados ao formar complexos com cátions polivalentes (Stevenson, 1994).

Segundo Yu (1997), duas situações podem explicar a causa da não adição da CTC resultante da interação das frações orgânicas e inorgânicas: (1) os colóides orgânicos carregados negativamente podem combinar com os óxidos de ferro e alumínio carregados positivamente ou com sítios positivos das arestas quebradas dos minerais de argila e (2) o húmus é precipitado na superfície dos colóides minerais pela coagulação por cátions polivalentes, exercendo assim um efeito mascarador nos sítios de carga negativa dos colóides minerais.

Para Greenland (1971) no entanto, o comportamento dos ácidos húmicos e fúlvicos na superfície dos argilominerais não levam à formação de recobrimento da superficie. O mecanismo dominante de suas associações com as argilas parece ser a complexação com cálcio, ferro ou mais provavelmente com íons alumínio na superficie da argila.

É raro ocorrer adsorção interlamelar de compostos orgânicos nos argilominerais do tipo $2: 1$, a não ser que os óxihidróxidos atuem como revestidores intermediários. É freqüente observar nos solos, associações de óxihidróxidos de ferro e alumínio com materiais fúlvicos e húmicos por troca de ligantes com a superficie hidroxílica. A força dessas associações sugere que possa haver o envolvimento de vários grupos carboxílicos, dificultando assim, o deslocamento do grupo húmico, mantendo-o inatacado na superficie oxídica (Greenland \& Mott, 1978).

Zhang \& Jiang (1964), observaram mudanças nas cargas positiva e negativa da fração argila de um Rhodic Ferralsol, contendo grande quantidade de óxido de ferro livre e após sofrer remoção da matéria orgânica, a quantidade de carga líquida negativa diminuiu a um $\mathrm{pH}$ maior que o PCLZ, o que é explicado 
principalmente pelo aumento das cargas positivas em relação ao decréscimo da carga negativa. Evidenciando assim, o processo da não adição da CTC mencionado por Yu (1997) como também fica demonstrado o importante papel dos óxidos de ferro na formação dos complexos organo-minerais nos solos.

Investigações como as de Parfitt et al., (1995) mostram uma significativa contribuição do carbono orgânico e dos sítios dos argilominerais para a CTC de horizontes superficiais e subsuperficiais de solos da Nova Zelândia. Fernández Marcos et al., (1998) ao medirem a CTC/CTA em experimentos de percolação com amostras contendo carga variável e tamponadas préviamente com acetato de amônio e com matéria orgânica removida, observaram que um leve efeito tampão permaneceu, e isto se deveu à liberação de sesquióxidos dos complexos orgânicos e das superficies dos argilominerais que se encontravam préviamente ligados com o ânion acetato. Foi também observado pelos autores, que a remoção da matéria orgânica causou decréscimo drástico na $\mathrm{CTC}$, bem como na dependência do $\mathrm{pH}$, refletindo uma maior contribuição da matéria orgânica na CTC.

A matéria orgânica pode afetar também o PCZ do solo. O PCZ do horizonte A é geralmente menor que o PCZ do horizonte B (Gallez et al., 1976; Hendershot et al., 1979; Laverdière \& Weave, 1977; Raij \& Peech, 1972) e aumenta acentuadamente após a remoção da matéria orgânica (Hendershot \& Lavkulich, 1979).

Peixoto (1995) ao estudar a dinâmica de carga elétrica superficial em três latossolos roxos do Paraná, sob floresta nativa, em função da matéria orgânica e mineralogia onde foram amostrados solos caulinítico, sesquioxidico e gibbsítico, observou que em geral a matéria orgânica do solo contribuiu para um aumento da CTC e para uma diminuição dos valores do PCPLZ de todas as amostras estudadas, mas ambos foram influenciados pelo alumínio complexado pela matéria orgânica do solo e pela presença da gibbsita. A CTC devido à matéria orgânica do solo foi mais influenciada pelo $\mathrm{pH}$ do que a CTC dos minerais do 
solo ao se comparar o maior aumento no excesso de carga superficial iônica específica relativa líquida $\left(\Delta \mathbf{q}=\mathbf{q}_{\mathbf{L i}}{ }^{+}-\mathbf{q}_{\mathbf{C}}{ }^{-}\right)$por unidade de aumento do $\mathrm{pH}$ do solo aos $2,5 \mathrm{~cm}$ em relação aos $250 \mathrm{~cm}$ de profundidade, independente da mineralogia do solo. Foi também observado pelo autor, a importância da matéria orgânica do solo na geração de carga elétrica negativa que foi mais pronunciada no solo gibbsítico em relação ao caulinítico. Mesmo com maior teor de matéria orgânica, o solo gibbsítico manteve menores valores de carga negativa que os demais solos na faixa de $\mathrm{pH}$ estudada, indicando o forte efeito das cargas positivas predominantes da gibbsita observados aos $250 \mathrm{~cm}$. Portanto, a retenção de cátions em solos gibbsíticos depende largamente da presença da matéria orgânica.

Siqueira et al.,(1990) estudando latossolos e podzólicos brasileiros, observaram que a contribuição da matéria orgânica do solo na variação do $\mathrm{PCZ}$, isto é PESN, dependem do grau de intemperismo do solo, avaliado pelo índice ki $\left(\mathrm{SiO}_{2} / \mathrm{Al}_{2} \mathrm{O}_{3}\right)$. Eles concluíram que a diminuição do PESN por aumento de unidade de carbono foi menor em solos com valores ki entre 0,06 e 0,6. A mesma tendência foi observada por Peixoto (1995) ao comparar a diminuição do PCLZ entre as profundidades do solo graças à presença da matéria orgânica observando a seguinte seqüência: solo sesquioxídico $>$ gibbsítico $>$ caulinítico. 


\section{MATERIAL E MÉTODOS}

\subsection{Solos Utilizados}

As amostras de solos foram coletadas nos municípios de Ribeirão Preto, Miguelópolis e Guaíra, a duas profundidades, superficial $\left(\begin{array}{llll}0 & \text { a } 20 \mathrm{~cm}\end{array}\right)$ e subsuperficial na maior expressão do horizonte $\mathrm{B}$, de acordo com levantamentos pedológicos realizados por Oliveira \& Menk (1984), Oliveira \& Prado (1987, 1992). A classificação dos solos amostrados e o número dos perfis, próximo dos quais as amostras foram coletadas, encontram-se na Tabela 2. A inclusão de uma Terra Roxa Estruturada foi feita propositalmente como um marco de solo com material de origem semelhante, mas num estádio de evolução menos adiantado.

Tabela 2- Classificação dos solos utilizados e número dos perfis, próximo dos quais as amostras foram coletadas.

\begin{tabular}{|c|c|c|c|}
\hline Solo & Classificação & Perfil & Local \\
\hline $\mathrm{TE}$ & Terra Roxa Estruturada & 1103 & $\begin{array}{l}\text { Ribeirão } \\
\text { Preto }\end{array}$ \\
\hline LR ác-Rib & Latossolo Roxo ácrico & 1348 & $\begin{array}{l}\text { Ribeirão } \\
\text { Preto }\end{array}$ \\
\hline LR ác-Gua & Latossolo Roxo ácrico & 1453 & Guaira \\
\hline LUna ác-argare & Latossolo variação Una ácrico textura areno-argilosa & 1457 & Guaira \\
\hline LUna ác- mtarg & Latossolo variação Una ácrico textura muito argilosa & 1460 & $\begin{array}{l}\text { Miguelópo } \\
\text { lis }\end{array}$ \\
\hline
\end{tabular}

os números dos perfis pertencem à soloteca do Instituto Agronômico de Campinas (IAC). 


\subsection{Análises químicas, físicas e mineralógicas}

A caracterização química e física das amostras já foi apresentada por Alleoni (1992) e, basicamente, a metodologia seguida para tal finalidade foi a descrita por Camargo et al., (1986), que se resume da seguinte maneira:

\subsubsection{Análises químicas}

a) $\mathrm{pH}$ em $\mathrm{H}_{2} \mathrm{O}$ e em $\mathrm{KCl} 1 \mathrm{M}$ relação solo-solução 1:2,5.

b) $\Delta \mathrm{pH}=\mathrm{pH} \mathrm{KCl}-\mathrm{pH} \mathrm{H} \mathrm{H}_{2} \mathrm{O}$

c) Ponto de efeito salino nulo (PESN): as amostras foram tituladas com $\mathrm{H}^{+}$e $\mathrm{OH}$ a três diferentes concentrações de $\mathrm{KCl}$, sendo o $\mathrm{PESN}$ o valor de $\mathrm{pH}$ no ponto de interseção das curvas de titulação.

d) $\Delta \mathrm{pH}_{\mathrm{PESN}}=\mathrm{pH}_{\mathrm{KCl}}-\mathrm{pH}_{\mathrm{PESN}}$

e) Carbono orgânico $\left(\mathrm{g} \mathrm{kg}^{-1}\right)$ : oxidação da matéria orgânica do solo com solução de dicromato de potássio em presença de ácido sulfúrico e determinação por titulometria do excesso de dicromato com sulfato ferroso amoniacal.

f) Ferro e alumínio cristalinos: em meio tamponado com bicarbonato de sódio $\mathrm{pH}$ 7,3 , ferro e alumínio foram reduzidos pelo ditionito de sódio e complexados pelo citrato de sódio, permanecendo em solução.

g) Ferro e alumínio não cristalinos: obtidos por solubilização do ferro/alumínio não cristalinos em ácido oxálico e seu sal de amônio.

h) Teores totais de óxidos $\left(\mathrm{SiO}_{2}\right.$ e $\left.\mathrm{Fe}_{2} \mathrm{O}_{3}\right)$ obtidos pelo ataque com ácido sulfúrico.

i) Índice de intemperização $\mathrm{ki}=\left(\mathrm{SiO}_{2} / \mathrm{Al}_{2} \mathrm{O}_{3}\right) \times 1,7$. 


\subsubsection{Análises físicas}

a) Análise granulométrica: método da pipeta.

b) Superficie específica (SE); empregou-se o método utilizado por Cihacek \& Bremmer (1979), baseado na técnica de retenção de éter monoetílico do etilenoglicol (EMEG), proposto por Heilman et al.,(1965).

\subsubsection{Análise mineralógica qualitativa.}

3.2.3.1 Da fração argila total

3.2.3.1.1 Obtenção das frações do solo.

Foram pesados aproximadamente $50 \mathrm{~g}$ de amostra de solo $(<2,0 \mathrm{~mm})$ que foi , em seguida, fracionada em areia, silte e argila. A quantidade de solo citada foi transferida para frasco de polietileno com capacidade para $500 \mathrm{~mL}$, e então adicionaram-se $250 \mathrm{~mL}$ de água destilada, e a suspensão foi agitada durante 12 horas em agitador horizontal. Após agitação, a suspensão foi passada através de uma peneira de 0,053 $\mathrm{mm}$ para separar a areia total, das frações silte e argila.

Em seqüência, procedeu-se à separação do silte da argila, para isso a fração argila foi então, separada por sifonamento numa profundidade de $10 \mathrm{~cm}$ obedecendo a lei de Stokes. Esta operação foi repetida de sete a doze vezes dependendo do conteúdo da argila na amostra. A fração argila sifonada foi coletada em cápsula de porcelana previamente pesada, e em seguida levada a secar em estufa por convecção de ar forçado numa temperatura de $40^{\circ} \mathrm{C}$ até peso constante. A fração silte foi obtida do processo de centrifugação a $2000 \mathrm{mpm}$ durante $15 \mathrm{~min}$. 
3.2.3.1.2 Extração do ferro livre: já descrito no item 3.2.1

3.2.3.1.3 Extração do ferro amorfo: já descrito no item 3.2.1

3.2.3.1.4 Análise de Difração de Raios X da fração argila total.

A fração argila total deferrificada com ditionito-citrato-bicarbonato de sódio (DCB) foi analisada por difratometria de raios $\mathrm{X}(\mathrm{DRX})$ seguindo a saturação padrão de cátions $\left(\mathrm{K}^{+} \mathrm{e} \mathrm{Mg}^{2+}\right)$ e tratamento térmico $\left(350^{\circ}\right.$ e $\left.550^{\circ} \mathrm{C}\right)$. Amostras de $250 \mathrm{mg}$ em duplicatas foram pesadas e transferidas para tubos de centrifuga de polipropileno. Uma das subamostras foi saturada com $\mathrm{Mg}^{2+}$ por múltiplas lavagens com $\mathrm{MgCl}_{2}, 0,5 \mathrm{M}$ e a outra foi saturada com $\mathrm{K}$ pela lavagem com $\mathrm{KCl} 1 \mathrm{M}$. Em ambos os tratamento, o excesso de sal foi removido por repetidas lavagens com água deionizada seguida de centrifugação a 2000 rpm por $5 \mathrm{~min}$. As argilas resultantes foram dispersas em água usando um agitador vortexer. Foram preparadas lâminas orientadas de argilas saturadas com $\mathrm{Mg}$ e K a $25^{\circ} \mathrm{C}$, e então, submetidas à difração de raios X (difratômetro Philips PW 1830 com radiação de $\mathrm{CuK} \alpha(50 \mathrm{~mA}, 40 \mathrm{KV})$ de 3 a $30^{\circ} 2 \theta$ usando um step num intervalo de $1^{\circ} 2 \theta$ e um tempo de passo de $5 \mathrm{~s}$ ou de $2 \mathrm{~s}$ ). As argilas saturadas com $\mathrm{K}$ foram então aquecidas por $3 \mathrm{~h}$ a $350^{\circ} \mathrm{C}\left(\mathrm{K}-350^{\circ} \mathrm{C}\right)$, e submetidas à difração de raios $\mathrm{X}$ sendo em seguida aquecidos a $550^{\circ} \mathrm{C}\left(\mathrm{K}-550^{\circ} \mathrm{C}\right)$ no mesmo tempo e submetidas à difração de raios $\mathrm{X}$. Os minerais de argila expansíveis foram identificados após passagem das amostras de argila saturadas com $\mathrm{Mg}$ e expostos a uma amosfera saturada com etileno glicol (EG-Mg) por $24 \mathrm{~h}$. A identificação qualitativa de vários argilominerais foi baseada na posição apropriada dos picos de difração seguida de cada tratamento. 
3.2.3.2 Do óxido de ferro.

A caracterização mineralógica dos óxidos de ferro foi iniciada pelo processo de dissolução seletiva da caulinita, haloisita e gibbsita usando $\mathrm{NaOH} 5 \mathrm{M}$ à quente segundo Norrish \& Taylor (1961) modificado por Kämpf \& Schwertmann (1982).

\subsection{Procedimento do $\mathrm{NaOH} 5 \mathrm{M}$ à quente.}

Foi pesado $1 \mathrm{~g}$ da fração argila e transferido para um copo de teflon onde se adicionaram-se, aos poucos, $100 \mathrm{~mL}$ de $\mathrm{NaOH} 5 \mathrm{M}$ à quente. A suspensão tampada com um vidro de relógio foi levada a ferver num banho de areia por $1 \mathrm{~h}$ numa temperatura constante de $105^{\circ} \mathrm{C}$. A amostra foi retirada do banho de areia, esfriada com água corrente, centrifugada a $2000 \mathrm{rpm}$ por $5 \mathrm{~min}$, sendo a solução sobrenadante, descartada. Os resíduos foram então seqüencialmente lavados com $\mathrm{NaOH} 5 \mathrm{M}$ a frio, $\mathrm{HCl}$ 0,5 $\mathrm{M}$ (para dissolver a sodalita) e $\left(\mathrm{NH}_{4}\right)_{2} \mathrm{CO}_{3}$ para remover o excesso de sódio e duas vezes com água destilada. Os resíduos lavados foram colocados em cápsulas de porcelana e secos a $110^{\circ} \mathrm{C}$ num tempo de $12 \mathrm{~h}$, para remover o excesso de $\mathrm{NH}_{4}$ e $\mathrm{CO}_{3}$. Os resíduos secos foram removidos, moídos em gral de ágata e armazenados para análise. 
3.2.3.2.2 Análise de difração de raios $\mathrm{X}$ da fração óxidos de ferro.

A fração óxidos de ferro concentrados foi analisada por DRX, sendo a lâmina montada em pó (não orientada). Cerca de $100 \mathrm{mg}$ dos resíduos foram dopados com $5 \%$ de sílica, um padrão interno, e misturados em gral de ágata. A mistura foi colocada num suporte de sílica e levemente compactada com uma lamínula de vidro para evitar orientação preferencial dos grãos dos minerais. Os padrões de varredura $\left(0,02^{\circ} 2 \theta\right.$ por $\left.5 \mathrm{~s}\right)$ foi obtido de $3-30^{\circ} 2 \theta$.

\subsubsection{Análises mineralógicas quantitativa}

A determinação quantitativa da caulinita e gibbsita foi feita pela Análise Térmica Diferencial (ATD) na fração argila deferreficada e isenta de matéria orgânica e saturada com $\mathrm{Mg}$ usando um instrumento Rigaku stander. O princípio básico desta análise foi o de desidratar e de desoxidrolizar numa faixa de temperatura de interesse relacionada à gibbsita e a caulinita (Resende, 1976; Curi, 1983; Palmieri, 1986).

Uma quantidade apropriada de material de argila $( \pm 100 \mathrm{mg})$ foi transferida para um gral de ágata onde se adicionou o mesmo peso do padrão $\left(\mathrm{Al}_{2} \mathrm{O}_{3}\right.$ calcinado $)$ e misturando-a em seguida. Toda essa mistura é transferida para um suporte de ATD e no outro suporte o padrão é transferido sem a amostra da argila. A amostra foi então aquecida a $350^{\circ}$ e a $550^{\circ} \mathrm{C}$. Registraram-se o peso inicial da amostra, a perda de peso com o aumento de temperatura, a derivada da perda de peso pela a mudança na temperatura da amostra relacionada ao material de referência durante o aquecimento (ATD). A quantidade de gibbsita foi determinada usando a porcentagem de perda de peso da amostra numa faixa de $250-300^{\circ} \mathrm{C}$ para posteriormente calcular a perda de peso correspondente. Um 
procedimento semelhante foi usado para determinar o conteúdo de caulinita baseado na perda de peso dentro da faixa de $400-600^{\circ} \mathrm{C}$.

\subsection{Parte experimental}

\subsubsection{Carga permanente efetiva $\left(\sigma_{0}\right)$}

O método utilizado para a determinação da carga permanente efetiva envolveu somente medidas de adsorção de cátions metálicos na cavidade ditrigonal de filossilicatos 2:1. Foram medidas, as diferenças de seletividade utilizando-se soluções de cloreto de césio e lítio entre uma superfície de siloxana e grupos de superficies ionizáveis.

Para tanto, todas as soluções foram preparadas usando água com alto grau de pureza, obtida por meio de sua passagem através de um purificador dotado de colunas de resina trocadora e de retenção de carbono, com base na escala molalidade ( ), definida como mol de soluto por quilo de solução ( $\mathrm{mol} \mathrm{kg}^{-1}$ ) (Clegg \& Whitifield 1991). A utilização da molalidade permite o cálculo direto do número de moles de um soluto numa pasta de solo ou suspensão quando a massa da pasta ou da suspensão é conhecida.

3.3.1.1 Preparo dos adsorventes saturados com cloreto de césio $(\mathrm{CsCl})$.

Esta fase do método envolveu a saturação dos sítios de superficie do solo com os íons césio $\left(\mathrm{Cs}^{+}\right)$e cloreto $\left(\mathrm{Cl}^{-}\right)$, por meio do equilíbrio com soluções de cloreto de césio em diferentes forças iônicas, para posterior ensaio de adsorção com o referido cátion. 
Os adsorventes saturados com césio foram obtidos colocando-se a fração do solo seco ao ar (<2,0 mm) com solução de cloreto de césio $(\mathrm{CsCl})$. Para isso, foram pesados 3,5 g de amostra de solo seca ao ar em tubos de centrifuga de policarbonato de $50 \mathrm{~mL}$, previamente lavados em solução ácida de $\mathrm{HCl}$ 1:1 e equilibrada uma vez com $24 \mathrm{~g}$ da solução de $\mathrm{CsCl} 0,5 \mathrm{~mol} \mathrm{~kg}^{-1}$ agitando-se por 30 min em um agitador horizontal a 115 ciclos por min. Após agitação, os tubos com as amostras foram deixados em repouso por $15 \mathrm{~min}$, a fim de remover, com auxílio de um bastão de vidro, a fração de matéria orgânica leve. Em seguida, as amostras foram centrifugadas por 35 min numa centrifuga Sorvall RC5C PLUS a 9.820 de força centrifuga relativa (FCR) sendo a solução sobrenadante descartada.

Para reduzir a concentração do excesso de íons, as amostras foram então equilibradas por três lavagens com cloreto de césio, ou seja duas lavagens foram feitas adicionando-se $20 \mathrm{~g}$ da solução de $\mathrm{CsCl} 0,1 \mathrm{~mol} \mathrm{~kg}^{-1}$ agitando-se por 30 minutos, centrifugando e descartando o sobrenadante e uma terceira lavagem adicionando-se $20 \mathrm{~g}$ da solução de $\mathrm{CsCl} 0,05 \mathrm{~mol} \mathrm{~kg}^{-1}$, agitando-se por $30 \mathrm{~min}$, para reduzir a concentração dos íons entranhados, centrifugando-se e descartando-se a solução sobrenadante. Essas lavagens foram realizadas na mesma FCR da saturação dos solos com os íons $\mathrm{Cs}^{+}$e $\mathrm{Cl}^{-}$.

Após a terceira e última lavada, as pastas de solos remanescentes nos tubos da centrífuga foram ransferidas para placas de Petri, previamente lavadas em solução ácida e esterilizadas, com auxílio de uma espátula e misturadas para produzir uma pasta de solo uniforme.

As pastas de solo remanescentes, da placa de Petri, foram armazenadas num dessecador com água deionizada a $4^{\circ} \mathrm{C}$ até uso, cerca de 48 horas após o seu preparo. Este tempo mininiza a dissolução mineral, a competição subseqüente de Al sobre sítios de troca de cátion, e a migração de $\mathrm{Cs}^{+}$nas entrecamadas de filossilicatos (Anderson 1989; Chorover, 1993). 
Da pasta obtida foi pesado $0,5 \mathrm{~g}$, fazendo-se três repetições, transferindose para cadinho de porcelana, previamente lavado em solução ácida e secos por $48 \mathrm{~h}$ a $110^{\circ} \mathrm{C}$, para determinação do conteúdo de água na pasta de solo usando a expressão (13).

$$
H_{2} \mathrm{O}, \text { amostra }=\frac{M_{\mathrm{H}_{2} \mathrm{O}}}{\left(M_{C D}+P U\right)-\left(M_{C D}\right)}
$$

$\mathrm{PU}=$ massa da pasta úmida

$\mathrm{M}_{\mathrm{CD}}=$ massa do cadinho vazio

$\mathrm{M}_{\mathrm{H} 2 \mathrm{O}}=$ massa de água na amostra $(\mathrm{g})$

$\mathrm{PS}=$ massa da pasta seca

$$
M_{H_{2} O}=\left(M_{C D}+P U-M_{C D}\right)-\left(M_{C D}+P S-M_{C D}\right)
$$

A massa seca atual do adsorvente $\left(\mathrm{M}_{\mathbf{S}}\right)$ usada no experimento foi calculada por:

$$
\mathrm{C}_{\mathrm{SS}}=1-\mathrm{M}_{\mathrm{H} 2 \mathrm{O}}
$$

$\mathrm{C}_{\mathrm{Ss}}$ é o conteúdo de solo na pasta

$$
M_{S}=\left(M_{T C}+P_{S}-M_{T}\right) \cdot C_{S S}
$$

em que, $\mathrm{M}_{\mathrm{S}}$ é a massa atual do adsorvente; $\mathrm{M}_{\mathrm{TC}}+$ Psé a massa do tubo da centrífuga com a pasta do solo, $\mathrm{M}_{\mathrm{T}}$ é a massa do tubo da centrífuga vazio. 


\subsubsection{Quantificação da carga permanente efetiva $\left(\sigma_{0}\right)$}

O procedimento consistiu de quatro passos, envolvendo equilíbrio e centrifugação:

Passo 1 : Equilibrio das amostras de solos saturados com soluções de $\mathrm{CsCl}$

Foram transferidas para tubos de centrífuga (previamente lavados em solução ácida) de $50 \mathrm{~mL}\left(\mathrm{M}_{\mathrm{T}}\right)$ triplicatas de $0,35 \mathrm{~g}$ das amostras de pasta seca de solo saturadas com $\mathrm{CsCl}$ e suspensas em $35 \mathrm{~g}$ de solução de $\mathrm{CsCl} 0,05 \mathrm{~mol} \mathrm{~kg}^{-1}$ a $\mathrm{pH} 6,0 \pm 0,1$. O ajuste de $\mathrm{pH}$ foi feito utilizando-se soluções de $\mathrm{CsOH}$ ou de $\mathrm{HCl}$ nas concentrações de $0,05 \mathrm{~mol} \mathrm{~kg}^{-1}$. As suspensões passaram por um banho ultrasônico por $10 \mathrm{~min}$ seguidas de agitação de $10 \mathrm{~s}$ num vortexer (velocidade máxima) e equilíbrio de $60 \mathrm{~min}$ num agitador horizontal com 110 ciclos por min, na temperatura de $25 \pm 1^{\circ} \mathrm{C}$. Após o tempo de equilíbrio, as amostras foram centrifugadas a $8.820 \mathrm{FCR}$ por 30 minutos e as soluções sobrenadantes foram descartadas.

Passo 2: Redução da concentração de césio entranhado e formação dos complexos de esfera interna netre o ín césio e as superficies siloxanas

As amostras de solos foram lavadas com uma alíquota de $30 \mathrm{~g}$ de etanol $(\mathrm{EtOH})$ a $95 \%$, sonificadas por $5 \mathrm{~min}$, agitados por três vezes num vortexer a velocidade máxima durante $10 \mathrm{~s}$, seguida de outra sonificação por $5 \mathrm{~min}$. As suspensões etanólicas foram centrifugadas a $8820 \mathrm{RCF}$ por $30 \mathrm{~min}$ e as soluções sobrenadantes foram descartadas. Esta lavagem foi repetida (duas lavagens foram 
suficientes) até que nenhum cloreto tivesse sido detectado na solução sobrenadante, testada com uma gota da solução de $\mathrm{AgNO}_{3} 1 \mathrm{~mol} \mathrm{~kg}^{-1}$.

Os tubos de centrifuga contendo solos remanescentes foram destampados e levados a secar a $65^{\circ} \mathrm{C}$ por 48 hs numa estufa para a formação de complexos de $\mathrm{Cs}^{+}$de superficie de esfera interna com os sítios siloxanos (Chorover, 1993).

Passo 3: Deslocamento dos íons césio dos grupos funcionais ionizáveis

As amostras de solo seca foram ressuspensas em $30 \mathrm{~g}$ da solução de $\mathrm{LiCl}$ $0,01 \mathrm{~mol} \mathrm{~kg}^{-1}$ a pH 6,0. O ajuste foi feito utilizando-se solução de $\mathrm{LiOH}$ ou $\mathrm{HCl}$, na concentração de $0,01 \mathrm{~mol} \mathrm{~kg}^{-1}$ seguida pela mesma seqüência de banho ultrasônico do passo 2. As suspensões foram agitadas por $30 \mathrm{~min}$ utilizando-se um agitador horizontal de 110 ciclos por minuto e em seqüência centrifugadas a $8.820 \mathrm{RCF}$ por $60 \mathrm{~min}$, a fim de deslocar o $\mathrm{Cs}^{+}$dos sítios de menor seletividade $\left(\mathrm{Li}^{+} \rightarrow \mathrm{Cs}^{+}\right)$. As soluções sobrenadantes foram transferidas para recipientes plásticos de $60 \mathrm{~mL}$, previamente lavados em solução ácida e pré pesados $\left(\mathrm{M}_{\mathrm{RP}}\right)$, e as massas dos recipientes mais soluções foram registradas $\left(M_{R P}+\right.$ soBREN $)$. Os tubos da centrifuga contendo os solos remanescentes e soluções entranhadas foram pesados $\left(\mathrm{M}_{\mathrm{T}+\mathrm{SR}+\text { SOBREN }}\right)$ para quantificar a massa de solução entranhada $\left(\mathrm{M}_{\mathrm{ELi}}\right)$. As soluções foram acidificadas a $\mathrm{pH}$ 2,0 adicionando-se ácido nítrico concentrado e estocados a $4^{\circ} \mathrm{C}$ para análise.

Passo 4: Extração do íon césio com $\mathrm{AcONH}_{4}$ dos sítios com carga estrutural.

Para extrair o $\mathrm{Cs}^{+}$dos grupos funcionais que exibem alta seletividade $\left(\mathrm{Li}^{+}\right.$ $\rightarrow \mathrm{Cs}^{+}$), aos solos remanescentes nos tubos foram adicionados $30 \mathrm{~g}$ da solução de 
acetato de amônio $\left(\mathrm{AcONH}_{4}\right)$ 1,0 mol kg${ }^{-1}$, seguida pela mesma seqüência de banho ultrasônico dos passos 2 e 3 . Agitaram-se as suspensões por $30 \mathrm{~min}$ em agitador horizontal com 110 ciclos por min e, então, centrifugaram-se a $3.444 \mathrm{RCF}$ por 15 minutos. As soluções sobrenadantes extraídas com $\mathrm{AcONH}_{4}$ foram transferidas para frascos plásticos de $250 \mathrm{~mL}$, previamente lavados em solução ácida de $\mathrm{HCl} 1: 1 \mathrm{e}$ pré pesados $\left(\mathrm{M}_{\mathrm{FRVAZOO}}\right)$. Repetiram-se as exrações por três vezes assumindo que nenhuma quantidade significante de $\mathrm{Cs}^{+}$estivesse presente na solução sobrenadante, baseado nos estudos preliminares obtidos por Anderson \& Sposito (1991). Combinaram-se todas as soluções extraídas com $\mathrm{AcONH}_{4}$, formando uma única solução a qual foi pesada ( $\left.\mathrm{M}_{\mathrm{NH} 4 \text { EXT }}\right)$, e armazenada para análise (acidificou-se a solução a $\mathrm{pH} 2,0$ com ácido nítrico concentrado e estocada a $\left.4^{\circ} \mathrm{C}\right)$. O AcONH4 tem sido considerado um bom extrator de $\mathrm{Cs}^{+}$ porque ele é um ácido fraco de Lewis com baixa energia de hidratação e porque ele contribui para uma melhor emissão atômica na análise de $\mathrm{Cs}^{+}$(Anderson \& Sposito, 1991).

3.3.1.3 Análises químicas de $\mathrm{Cs}^{+}$

As determinações de $\mathrm{Cs}^{+}$nos extratos de $\mathrm{LiCl}$ e de $\mathrm{AcONH}_{4}$ foram feitas por espectrofometria de emissão atômica (Espectrofotômetro de Absorção Atômica Varian modelo AA12/1475). A calibração dos padrões foram preparadas com base na massa da solução estoque de CsCL 0,05 mol. kg ${ }^{-1}(8,418 \mathrm{~g} \mathrm{CsCl} \mathrm{99 \%}$ metal por kg de solução) nas mesmas matrizes de $\mathrm{LiCl}$ e $\mathrm{AcONH} 4$ como as amostras. Todas as diluições foram feitas também com soluções matrizes de $\mathrm{LiCl}$ e $\mathrm{AcONH}_{4}$. Todas as amostras, padrões e diluições continham potássio com o $\mathrm{KCl}$ ( $5 \mathrm{~g}$ de $\mathrm{K} \mathrm{kg}^{-1}$ ), adicionado para prevenir a ionização do $\mathrm{Cs}^{+}$na chama. As leituras do $\mathrm{Cs}^{+}$na chama foram feitas no comprimento de onda de $852,1 \mathrm{~nm}, 1,0$ 
$\mathrm{nm}$ de largura de fenda, em chama de ar-acetileno, com tempo de leitura de $1 \mathrm{~s}$ para três leituras, usando a calibração na faixa linear.

3.3.1.4 Determinação da carga permanente efetiva $\left(\sigma_{0}\right)$ e da $\sigma_{H}$

A carga de superficie variável, $\sigma_{\mathrm{H}}\left(\mathrm{mol}_{\mathrm{C}} \mathrm{kg}^{-1}\right.$ solo $)$ pode ser medida pela quantidade de $\mathrm{Cs}^{+}$trocável liberada da superficie seguindo o equilíbrio do solo com $\mathrm{LiCl}$ (item 3.3.1.2 passo 3):

$$
\sigma_{H}=\kappa_{C s(\text { Li sobren })} \cdot \frac{M_{L i, \text { adicionada }}}{M_{S}}
$$

onde, $K_{\mathrm{Cs} \text { (Li Sobr) }}$ é a molalidade de $\mathrm{Cs}^{+}$na solução sobrenadante, $\mathrm{M}_{\mathrm{Li} \text { adic. é a massa }}$ da solução de $\mathrm{LiCl}$ adicionada (massa da solução sobrenadante mais solução entranhada após centrifugação), e MS é a massa seca atual do adsorvente (eq. 16) usado.

A carga de superficie permanente efetiva, $\sigma_{\mathrm{O}}\left(\mathrm{mol}_{\mathrm{C}} \mathrm{kg}^{-1}\right.$ solo) é calculada como excesso de $\mathrm{Cs}^{+}$retido na carga de superficie específica relativa, seguindo a troca $\mathrm{Li}^{+} \rightarrow \mathrm{Cs}^{+}$(Anderson \& Sposito, 1991):

$-\sigma_{0}=n_{C S T O t}\left(N_{4} E X T\right)-M_{E(L i)} * \kappa_{C S}($ Li Srobr $)$ 
onde: $n_{C s}$ Tot(NH4 EXT) é o número total de mols de $\mathrm{Cs}^{+}$do solo extraído pelo $\mathrm{AcONH}_{4}$ por unidade de massa do adsorvente seco; $\mathrm{M}_{\mathrm{E}(\mathrm{L})}$ é a massa da solução de $\mathrm{LiCl}$ entranhada por unidade de massa do adsorvente seco.

O termo $n_{C s} \operatorname{Tot}(N H 4$ EXT) da equação 18 foi calculado da seguinte forma:

$$
{ }_{\text {CsTot }}^{n}\left(\mathrm{NH}_{4}{ }_{\mathrm{EXT}}\right)=\kappa_{\mathrm{Cs}, \mathrm{EXT}}\left(\frac{M_{N H}{ }_{\mathrm{EXT}}}{M_{S}}\right)
$$

onde: $k_{C s, E X T}$ é a molalidade do Cs na solução extratora $\mathrm{AcONH}_{4} ; M_{N H 4}$ EXT é a massa da solução extratora de $\mathrm{AcO} \mathrm{NH}_{4}$.

O termo $M_{E(L) ~}$ da equação 18 foi determinado como:

$$
M_{E(L i)}=M_{T+S O L O+S O B R E N}-M_{T}-M_{S}
$$

onde:

A densidade da carga total de superície, $\sigma_{\text {TOTAL }}\left(\mathrm{mol}_{\mathrm{C}} \cdot \mathrm{kg}^{-1}\right.$ solo), medida pela adsorção do $\mathrm{Cs}^{+}$pode ser calculada como a soma de $\sigma_{\mathrm{O}}$ e $\sigma_{\mathrm{H}}$

3.3.2 Determinação do coeficiente de seletividade

Para descrever quantitativamente a seletividade cationica na reaçãode troca $\mathrm{Li}^{+} \rightarrow \mathrm{Cs}^{+}$utiliza-se do coeficiente de seletividade, conforme descrito a seguir. Considera-se que a constante do equilíbrio termodinâmico para reações de roca 
binária monovalente-monovalente entre uma superficie sólida e solução aquosa

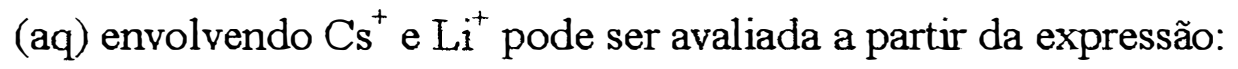

$$
\mathrm{LiX}+\mathrm{Cs}^{+}(\mathrm{aq}) \rightarrow \mathrm{Cs} \mathrm{X}+\mathrm{Li}^{+}(\mathrm{aq})
$$

onde: $\mathrm{LiX}$ e CsX, representam os cátions $\mathrm{Li}^{+}$e $\mathrm{Cs}^{+}$na fase trocadora; $\mathrm{Li}^{+}$(aq) e $\mathrm{Cs}^{+}$(aq) representam os cátions Li e Cs na solução .

Da equação (21) a constante de equilibrio termodinâmico $\left(\mathrm{K}_{\mathrm{T}}\right)$ pode ser expressa como:

$$
K_{T}=\frac{a_{C S X} \cdot a_{L i}(a q)}{a_{L i X} \cdot a_{C S}(a q)}
$$

onde: $a_{\mathrm{CsX}}$ e $a_{\mathrm{LXX}}=$ atividades, respectivamente, dos cátions Cs e Li na fase rocadora; $a_{\mathrm{Li} \mathrm{(aq)}}$ e $a_{\mathrm{Cs}(\mathrm{aq})}=$ atividades, respectivamente, dos cátions Cs e Li na solução.

Para a resolução dessa equação é bem mais fácil determinar as atividades dos cátions em solução do que os cátions adsorvidos na superfície do colóide. Assim, a grande limitação do seu uso em solos é a determinação da atividade dos cátions adsorvidos. Vanselow (1932), sugeriu a fração molar $\left(\boldsymbol{x}_{\boldsymbol{i}}\right)$ para expressar a atividade do cátion adsorvido, considerando a fase trocadora como solução sólida ideal. 
Fração molar da fase sólida

$$
\bar{x}_{L i}=\frac{(\operatorname{LiX})}{(\operatorname{Cs} X+\operatorname{Li} X)} ; \bar{x}_{C s}=\frac{(\operatorname{Cs} X)}{(\operatorname{Cs} X+\operatorname{Li} X)}
$$

Fração molar da fase solução:

$$
x_{L i}=\frac{(L i a q)}{(C s a q+L i a q)} \quad ; \quad x_{C s}=\frac{(C s a q)}{(C s a q+L i a q)}
$$

Desta forma, o coeficiente de seletividade condicional é obtido conforme a equação:

$$
c_{{ }_{B X}}=\frac{\overline{x_{0}} \cdot a_{4}}{\bar{x}_{i} \cdot a_{0}}
$$

onde: ${ }^{\mathrm{C}} \mathrm{Kex}=$ coeficiente de seletividade de Vanselow

$x_{L i}$ e $x_{C s}$ frações molares, respectivamente, dos cátions Li e Cs adsorvidos na fase trocadora;

$a_{L i}$ e $a_{C s}$ atividades, respectivamente, dos cátions Li e Cs na solução; $\mathrm{X}$ representa $1 \mathrm{~mol}$ da carga trocadora

As atividades dos íons na fase sólida são calculadas por meio das equações:

$$
\begin{aligned}
& a_{C s X}=f_{C S} \cdot x_{C s} \\
& a_{L i X}=f_{L i} \cdot x_{L i}
\end{aligned}
$$


Substituindo as equações 26 e 27 na eq.(21) obtêm-se:

$$
\begin{gathered}
K_{T}-\frac{f_{C s} \cdot x_{C s} \cdot a_{L i}(a q)}{f_{L i} \cdot x_{L i} \cdot a_{C s}(a q)} \\
C_{E X}=\frac{\bar{x} C s \cdot a_{L i}(a q)}{\bar{x} L i \cdot a_{C s}(a q)}
\end{gathered}
$$

O coeficiente de seletividade para a troca $\mathrm{Li}^{+} \rightarrow \mathrm{Cs}^{+}$pode ser calculado por:

Considerando que:

$$
\begin{aligned}
& a_{C s(\mathrm{aq})}=\kappa_{\mathrm{Cs}} * \gamma_{\mathrm{Cs}} \\
& a_{\mathrm{Li}(\mathrm{aq})}=\kappa_{\mathrm{Li}} * \gamma_{\mathrm{Li}}
\end{aligned}
$$

onde:

$\kappa_{\mathrm{Cs}}$ e $\kappa_{\mathrm{Li}}=$ molalidade, respectivamente, dos cátions Cs e Li na solução aquosa em equilibrio;

$\gamma_{\mathrm{Cs}}$ e $\gamma_{\mathrm{Li}}=$ coeficientes de atividade, respectivamente, dos cátions $\mathrm{Cs}^{+}{\mathrm{e} \mathrm{Li}^{+} \mathrm{em}}^{\mathrm{e}}$ solução; 
Substituindo as eqs.(30) e (31) na eq. (29) obtêm-se:

$$
\begin{gathered}
{ }^{C} K_{E X}=\frac{f_{C s} x_{C s} \cdot k_{L i} \cdot \gamma_{L i}}{f_{L i} x_{L i} \cdot k_{C s} \cdot \gamma_{C d}} \\
{ }^{C} K_{E X}=\frac{x_{C s} \cdot k_{L i}}{x_{L i} \cdot k_{C s}}=\frac{f_{C s} \gamma_{L i}}{f_{L i} \gamma_{C s}}
\end{gathered}
$$

Neste caso, quando ${ }^{\mathrm{C}} \mathrm{Kex}$ é maior que 1 (um) o equilíbrio na equação (21) está deslocado para a direita, isto é, há preferência pela forma adsorvida existente no segundo membro da equação; quando ${ }^{{ }^{C}}$ Kex é menor que 1 (um) ocorre o inverso. Este coeficiente fornece uma medida quantitativa e experimentalmente acessível de seletividade de troca binária sob as condições pelo qual o experimento é executado. Este coeficiente pode ser usado como um índice para uma comparação de afinidade relativa de vários trocadores por cátions específicos.

A molalidade $(k)$ do $\mathrm{Li}^{+}$pode ser calculada pela diferença entre a $k_{C s}$ e a $k_{L i C l}$ adscionada (concentração na solução extratora estoque), assumindo que a conservação de carga resulta da troca 1:1. As frações molares do $\mathrm{Cs}^{+}$adsorvido (igual a 1 para a pasta de solo saturado com $\mathrm{CsCl}$ ) e $\mathrm{Li}^{+}$são calculados por:

$$
\chi_{C s}=\frac{\sigma_{O}}{\sigma_{\text {TOTAL }}} \quad \text { e } \quad \chi_{L i}=1-\chi_{C s}
$$


3.3.3 Remoção dos óxidos de ferro livre e amorfo da matéria nos solos ácricos. e.

A remoção dos óxidos de ferro livre e amorfo e da matéria seguiu a metodologia descrita por Camargo et al., 1986. Removidos os materiais cimentantes dos solos, procedeu-se à determinação das cargas elétricas repetindose a metodologia descrita no item 3.2 .5 com o objetivo de verificar o efeito dessas remoções no comportamento das cargas. 


\section{RESULTADOS E DISCUSSÃO}

Os resultados das análises químicas, físicas e mineralógicas para os solos estudados foram obtidos por Alleoni (1992) com os dados mais relevantes para o presente trabalho estando apresentados nas Tabelas $3,4,5$.

\subsection{Análises químicas e eletroquímicas}

A relação $\mathrm{SiO}_{2} / \mathrm{Al}_{2} \mathrm{O}_{3}$ (ki) é um bom indicador da dessilicatização do material e consequentemente do estádio de intemperismo (Benemma et al., 1970) sendo os valores 1,9-2,2 admitidos como limites superiores nos latossolos. Os solos estudados apresentaram valores bastante inferiores $(0,60-1,89)$ a esse limite, exceto a TE que teve esse índice próximo do limite superior, indicando importante dessilicatização e presença de gibbsita bem como estado menos avançado de intemperismo.

Entre os latossolos ácricos, o LRác- Guaíra apresentou menor ki, enquanto para as outras amostras este índice esteve próximo de 1,0 , demonstrando na sua fração argila um predomínio dos minerais caulinita e sesquióxidos de ferro e alumínio (Tabela 5).

Para todos os solos, mais da metade do ferro encontra-se na forma cristalina (livre), enquanto que as formas não cristalinas (amorfas) contêm, em média, apenas $4 \%$ do total. Em relação ao alumínio, as formas livres apresentaram variações de 11 a 17\% do total, o LUna ác-argare apresentou 


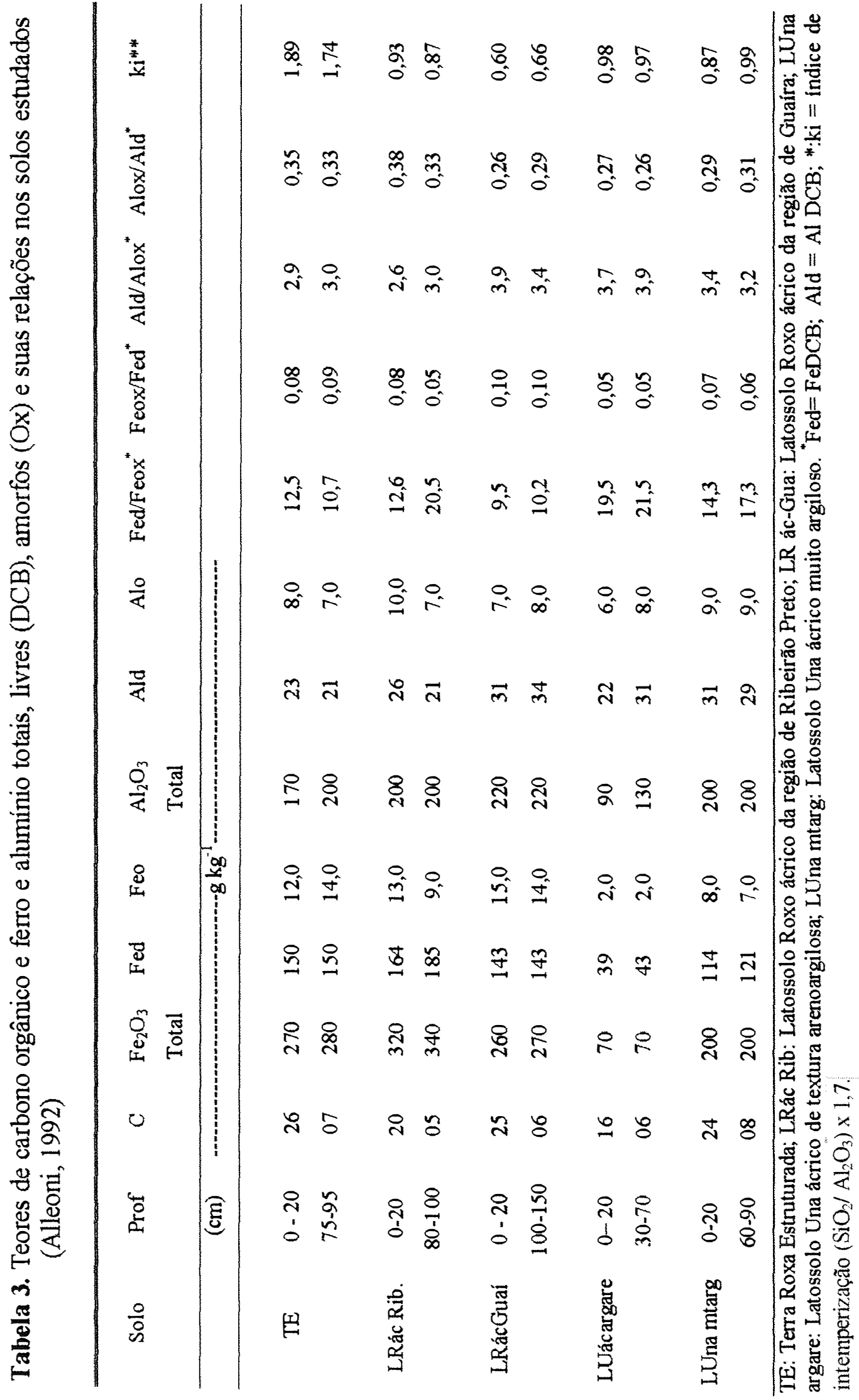


valores acima de $20 \%$ e $25 \%$ em superfície e em profundidade, respectivamente.

Os valores de $\mathrm{Fe}_{\mathrm{d}}$ (Tabela 3) variaram de 39 a $185 \mathrm{~g} \mathrm{~kg}^{-1}$ entre os solos, com os maiores valores para o LRác-Rib (164 e $\left.185 \mathrm{~g} \mathrm{~kg}^{-1}\right)$. TE $\left(150 \mathrm{~g} \mathrm{~kg}^{-1}\right)$ e LRácGua (143 $\mathrm{g} \mathrm{kg}^{-1}$ ), seguido do valor intermediário para o LUna.ác-mtarg (114 e $121 \mathrm{~g} \mathrm{~kg}^{-1}$ ) e de um valor menor, para o LUna ác-argare (39 e $43 \mathrm{~g} \mathrm{~kg}^{-1}$ ), nas duas profundidades (A e $\mathrm{B}$, respectivamente).

Os óxidos de ferro amorfos no solo LRác-Rib e no LUna ác-mtarg decresceram com a profundidade, o que parece mostrar a existência de uma relação entre eles e o carbono, concordando com Schwertmann et al., (1968), uma vez que os compostos orgânicos podem reter os óxidos de ferro, prevenindo ou retardando a sua cristalização, o que deve explicar em parte essa distribuição.

Os valores obtidos de $\mathrm{Fe}_{\mathrm{d}}$, indicam um acúmulo relativo de ferro oxidado associado com forte intemperismo, confirmados pela baixa relação de $\mathrm{Fe}_{\text {ox }} / \mathrm{Fe}_{d}<$ 0,1 (Tabela 3). Do ponto de vista das afirmações de Kämpf et al. (1988) e Santana (1984), que consideram que a relação de $\mathrm{Fe}_{\mathrm{ox}} / \mathrm{Fe}_{\mathrm{d}}<0,03$ em oxissolos como indicativo do predomínio das formas cristalinas, essas relações no presente estudo variaram de 0,05 a 0,09 (Tabela 3), podendo-se inferir que as formas amorfas ainda têm importância relevante nesses solos no que diz respeito ao intemperismo.

Ao se verificar o estado de intemperismo entre os solos, pode-se observar que a relação de atividade de $\mathrm{Al}\left(\mathrm{Al}_{\mathrm{ox}} / \mathrm{Al}_{\mathrm{d}}\right)$ foi maior para o $\mathrm{LR}$ ác-Rib, enquanto que a relação de $\mathrm{Fe}\left(\mathrm{Fe}_{\text {or }} / \mathrm{Fe}_{\mathrm{d}}\right)$ foi maior para o LR ác-Gua, podendo considerar-se que estes solos recebem na superficie uma quantidade significativa de matéria orgânica para solubilizar os óxidos de $\mathrm{Fe}$ e de $\mathrm{Al}$ e transformá-los numa forma mais amorfa (Sakurai et al., 1991). Entre os latossolos Una, essa relação foi maior para o de textura arenoargilosa. Os solos TE e LRác-Rib apresentaram relações $\mathrm{Al}_{\text {ox }} / \mathrm{Al}_{\mathrm{d}}$ de 0,34 e 0,36 , respectivamente, que são maiores do que a dos demais solos, demonstrando ainda uma alta atividade de $\mathrm{Al}$. 
Das características eletroquímicas medidas pode-se verificar que, em todos os solos estudados (Tabela 4) os $\Delta \mathrm{pHs}$ sempre foram negativos na superfície e, nos horizontes $\mathrm{B}$, estiveram próximos de zero ou positivos, como no caso do LRác-Rib, LRác-Gua e LUna ác-argare. Esta reversão no balanço de carga, isto é, predomínio das cargas positivas sobre as negativas, em profundidade, indica solos altamente intemperizados com índices de intemperização (ki) apresentaram-se inferiores ou próximos a 1,0 .

A matéria orgânica na camada superficial de todos os solos, teve uma grande participação (Tabela 3), uma vez que os valores do PESN foram bastante baixos variando de 3,35 a 3,65, enquanto que em profundidade tais valores foram superiores, exceto para TE que se manteve constante o que era de se esperar na medida de este solo apresentar ki bem mais elevado que os demais. Destacam-se os elevados valores de PESN no horizonte B para os demais solos $(5,50$ a 6,05$)$ decorrente da menor participação de matéria orgânica e do efeito mais pronunciado dos óxidos de ferro e alumínio.

Verifica-se que o PESN não se igualou ao $\mathrm{pH}$ do solo em água mesmo nos solos com material ácrico, fato este que, segundo Hendershot \& Lavkulich (1978), parece indicar que a química de superfície ativa ainda não atingiu o equilibrio de cargas. Observa-se também, que tanto o valor de $\mathrm{PESN}$ e do $\mathrm{pH}_{\mathrm{KCl}}$ no horizonte B apresentaram a mesma tendência, com forte característica anfotérica de tal forma que a diferença entre PESN e o pH do solo diminuiu com a idade do solo de um valor máximo de t0,4 para o LUna ác-argare para um mínimo de $-1,7$ na TE, concordando com as avaliações de Hendershot \& Lavkulich (1978 e 1979). Esta tendência, segundo estes autores, está relacionada ao aumento no conteúdo de sesquióxidos do horizonte $\mathrm{B}$. 


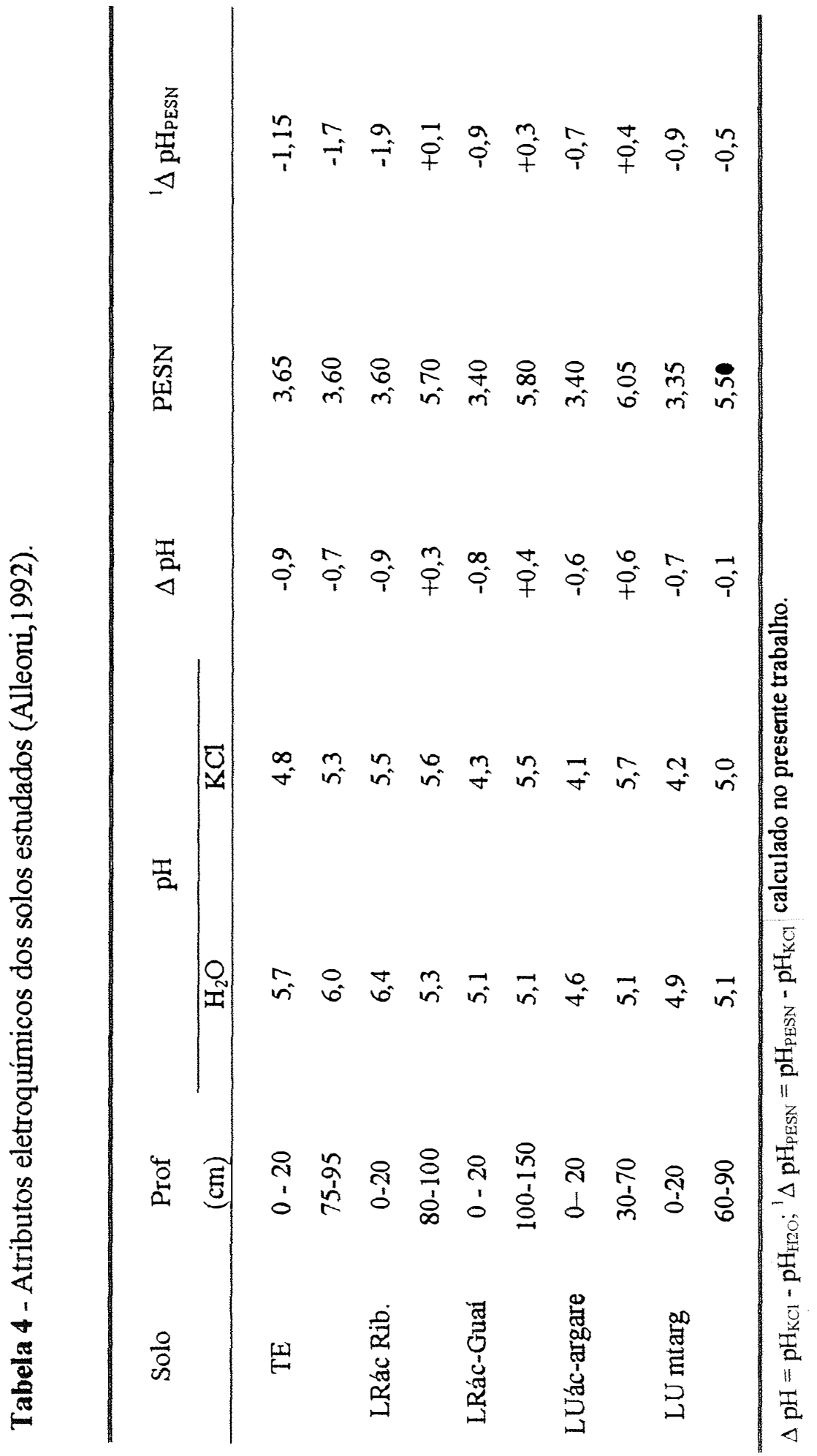




\subsection{Análises física e mineralógicas}

Análise fisica

Os valores da superficie específica (SE) foram baixos, (variação de 21 a 61 $\mathrm{m}^{2} / \mathrm{g}$ ), o que se deve à predominância de minerais cauliníticos e oxídicos na fração argila dos solos (Tabela 5). Nota-se que, para a maioria das amostras, os valores de SE da camada superficial apresentaram valores mais altos que em subsuperficie exceto, o LUna ác-argare que apresentou uma SE maior em profundidade observando-se também que, neste caso, o valor da relação \%C do horizonte $\mathrm{A} / \% \mathrm{C}$ do horizonte $\mathrm{B}$ foi menor, ou seja, 2,6 $\mathrm{m}^{2} \mathrm{~g}^{-1}$ enquanto que dos demais solos variou entre 3,0 e 4,2 .

Análise mineralógica da fração argila total.

Pelos resultados da análise térmica diferencial dos horizontes superficiais e subsuperficiais que se encontram sumarizadas na Tabela 5 e Figuras 1 a 6, a gibbsita e a caulinita, com reações endotérmica a $\pm 290^{\circ} \mathrm{C}$ e a $530^{\circ} \mathrm{C}$, respectivamente, foram os minerais dominantes em todas as amostras. Estes resultados foram semelhantes aos obtidos por Antonello (1978), Antonello et al., (1988) e Alleoni (1992). 


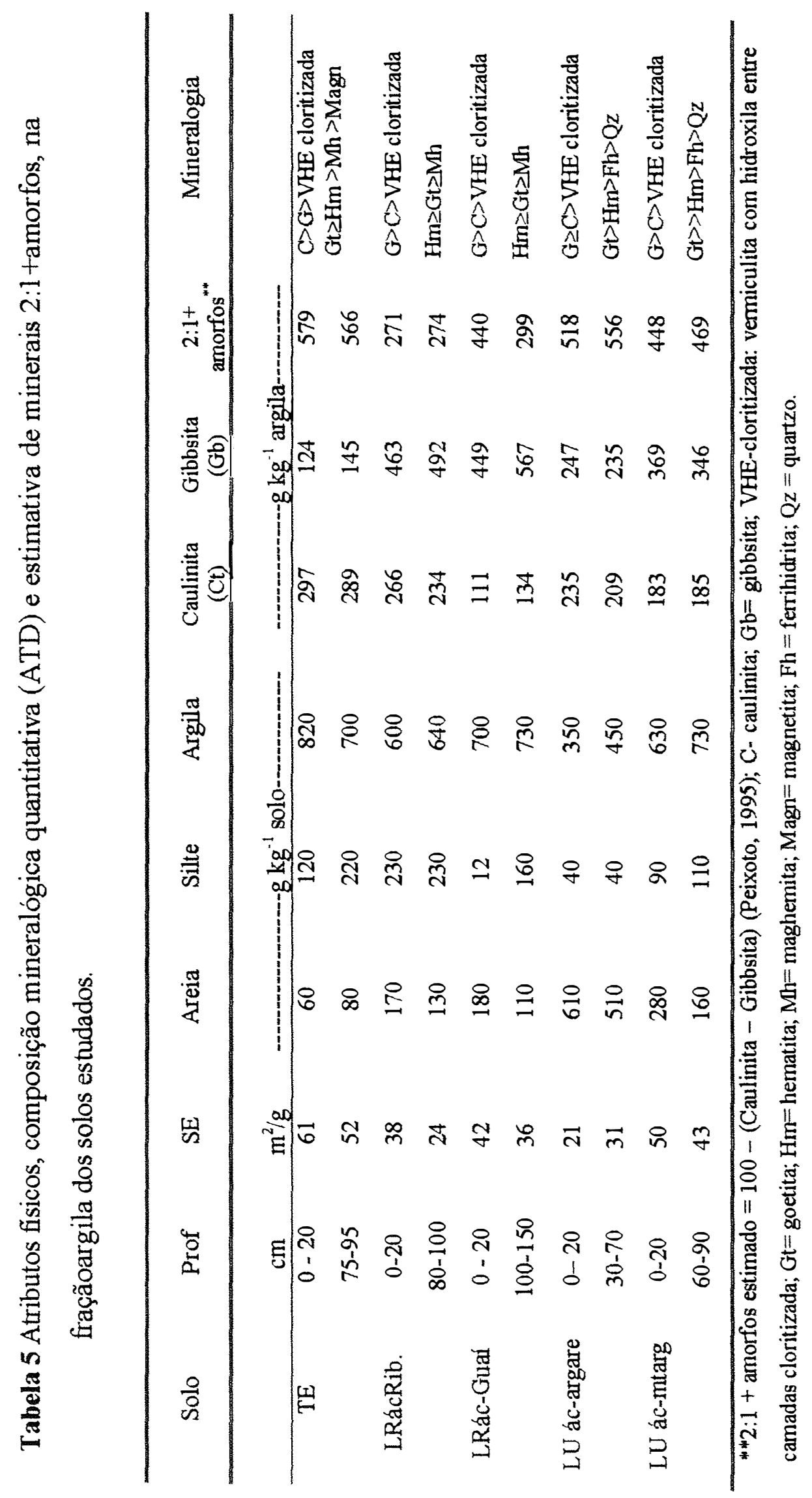




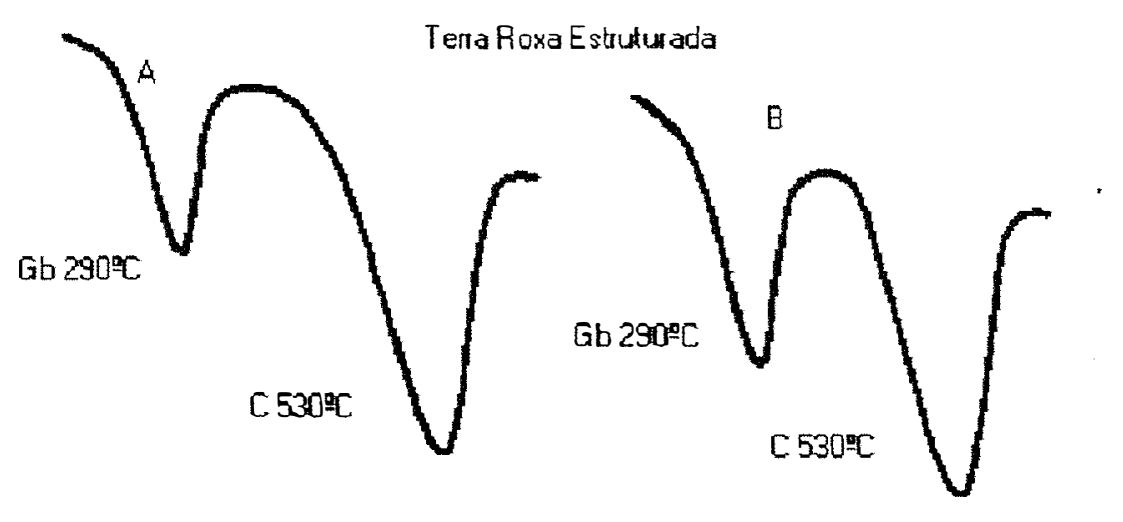

Figura 1- Análise térmica diferencial das frações de argila, isenta de ferro e saturadas com $\mathrm{Mg}$, dos horizontes superficial (A) e subsuperficial (B) da TE (C= caulinita; $\mathrm{Gb}=$ gibbsita)

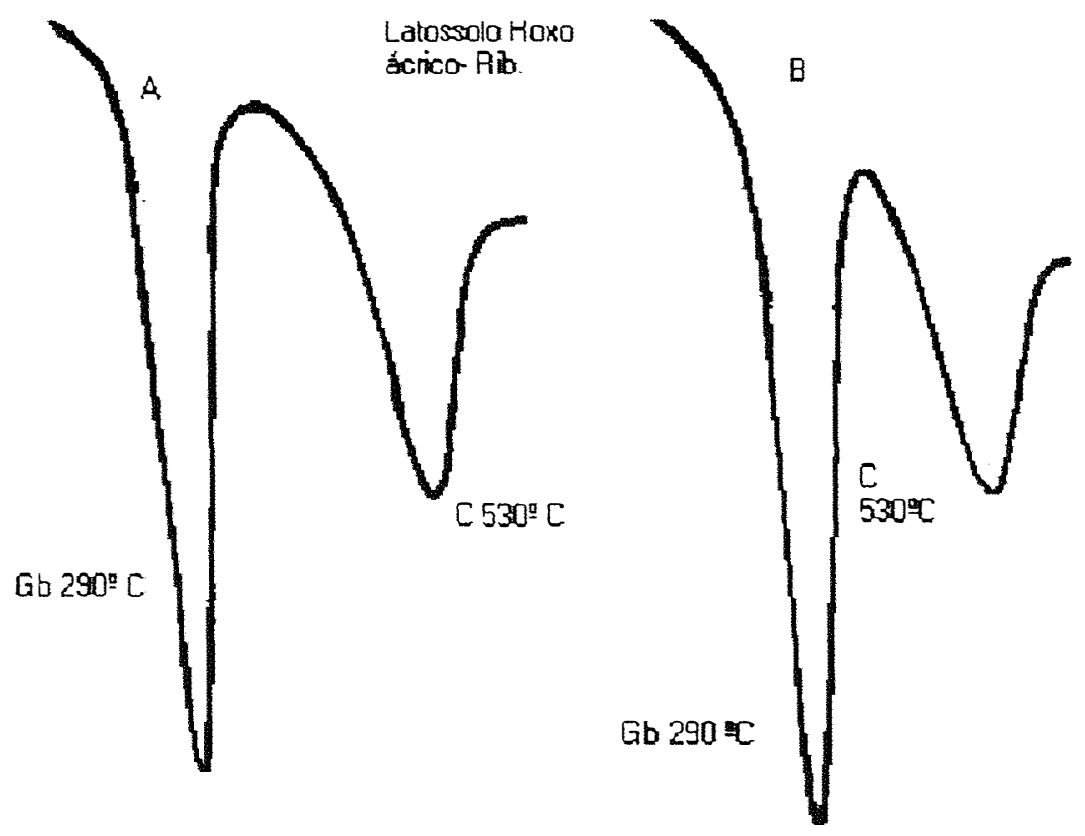

Figura 2- Análise térmica diferencial das frações de argila, isenta de ferro e saturadas com Mg, dos horizontes superficial (A) e subsuperficial (B) do LR ác-Rib. 


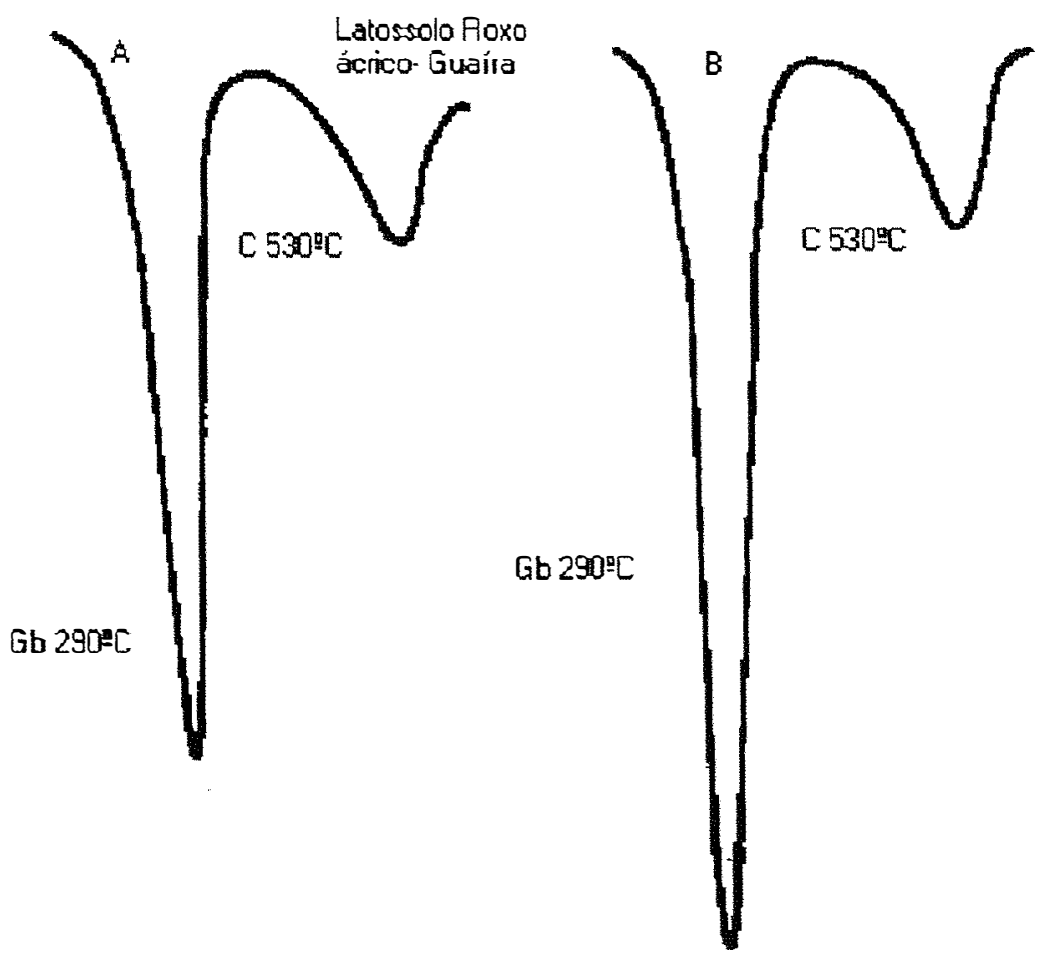

Figura 3- Análise térmica diferencial das frações de argila, isenta de ferro e saturadas com $\mathrm{Mg}$, dos horizontes superficial (A) e subsuperficial (B) do LR ác-Gua. 


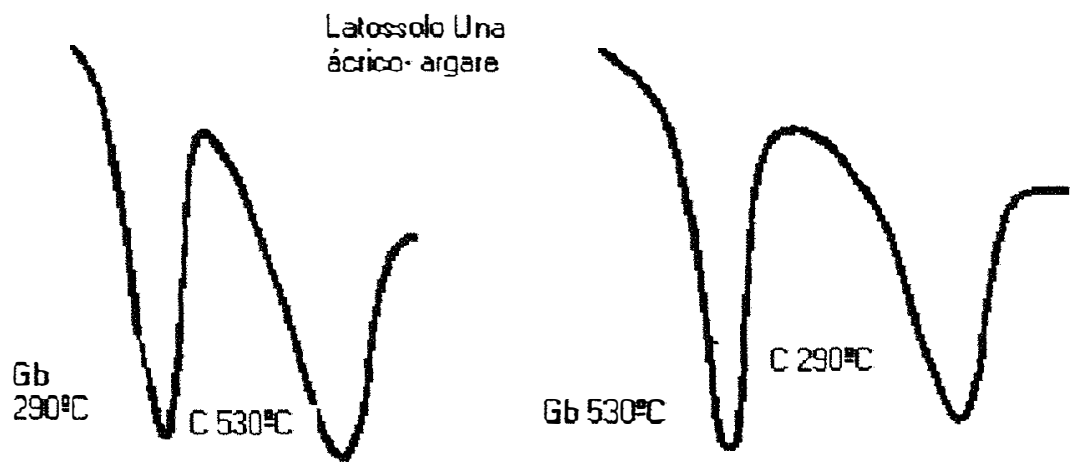

Figura 4- Análise térmica diferencial das frações de argila, isenta de ferro e saturadas com $\mathrm{Mg}$, dos horizontes superficial (A) e subsuperficial (B) do LUna ácargare.

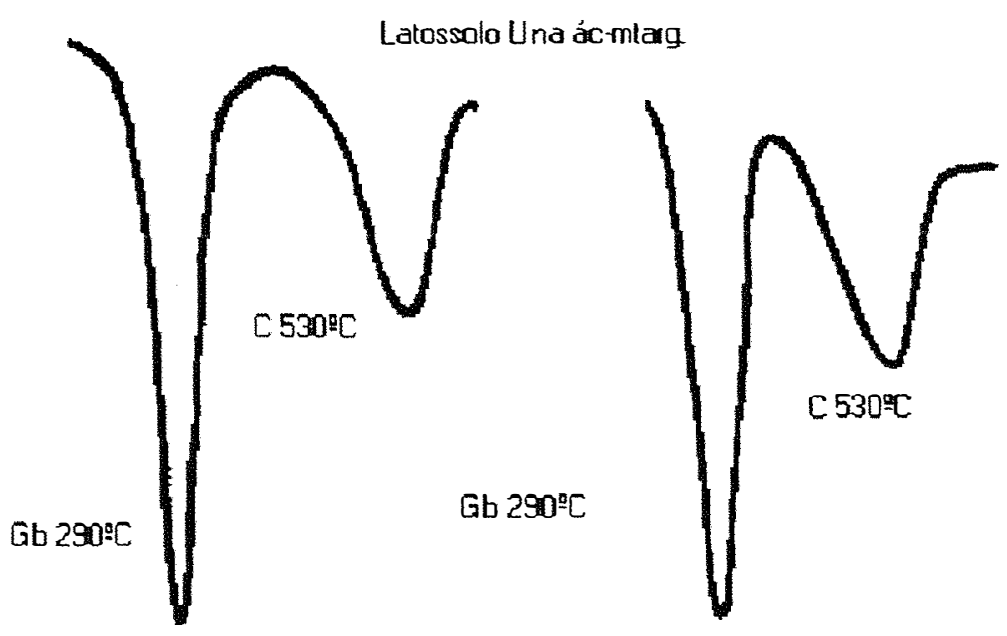

Figura 5- Análise térmica diferencial das frações de argila, isenta de ferro e saturadas com $\mathrm{Mg}$ 。 dos horizontes superficial (A) e subsuperficial (B) do LUna ác-mtarg. 
Os difratogramas da fração argila deferrificada dos horizontes superficial e subsuperficial dos solos estudados (Figuras 6 a 10), revelaram presença de caulinita $(7,20$ e $3,57 \AA)$ na TE seguida da gibbsita $(4,83$ - 4,34 $\AA)$ ao passo que, nos dois Latossolos Roxos ácricos de Ribeirão e de Guaíra e nos dois LUnas ácricos os picos de gibbsita sobre a caulinita foram mais intensos, corroborando cøm os índices de intemperização e com a análise térmica diferencial. Estes resultados estão em concordância com Weaver (1974), Moniz \& Jackson (1967) e Motchi (1977) que constataram que na fração argila de alguns latossolos predomina a caulinita e em outros a gibbsita, isso demonstra que os latossolos apesar de altamente intemperizados, apresentam diferentes estádios de intemperismo, sendo o grau de intemperização proporcional aos teores de gibbsita (Rodrigues \& Klamt, 1978).

Observou-se ainda, traços de minerais interestratificados $(27-28 \AA)$ e de minerais 2:1 individualizados em quase todos os solos, exceto nos DRXs da TE que foi revelado traços desses minerais.

Os difratogramas da fração argila da TE saturada com magnésio revelaram associação da caulinita $(7,20 \AA)$ com a clorita $(7,15 \AA)$ e de esmectita /vermiculita $(14,1 \AA)$, VHE (12 $\AA)$ e mica (10 e $5 \AA$ ); com a glicolagem foram observadas difrações de minerais expansíveis da esmectita $(17,6 \AA)$ e da vermiculita (14,5 $\AA$ ), enquanto que a da mica manteve-se inalterada. Os difratogramas das amostras saturadas com potássio à temperatura ambiente revelaram difrações de $14 \AA$ da VHE cloritizada; esmectita $(12,2 \AA)$ e mica $(10$ e $5,0 \AA)$; a $350^{\circ} \mathrm{C}$ os picos da VHE cloritizada (14 $\AA$ ) manteve-se inalterada enquanto o pico da esmectita de $14,1 \AA$ colapsou para $10 \AA$; a $550^{\circ} \mathrm{C}$ os picos da esmectita $(12,2 \AA)$ e da clorita ( $3^{\mathrm{a}}$ ordem, $3,54 \AA$ ) permaneceram inalterados. 

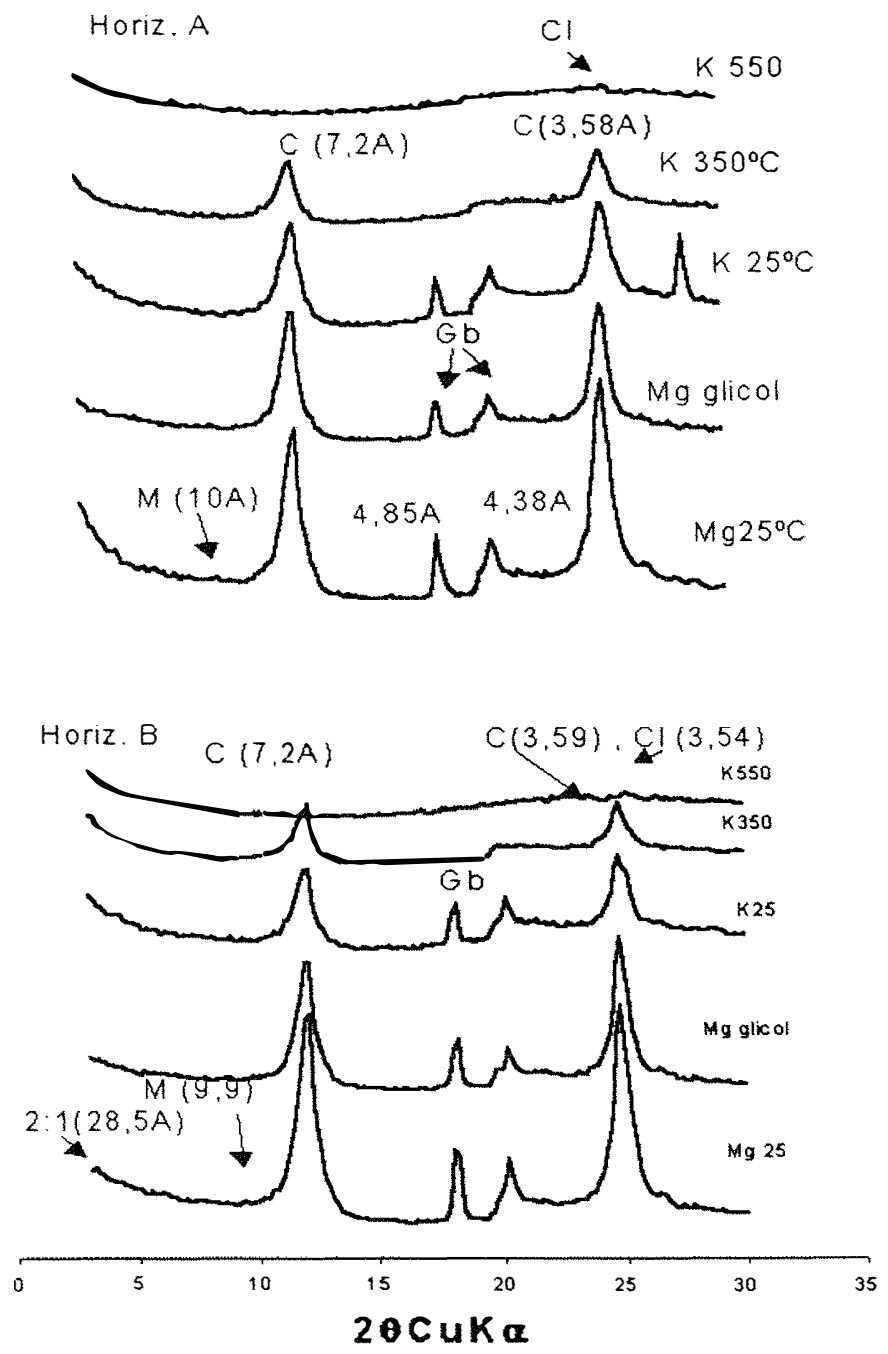

Figura 6 Difratogramas de raios- $X$ da fração argila deferrificada das camadas superficial (A) e subsuperficial da Terra Roxa Estruturada (C= caulinita; $\mathrm{Gb}+$ gibbsita ; $\mathrm{Cl}=$ clorita $)$. 

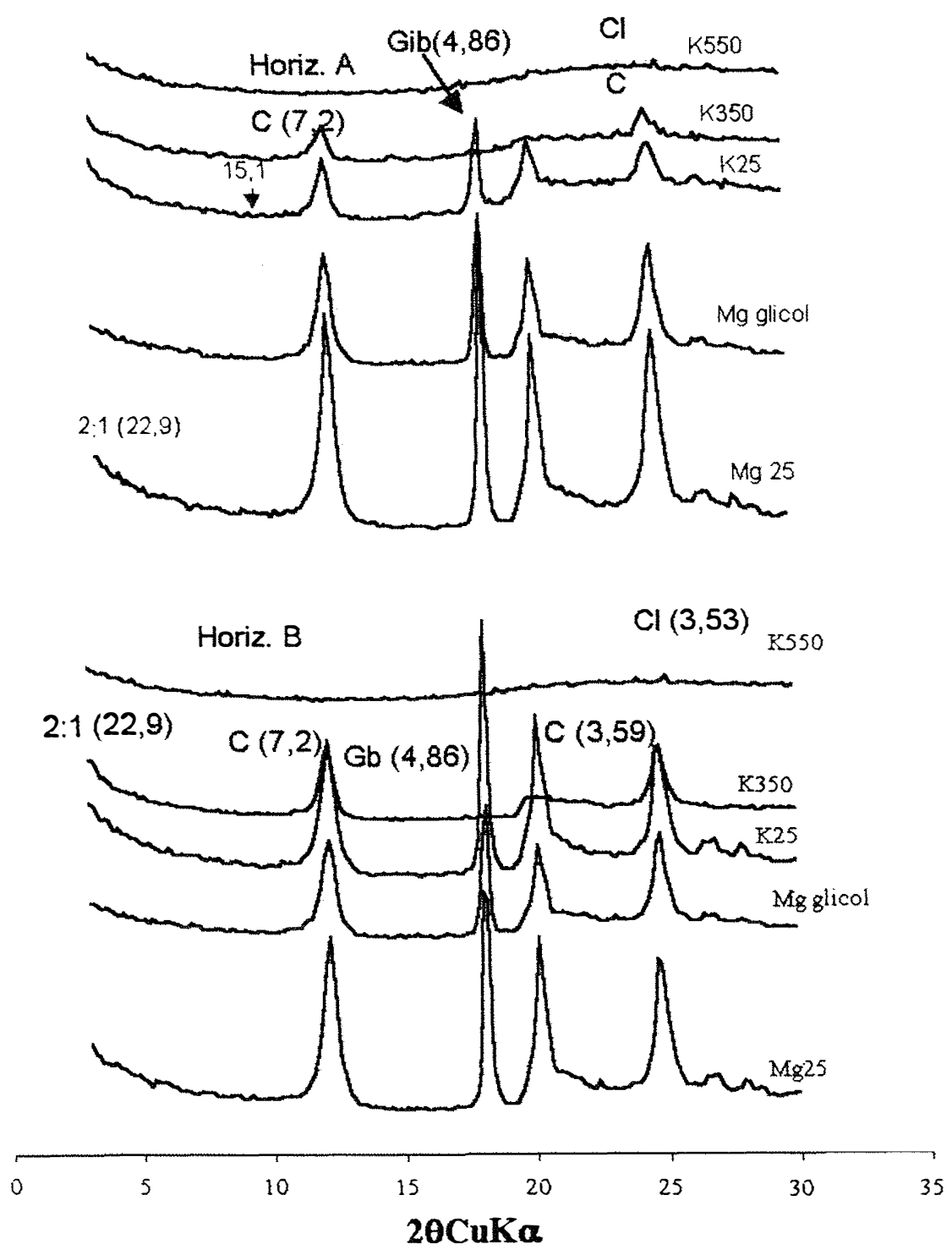

Figura 7 Difratogramas de raios- $X$ da fração argila deferrificada das camadas superficial (A)e subsuperficial (B) do Latossolo Roxo ácrico-Rib (C= caulinita; $\mathrm{Gb}=$ Gibbsita; $\mathrm{Cl}$ clorita). 

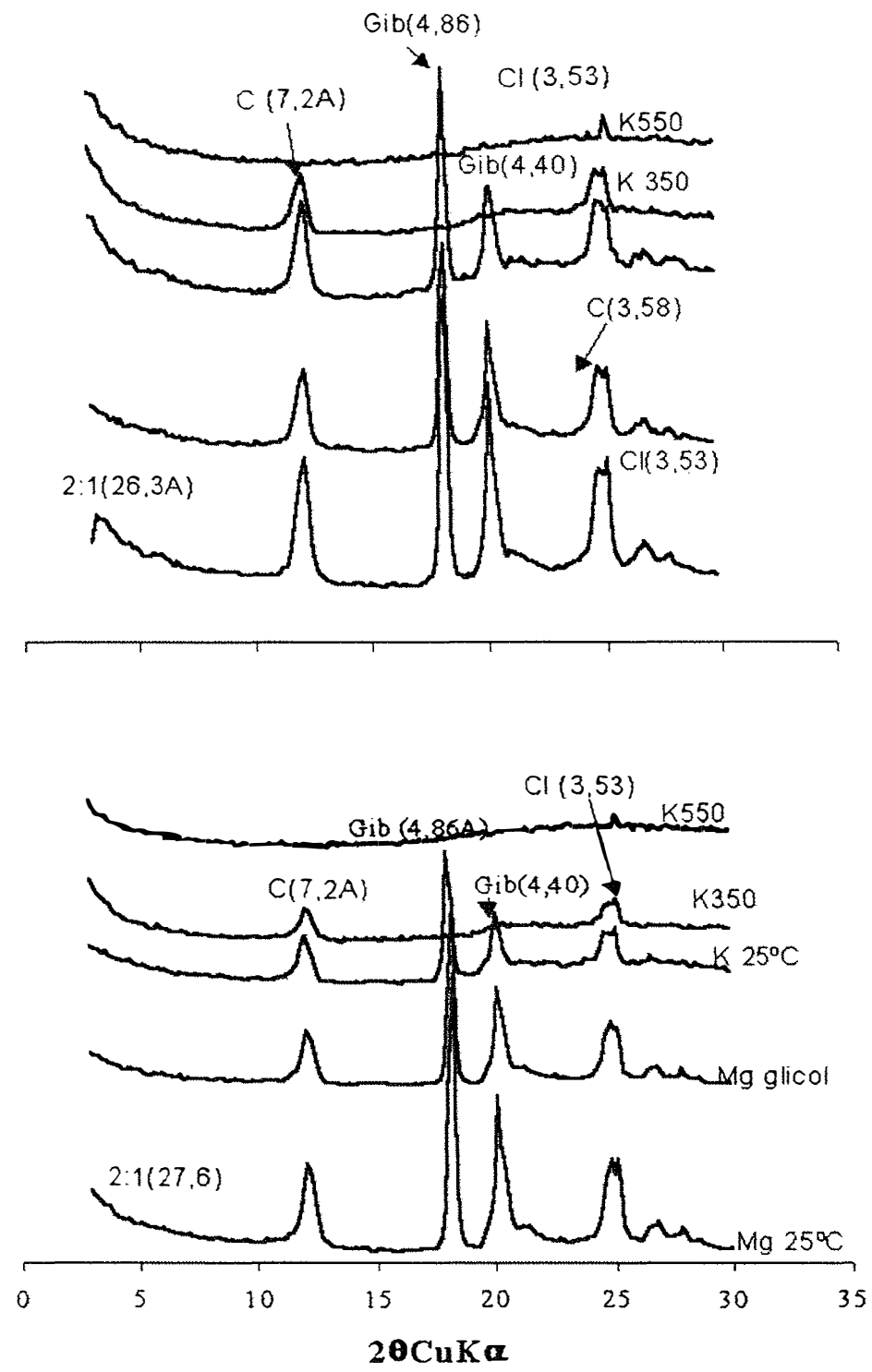

Figura 8 Difratogramas de raios-X da fração argila deferrificada das camadas superficial (A)e subsuperficial (B) do Latossolo Roxo ácrico-Gua $(\mathrm{C}=$ caulinita; $\mathrm{Gb}=$ gibbsita; $\mathrm{Cl}=$ clorita; $\mathrm{Cl}-\mathrm{VHE}=$ vermiculita aluminosa cloritizada). 


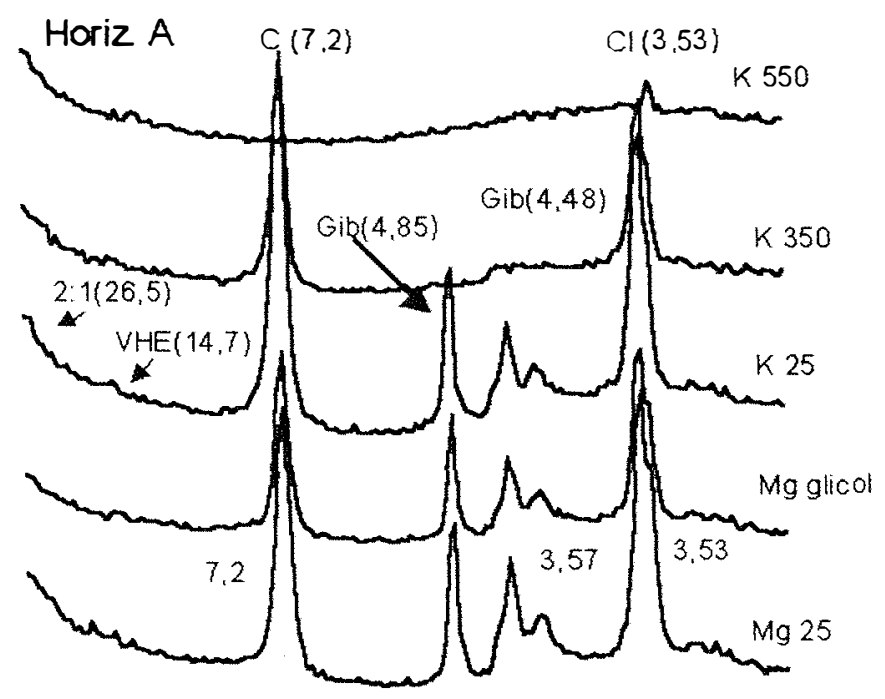

Horiz B

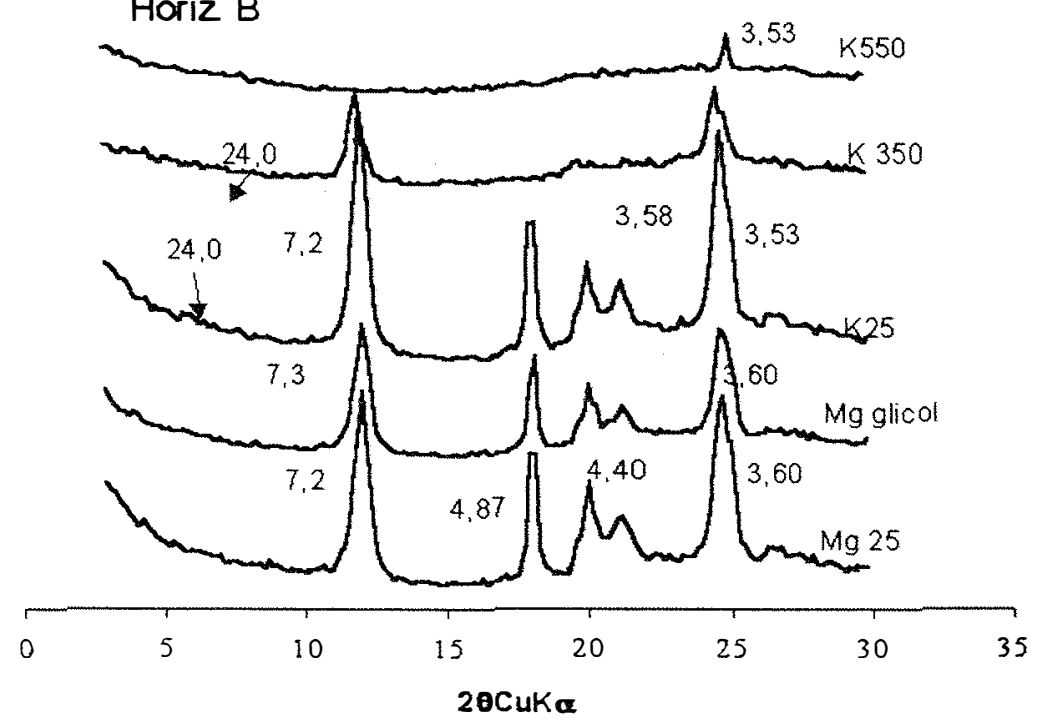

Figura 9 Difratogramas de raios- $\mathrm{X}$ da fração argila deferrificada das camadas superficial (A) e subsuperficial (B) do Latossolo Una ácrico-argare (C= caulinita; $\mathrm{Gib}=$ gibbsita; $\mathrm{Cl}=$ clorita; $\mathrm{Cl}-\mathrm{VHE}=$ vermiculita aluminosa cloritizada). 

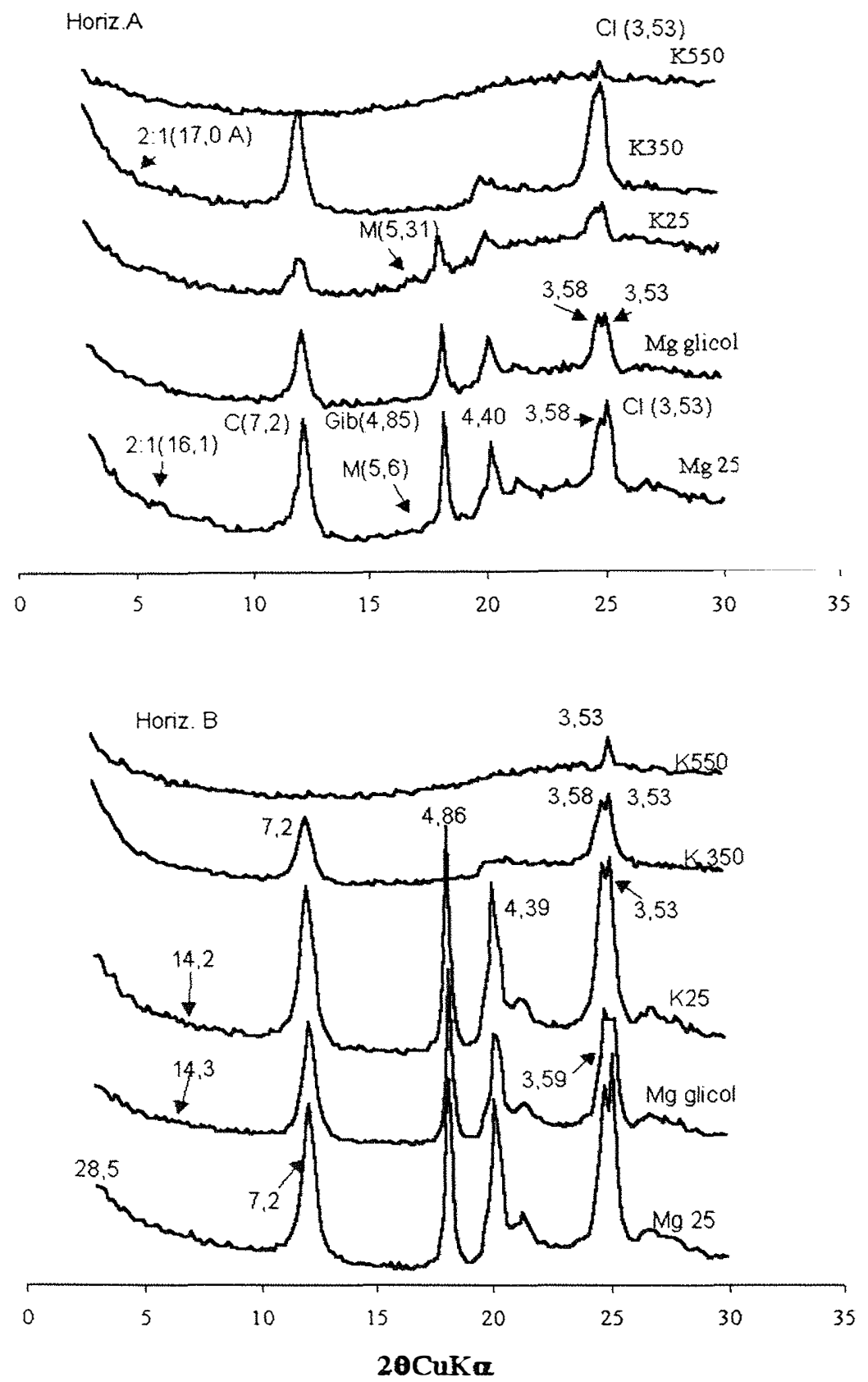

Figura 10 Difratogramas de raios- $X$ da fração argila deferrificada das camadas superficial (A) e subsuperficial (B) do Latossolo Una ácrico-mtarg. $(\mathrm{C}=$ caulinita; $\mathrm{Gb}=$ gibbsita; $\mathrm{Cl}=$ clorita; $\mathrm{Cl}-\mathrm{VHE}=$ vermiculita aluminosa cloritizada). 
Os difratogramas da fração argila do LR ác-Rib revelaram na amostra saturada com magnésio a $25^{\circ} \mathrm{C}$ difrações de $15,5 \AA$ (vermiculita/ esmectita), de 10 e $5 \AA$ (mica); com a glicolagem a difração de 15,5 expandiu par 19,6 $\AA$; difrações de $12 \AA, 18,8 \AA$ (esmectita), $14 \AA$ (VHE cloritizada) e $10 \AA$ (mica) foram reveladas nos tratamentos saturados com potássio à temperatura ambiente; a $350^{\circ} \mathrm{C}$ ocorreu colapso do pico de 14 para $12,2 \AA$ (VHE cloritizada) e a $550^{\circ} \mathrm{C}$ o pico de $3^{\mathrm{a}}$ ordem da clorita $(3,54 \AA)$ manteve-se inalterado.

Os difratogramas (Figura 8) da fração argila deferrificada dos dois horizontes do LR ác-Gua revelaram traços de minerais interestratificados $(27,2 \AA)$, clorita $(3,53 \AA)$ associada ao pico de $2^{\mathrm{a}}$ ordem da caulinita $(3,59 \AA)$; com a glicolagem, o pico da caulinita diminuiu de intensidade; na saturação com potássio e aquecidos os picos da clorita $(3,53 \AA)$ manteve-se inalterado nas duas profundidades. Foram também observadas presença de VHE $(14,7 \AA)$ e da clorita $(7,15$ e $3,54 \AA)$ associada à caulinita $(7,2$ e $3,52 \AA)$; com a glicolagem foram mantidos picos menos intensos de 14 e 7,3 $\AA$; na saturação com potássio e aquecimento a clorita manteve-se inalterada $(3,53 \AA)$.

Nos difratogramas (Figura 9) da fração argila deferricada do LUna ácargare foram revelados traços de minerais interestratificados $(26,5 \AA)$ e de vermiculita/esmectita $(14,7 \AA)$ nos tratamentos saturados com potássio a $25^{\circ} \mathrm{C}$, a $350^{\circ} \mathrm{C}$ colapsamento para $12,2 \AA$; a $550^{\circ} \mathrm{C}$ foram observados difrações de $3,53 \AA$ nas duas profundidades, com maior intensidade na superficie em relação à subsuperficie. Nos difratogramas (Figura 14) da fração argila isenta de ferro livre e amorfo saturada com magnésio e glicolada foram também reveladas difrações de $14,7 \AA$ (vermiculita); com a saturação de potássio e aquecimento a 350 e $550^{\circ} \mathrm{C}$ foi mantida a difração de $3^{\mathrm{a}}$ ordem $(3,53 \AA)$ da clorita.

Nos difratogramas da fração argila deferricida (Figura 10) do LUna ác-mtarg foram revelados, na saturação com magnésio, traços de minerais interestratificados com distância interplanar de $28,6 \AA$ e de esmectita $(16,1 \AA)$ e difração de $17,0 \AA$ na saturação 
com potássio e com aquecimento a 350 e $550^{\circ} \mathrm{C}$. Difração de clorita $(3,53 \AA)$ de $3^{\mathrm{a}}$ ordem de mesma intensidade foi observada em todos os tratamento nas duas profimdidades.

A presença de picos de 14,0 (VHE) e 3,53 (clorita) ^ caracterizam como argilominerais do tipo 2:1 VHE cloritizada pedogênica segundo considerações de Jackson (1963; 1964), e forma-se pela precipitação de hidróxidos de alumínio polimerizados e sesquióxidos de ferro nos espaços interlaminares das vermiculitas ou das montmorilonitas, os quais confere grande estabilidade à VHE que permanece sob esta forma nesses solos. A presença de interestratificados têm sido reportada por vários pesquisadores (Weed \& Nelson, 1962); Moura Filho \& Buol, 1972); Möller \& Klamt, 1982; Fontes (1990); Alleoni (1992); Kämpf et al., (1995) fazendo supor ser a presença desses minerais mais uma constante dos latossolos do que uma exceção.

Com os índices de intemperismo e da análise mineralógica verifica-se o predomínio de caulinita e sesquióxidos de ferro e alumínio na fração argila destes solos e segundo Alleoni (1992) a classificação dos mesmos é a seguinte: TE: caulinítico não sesquioxídico; LR ác-Rib, LUna ác-mtarg e LUna ác-argare: cauliníticos sesquioxídicos; LRác- Gua: gibbsitíco sesquioxídico.

Identificação de óxidos de ferro na fração argila.

Por DRX, constatou-se que nas argilas tratadas com NaOH 5M (Norrish \& Taylor, 1961 modificado por Kämpf \& Schwertmann, 1982), a difração de goetita e de hematita bem como a presença de quartzo foram evidenciados (Figuras 11 a 15) pela eliminação dos argilominerais e concentração dos óxidos de ferro.

Os difratogramas de raios $\mathrm{X}$ revelaram que em ambos os horizontes da TE (Figura 11), difrações de hematita 3,$66 ; 2,68 ; 2,50 ; 2,19 ; 2,08 \AA$ e o de goetita 4,$13 ; 3,49 ; 2,69 ; 2,18$; e $1,69 \AA$; a difração de $2,50 \AA$ de ambos os horizontes 
apresentou intensidade mais elevada em relação à difração de $2,68 \AA$ da hematita na subsuperficie devido à presença de maghemita $(2,93 \AA)$.

Nos latossolos roxos ácricos Ribeirão e Guaira os respectivos difratogramas (Figuras 12 e 13$)$ mostraram que a hematita $(3,66 ; 2,69 ; 2,50 ; 2,19$; 2,$08 ; 1,83$ e $1,60 \AA$ ) foi a forma de óxido de ferro predominante nas duas profundidades com difração de maior intensidade na distância interplanar de

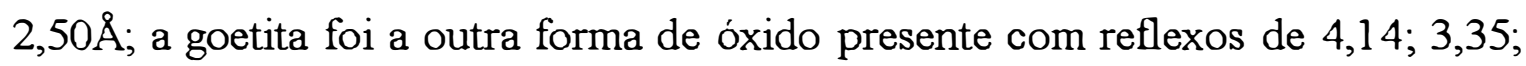
2,$69 ; 2,03$ e 1,68 $\AA$ com difração mais intensa no pico de 1,68 $\AA$. Observaram-se também, associações de maghemita com hematita/goetita nos dois solos; a maghemita encontra-se presente com maior intensidade no LR ác-Rib na subsuperfície ao passo que, no LR ác-Gua ocorreu nas duas profundidades.

Nos latossolos Unas ác-argare e ác-mtarg, os difratogramas (Figuras 14 e 15) indicaram que a forma goetítica predominou sobre as hematítica nas duas profundidades. Os dois solos apresentaram, na superficie, goetita com reflexos de $(4,13,2,45,2,27,2,23,2,19,2,121,76$ e $1,65 \AA)$ com maior intensidade no pico de 2,23 e 2,12 $\AA$ em ambos os solos. As distâncias interplanares (d) dos óxidos cristalinos na hematita $(3,66 ; 2,68 ; 2,50$ e $2,19 \AA)$ e na goetita $(4,13 \AA)$ nos argilominerais do solo são inferiores às distâncias interplanares da hematita $(3,69$; $2,70 ; 2,52 ; 2,21 \AA)$ e da goetita $(4,15 \AA)$ padrão, indicando substituição isomórfica do ferro por alumínio na estrutura dos óxidos de ferro nas argilas (Janot \& Gibert, 1971).

A presença e a distribuição de goetita e hematita nos LUnas ácricos, sugerem que a maior concentração de compostos orgânicos, 16 e $21 \mathrm{~g} \mathrm{~kg}^{-1}$, nos respectivos horizontes superficiais dos citados solos (Tabela 3) parece favorecer a formação de goetita em relação à hematita (Schwertmann, et al. 1968). 

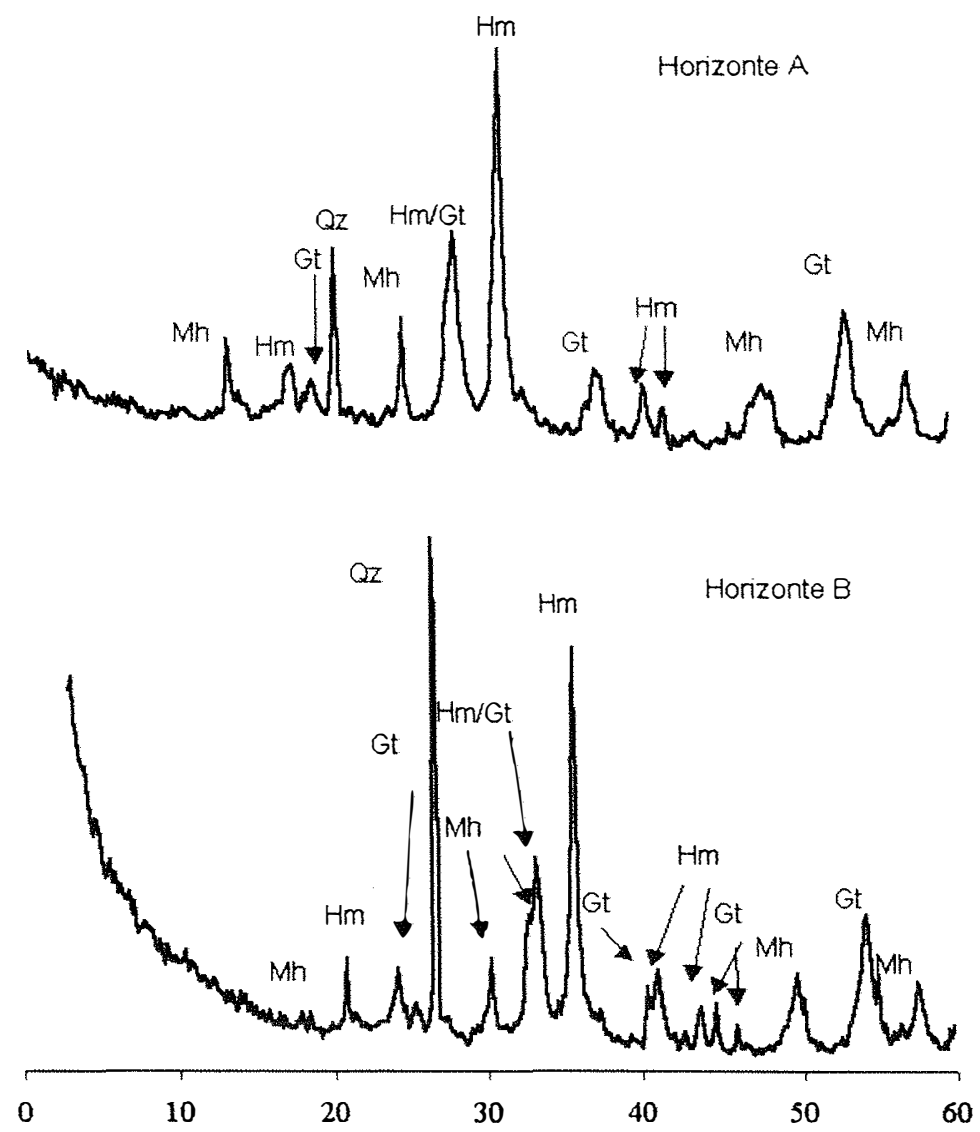

Figura 11 Difratogramas de raios $X$ dos óxidos de ferro da camada superficial ( A) e subsuperficial (B) da TE. ( $\mathrm{Gt}=$ goetita; $\mathrm{Hm}=$ hematita; $\mathrm{Mh}=$ maghemita; $\mathrm{Qz}$ $=$ quartzo). 


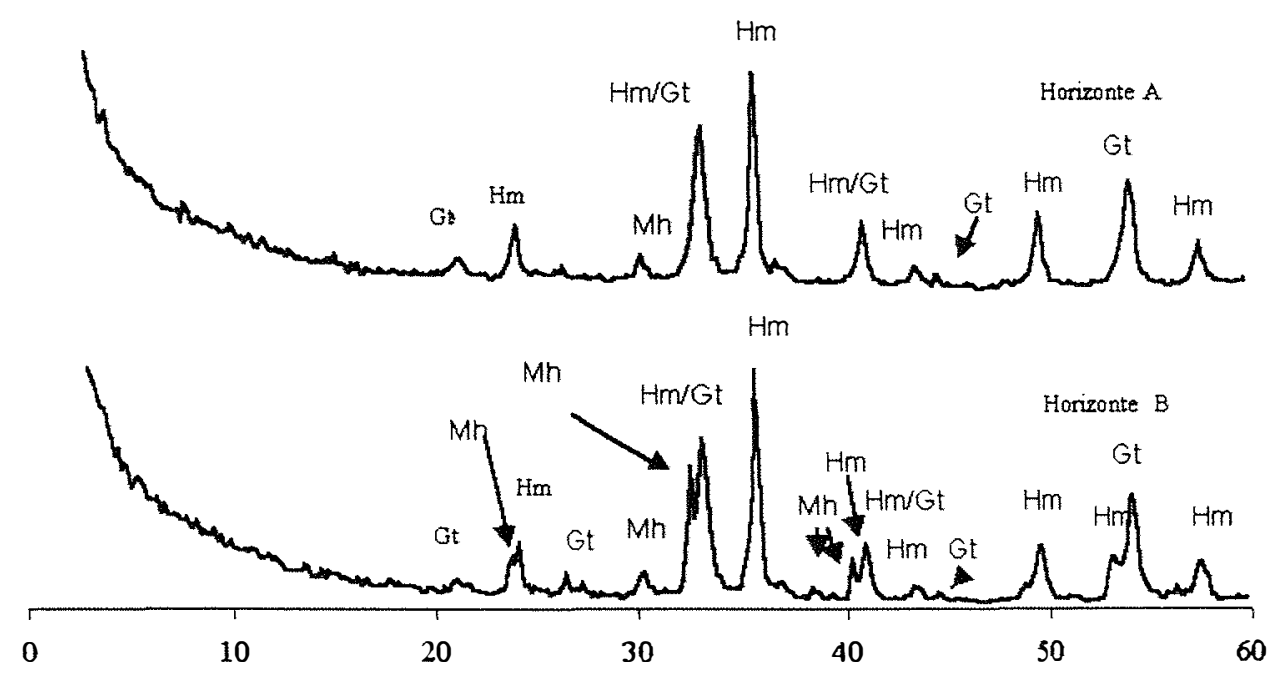

$2 \theta \mathrm{CuK} \alpha$

Figura 12 Difratogramas de raios $X$ dos óxidos de ferro da camada superficial (A) e subsuperficial (B) da LR ác-Rib (Gt= goetita; $\mathrm{Hm}=$ hematita; $\mathrm{Mh}=$ maghemita; $\mathrm{Qz}=$ quartzo). 


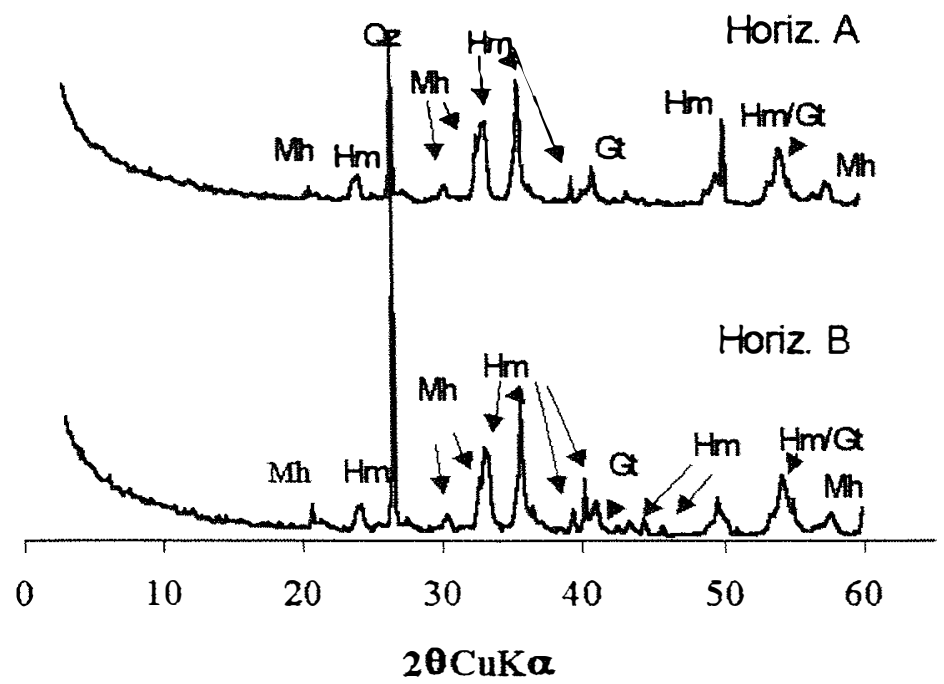

Figura 13 Difratogramas de raios $X$ dos óxidos de ferro da camada superficial ( A) e subsuperficial (B) da LR ác-Gua. ( $\mathrm{Gt}=$ goetita; $\mathrm{Hm}=$ hematita; $\mathrm{Mh}=$ maghemita; $\mathrm{Q} z=$ quartzo). 

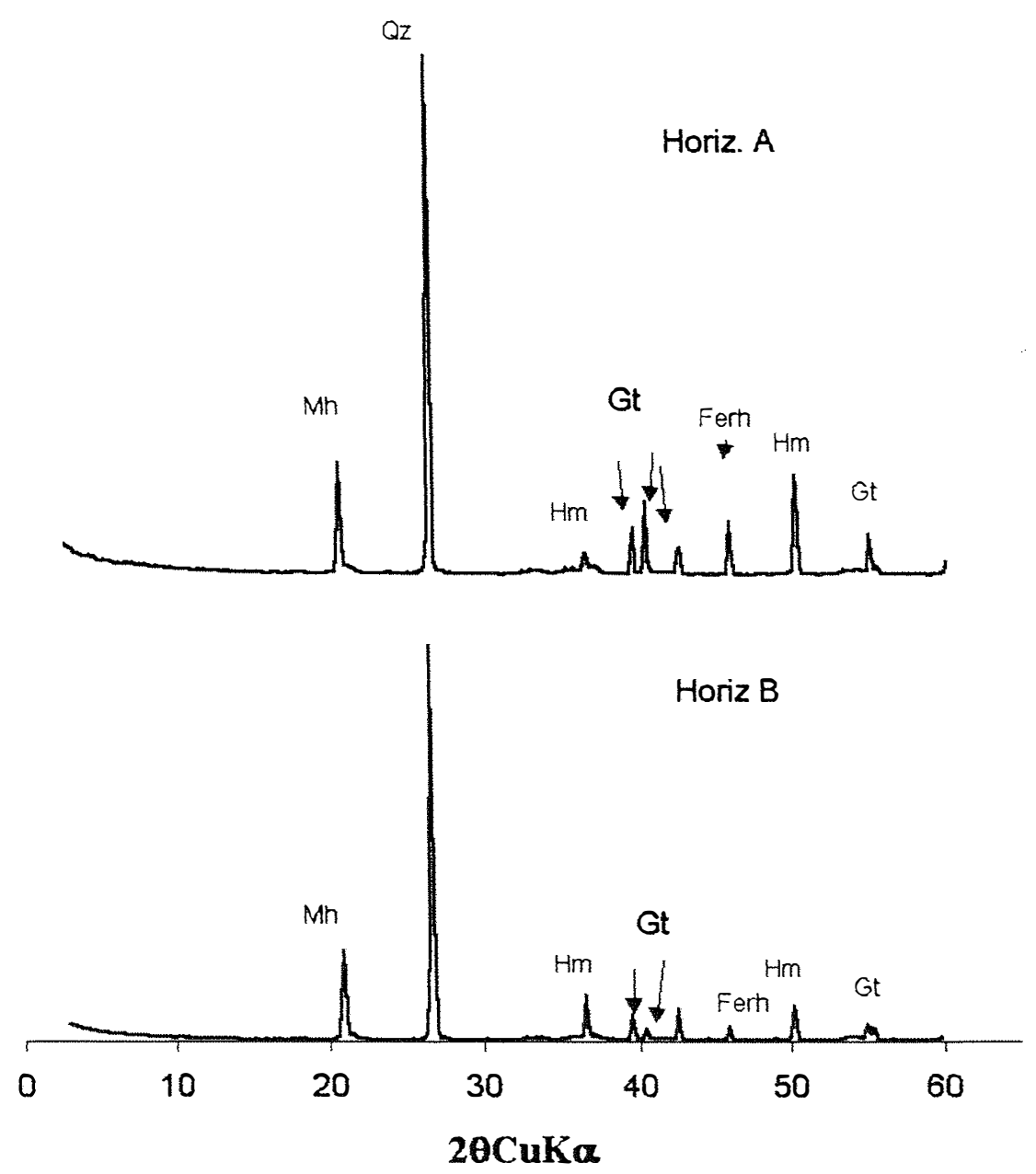

Figura 14 Difratogramas de raios $X$ dos óxidos de ferro da camada superficial ( A) e subsuperficial (B) da LUna ác- argare (Gt= goetita; $\mathrm{Hm}=$ hematita; $\mathrm{Mh}=$ maghemita; $\mathrm{Qz}=$ quartzo). 


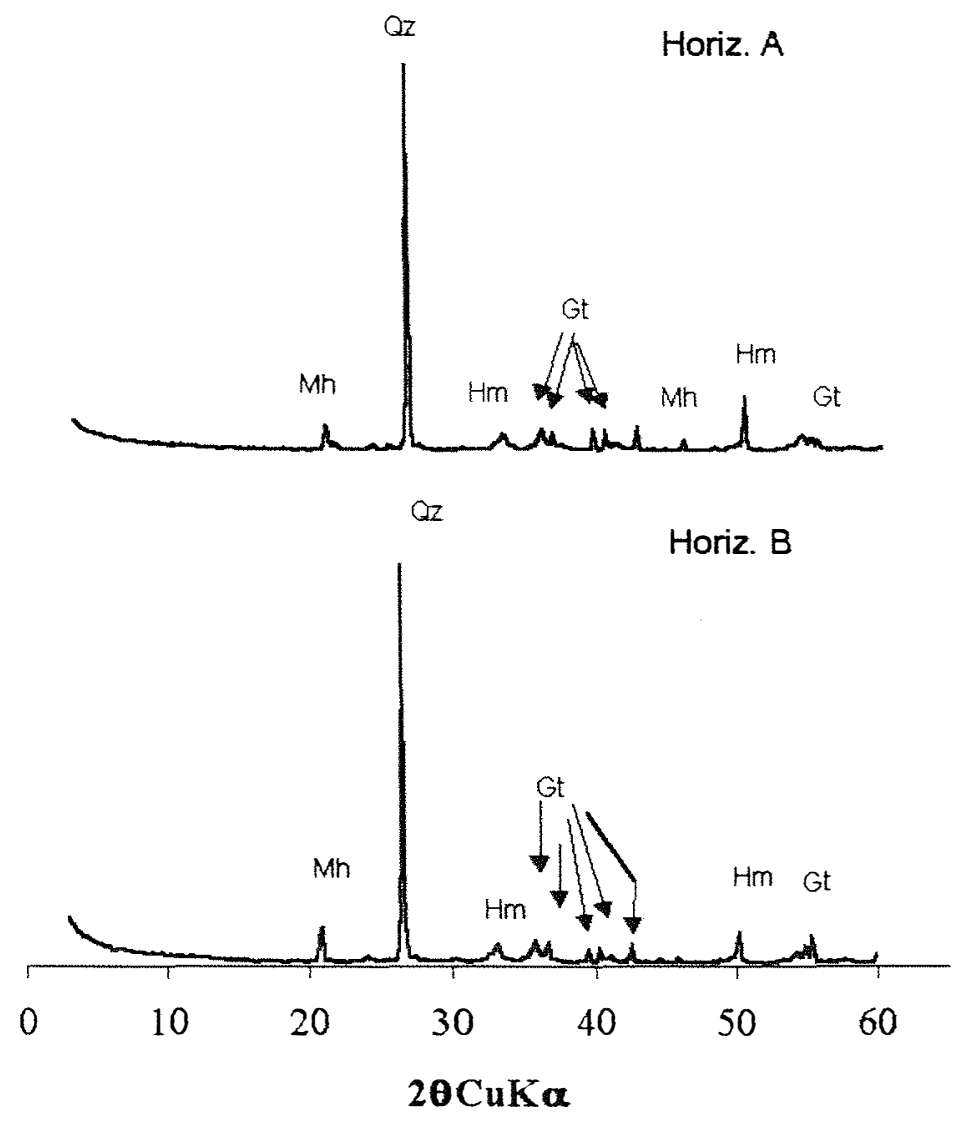

Figura 15 Difratogramas de raios $X$ dos óxidos de ferro da camada superficial (A) e subsuperficial (B) da LUna ác- mtarg. ( $\mathrm{Gt}=$ goetita; $\mathrm{Hm}=$ hematita; $\mathrm{Qz}=$ quartzo). 
No entanto, foi também observada presença de ferrihidrita, precursora da hematita, com difração de 1,97 $\AA$ nas duas profundidades do LUna ác-argare e na superfície do LUna ác-mtarg. Segundo Campbell \& Schwertmann (1984), a ferrihidrita é o principal componente amorfo dissolvido pelo oxalato de amônio, a qual está sempre associada com materiais orgânicos. Presumindo-se que as concentrações de compostos orgânicos nos citados horizontes sejam consideradas de médias a alta e, o ferro liberado venha ser complexado, conduzindo à estabilização da ferrihidrita que por sua vez, preveniria a coalescência das esferas oxídicas para não formar a hematita (Schwertmann et al., 1984; Schwertmann \& Latham, 1986) tornando favorável à formação da goetita (Schwertmann \& Taylor, 1977).

\subsection{Medida das cargas permanentes, variáveis e totais pelo método da adsorção de césio em uma Terra Roxa Estruturada e quatro solos ácricos originais.}

Os valores medidos da carga variável $\left(\sigma_{\mathrm{H}}\right)$ e permanente $\left(\sigma_{\mathrm{O}}\right)$ e total $\left(\sigma_{\mathrm{TOT}}\right)$ para os cinco solos investigados estão na Tabela 6. De acordo com o método de adsorção de césio, o valor medido de $\left(\sigma_{0}\right)$ seria igual em magnitude mas de sinal oposto à carga permanente efetiva. Em virtude de não se medir o íon cloreto a adsorção aniônica sobre os grupos de superficie ionizável foi desconsiderada conforme Anderson \& Sposito (1991), o valor absoluto de $\sigma_{\mathrm{H}}$ não pode ser determinado do valor de $\sigma_{\mathrm{H}}$ sozinho. Assim, se $\sigma_{\mathrm{O}}$ é a carga estrutural efetiva, então $\sigma_{\mathrm{H}}$ representa simplesmente a quantidade de $\mathrm{Cs}^{+}$dessorvido dos grupos de superfície variável a um dado $\mathrm{pH}$ e não o valor absoluto da densidade de carga protônica de superficie. Charlet \& Sposito (1987) observaram dissolução de 
matéria orgânica em oxissolo a $\mathrm{pH}$ elevado sendo portanto, recomendável trabalhar a $\mathrm{pH}$ 6,0 para evitar tal problema.

A medida de carga de superficie variável representa a quantidade do íon $\mathrm{Cs}^{+}$dessorvido pelo íon $\mathrm{Li}^{+}$dos sítios de superficie a $\mathrm{pH}$ 6,0, após lavagem com etanol e tratamento a $65^{\circ} \mathrm{C}$ dos solos saturados com césio $(\mathrm{CsCl})$. Embora o $\mathrm{Cs}^{+}$ possa formar complexos de esfera interna com grupos funcionais de superfície, a ligação não é forte o bastante para impedir a sua troca pelo $\mathrm{Li}^{+}$que é mais hidratado.

Os valores de $\sigma_{\mathrm{H}}$ sobre o valor médio entre as duas profundidades variaram de 35,8 a 61,0 $\mathrm{mmol}_{\mathrm{C}} \mathrm{kg}^{-1}$ na TE; 17,8 a 28,3 mmol $_{\mathrm{C}} \mathrm{kg}^{-1}$ no LRác-Rib; 15,8 a 32,0 mmol $_{\mathrm{C}} \mathrm{kg}^{-1}$ no LR ác-Gua; 10,1 a 14,1 $\mathrm{mmol}_{\mathrm{C}} \mathrm{kg}^{-1}$ no LUna ác-argare e de 18,5 a $33,7 \mathrm{mmol}_{\mathrm{C}} \mathrm{kg}^{-1}$ no LUna ác-mtarg. Observa-se que para todos os solos a $\sigma_{\mathrm{H}}$ na superficie é maior que na subsuperfície, possivelmente devido à maior quantidade da matéria orgânica presente. Verifica-se que a maior queda na $\sigma_{\mathrm{H}}$ no perfil foi para o solo TE $\left(26 \mathrm{mmol}_{\mathrm{C}} \mathrm{kg}^{-1}\right)$ e a menor foi para LUna ác-argare $\left(4 \mathrm{mmol}_{\mathrm{C}} \mathrm{kg}^{-1}\right)$.

Os valores medidos da carga variável $\left(\sigma_{\mathrm{H}}\right)$ (Tabela 6) são comparáveis aos valores obtidos nas determinações dessa carga em solos brasileiros feitas por Anderson \& Sposito (1991) (20,3 mmol $_{\mathrm{C}} \mathrm{kg}^{-1}$ solo), Chorover (1993) (31 a 60 mmol $_{\mathrm{C}} \mathrm{kg}^{-1}$ solo), Peixoto (1995) (39 a $73 \mathrm{mmol}_{\mathrm{C}} \mathrm{kg}^{-1}$ solo) e Fontes \& Sposito (1995) (9 a $32 \mathrm{mmol}_{\mathrm{C}} \mathrm{kg}^{-1}$ solo).

Os valores da carga permanente $\left(\sigma_{0}\right)$ medidos pela quantidade do íon $\mathrm{Cs}^{+}$ dessorvido pelo íon $\mathrm{NH}_{4}^{+}\left(\mathrm{AcONH}_{4}\right)$ após a reação de troca $\mathrm{Li}^{+} \rightarrow \mathrm{Cs}^{+}$, são apresentados na Tabela 6 . Os valores de carga permanente sobre o valor médio entre as profundidades variaram de 51,1 a $41,1 \mathrm{mmol}_{\mathrm{c}} \mathrm{kg}^{-1} \mathrm{na} T E$; 11,7 a $9,1 \mathrm{mmol}_{\mathrm{c}} \mathrm{kg}^{-1}$ no LRác- Rib; 10,4 a $5,9 \mathrm{mmol}_{\mathrm{c}} \mathrm{kg}^{-1}$ no LR ác-Gua; 
Tabela 6. Cargas efetivas de superfície medidas pela adsorção de Cs e coeficientes de seletividade condicionais ( ${ }^{\mathrm{C}} \mathrm{Kex}$ ) para troca de $\mathrm{Li}^{+} \rightarrow \mathrm{Cs}^{+}$e frações molares $(x \mathrm{Cs})$ de $\mathrm{Cs}^{+}$nas amostras originais dos solos estudados.

\begin{tabular}{|c|c|c|c|c|c|c|}
\hline Solo & Prof $(\mathrm{cm})$ & $-\sigma_{H}^{\prime}$ & $-\sigma_{0}{ }^{1}$ & $-\sigma_{\text {TOTAL }}{ }^{1}$ & $\left({ }^{C}\right.$ Kex $)$ & $(x \mathrm{Cs})$ \\
\hline \multirow[t]{3}{*}{$\mathrm{TE}$} & $0-20$ & $61,8\left(0,4^{2} ; 55^{3}\right)$ & $51,1(0,7 ; 45)$ & $113,3(0,3)$ & $10,6\left(0,3^{1}\right)$ & $0,45(0,00)$ \\
\hline & $75-95$ & $35,8 \quad(0,6 ; 47)$ & $41,1(0,1 ; 53)$ & $77,0(0,6)$ & $26,4(0,9)$ & $0,53(0,00)$ \\
\hline & média & $48,8(18,4 ; 51)$ & $46,9(7,3 ; 49)$ & $95,1 \quad(25,7)$ & $18,5(11,1)$ & $0,49(0,05)$ \\
\hline \multirow[t]{3}{*}{ LRác-Rib } & $0-20$ & $28,3(0,9 ; 71)$ & $11,7(0,2 ; 29)$ & $40,0(0,8)$ & $12,0(0,9)$ & $0,29(0,01)$ \\
\hline & $100-140$ & $17,8(0,7 ; 66)$ & $9,1(0,3 ; 34)$ & $27,0(0,6)$ & $23,9(2,5)$ & $0,33(0,01)$ \\
\hline & média & $23,1(7,4 ; 69)$ & $10,4(1,9 ; 31)$ & $33,5(9,3)$ & $18,0(8,4)$ & $0,31(0,03)$ \\
\hline \multirow[t]{3}{*}{ LRác-Guaí } & $0-20$ & $32,0(0,5 ; 76)$ & $10,4(0,2 ; 24)$ & $42,4(0,4)$ & $8,3(0,4)$ & $0,24(0,00)$ \\
\hline & $100-150$ & $15,8(0,1 ; 73)$ & $5,9(0,0 ; 27)$ & $21,6(0,1)$ & $19,7(0,2)$ & $0,27(0,00)$ \\
\hline & média & $23,9(11,5 ; 75)$ & $8,1(0,1 ; 25)$ & $32,0(14,7)$ & $14,0(8,1)$ & $0,26(0,02)$ \\
\hline \multirow[t]{3}{*}{ LUna ácargare } & $0-20$ & $14,1(0,3 ; 71)$ & $5,8(0,2 ; 29)$ & $19,9(0,2)$ & $24,5(1.9)$ & $0,29(0,01)$ \\
\hline & $30-70$ & $10,1(0,6 ; 73)$ & $3,7(0,2 ; 27)$ & $13,8(0,9)$ & $30,8(1.7)$ & $0,26(0,00)$ \\
\hline & média & $12,1(2,8 ; 75)$ & $4,8(0,0 ; 28)$ & $16,9(4,3)$ & $27,6(4.5)$ & $0,28(0,02)$ \\
\hline \multirow[t]{3}{*}{ LUna-ácmtarg } & $0-20$ & $33,7(0,3 ; 77)$ & $10,6(0,3 ; 23)$ & $44,3(0,4)$ & $7,6(0,3)$ & $0,24(0,00)$ \\
\hline & $60-90$ & $18,5(0,3 ; 69)$ & $8,36(0,1 ; 31)$ & $27,0(0,3)$ & $20,4(0,8)$ & $0,31(0,00)$ \\
\hline & média 1 & $26,1(10,0 ; 73)$ & $9,46(0,2 ; 27)$ & $35,6(12,3)$ & $14,0(9,1)$ & $0.27(0,05)$ \\
\hline
\end{tabular}

1:- $\sigma_{\mathrm{H}}=$ adsorção do ion $\mathrm{Cs}^{+}$para os sítios de carga variáveis; $-\sigma_{0}=$ adsorção do ion $\mathrm{Cs}^{+}$para sítios de carga permanente $\mathrm{e}-\sigma_{\mathrm{TOTAL}}=$ adsorção do ion $\mathrm{Cs}^{+}$para sítios de carga total.

${ }^{2}$ : valores entre parênteses representam desvio padrão e ${ }^{3}$ participação em percentagem de. $-\sigma_{H} e-\sigma_{0}$ na carga total; 
5,8 a 3,7 $\mathrm{mmol}_{\mathrm{c}} \mathrm{kg}^{-1}$ no LUna ác argare e 10,6 a 8,3 $\mathrm{mmol}_{\mathrm{C}} \mathrm{kg}^{-1}$ no LUna ácmtarg. Estes valores estão em concordância com os obtidos em avaliações feitas em oxissolos brasileiros por Chorover (1993) (8-21 $\left.\mathrm{mmol}_{\mathbf{c}} \mathrm{kg}^{-1}\right)$, Peixoto (1995) (7-38 $\mathrm{mmol}_{\mathrm{c}} \mathrm{kg}^{-1}$ ) e Fontes \& Sposito (1995) (8-37 $\left.\mathrm{mmol}_{\mathrm{c}} \mathrm{kg}^{-1}\right)$, mas não com os valores de Anderson \& Sposito (1991) $\left(0,03 \mathrm{mmol}_{\mathbf{c}} \mathrm{kg}^{-1}\right)$. Ao comparar a carga permanente da TE com os demais solos, verifica-se que este solo apresenta carga permanente quase cinco vezes superior ao LRác-Gua, por exemplo. Esta grande diferença pode ser devido ao fato de o LR ác-Gua conter de quatro a cinco vezes mais gibbsita que a $T E$, e que este solo apresenta minerais $2: 1+$ amorfos e o dobro da caulinita do que aquele (Tabela 5).

Ao confrontar as cargas permanentes dos latossolos roxos observam-se que a carga diminuiu à medida que o índice de intemperização diminuiu ou seja, o LR ác-Rib com ki maior que o ki do LR ác-Gua apresentaram no horizonte B uma carga de 9,1 e 5,9 $\mathrm{mmol}_{\mathbf{c}} \mathrm{kg}^{-1}$, respectivamente. Isto também pode ser parcialmente explicado, provavelmente, pela maior quantidade de minerais $2: 1+$ amorfos nas frações silte e areia, que constituem fontes potenciais dessas cargas.

Por outro lado, nos latossolos variação Una, o índice ki dos solos são quase iguais, não apresentando relação direta com o decréscimo da $\sigma_{0} \mathrm{em}$ profundidade. $O$ fato pode ser explicado, provavelmente, pelo maior teor da fração silte (Tabela 5), do LUna ác-mtarg em comparação ao LUna ác-argare que na análise mineralógica, esta fração continha presença de minerais 2:1.

Mesmo para o solo LUna ác-argare, o método de adsorção de Cs detectou uma quantidade média no perfil de $4,8 \mathrm{mmol}_{\mathrm{C}} \mathrm{kg}^{-1}$ de solo da carga permanente, sendo que esta quantidade de carga medida deve-se à carga originada de minerais 2:1 que, provavelmente, se encontram como impurezas na superficie da caulinita uma vez que a contribuição para a carga permanente da substituição isomórfica nos silicatos $1: 1$, como a caulinita, é tipicamente menor que $20 \mathrm{mmol}_{\mathrm{C}} \mathrm{kg}^{-1}$ Sposito (1989). 
Estes resultados são consistentes com as análises mineralógicas, pois as fontes de carga permanentes detectadas pelo DRX nas frações argilas são minerais micáceos colapsados, em que somente a superficie externa e os sítios das arestas entrecamadas (Bolt et al, 1963) estariam acessíveis ao íon césio. Além disso, ao examinar a fração areia muito fina dos solos em microscópio óptico observou-se que óxidos de ferro recobriam as superfícies dos minerais micáceos e não micáceos, recobrimentos estes que reduzem o número de sítios acessíveis à adsorção catiônica da superficie siloxana dos argilominerais 2:1 (Roth et al., 1969; Ghabru et al, 1989).

A carga total comportou-se de forma idêntica às cargas variáveis e permanentes, isto é, decresceu em profundidade. Os valores de $\sigma_{\text {TOTAL }}$ sobre os valores médios variaram de 113,3 a $77,0 \mathrm{mmol}_{\mathbf{c}} \mathrm{kg}^{-1}$ no solo TE, de 40 a $27 \mathrm{mmol}_{\mathrm{c}} \mathrm{kg}^{-1}$ no LR ác-Rib, de 42,4 a $21,6 \mathrm{mmol}_{\mathrm{c}} \mathrm{kg}^{-1}$ no LR ácGua, 19,9 a 13,8 $\mathrm{mmol}_{\mathrm{c}} \mathrm{kg}^{-1}$ no LUna ác-argare e de 44,3 a 22,0 mmol $_{\mathrm{c}} \mathrm{kg}^{-1}$ no LUna ác-mtarg. Pode-se observar que os valores apresentados da $\sigma_{\text {TOTAL }}$ $\left(113,3\right.$ e $\left.77,0 \mathrm{mmol}_{\mathrm{c}} \mathrm{kg}^{-1}\right)$ da TE foram maiores nas duas profundidades em relação ao LUna ác-argare, cuja carga total foi menor em relação aos outros latossolos ácricos, dentre outros fatores por causa do maior teor de carbono na superficie que na subsuperficie (Tabela 3) que, proporcionalmente, contribuíram para a referida carga. Estes resultados demonstram o importante papel que a matéria orgânica exerce sobre a capacidade de troca de íons, confirmando as observações de Raij \& Peech (1972).

Uma das possíveis causas da redução da CTC em profundidade se deve à presença de hidróxido de alumínio nas entrecamadas da vermiculita, o qual bloqueia os sítios de troca e/ou neutraliza a carga negativa nas entrecamadas pela adsorção de espécies de alumínio exercerndo um efeito bastante drástico nas propriedades fisico-químicas (Bamhisel \& Bertsch, 1989). Esses dois fatos, 
podem provavelmente ser confirmados segundo considerações de Oades (1989) que afirma que, se os valores obtidos do PESN estiverem na faixa de 2 a 4 e, portanto menor que o $\mathrm{pH}$ do solo são indícios da contribuição da matéria orgânica e de minerais 2:1 para a CTC.

Pelos resultados apresentados na Tabela 6, verifica-se que as cargas variáveis apresentam significativa contribuição para as cargas totais, podendo-se observar que para os valores médios entre as profundidades, as cargas variável e permanente compreendem respectivamente 51 e 49\% na TE, 69 e $31 \%$ no LR ácRib , 75 e 25\% no LR ác-Gua, 72 e 28\% no LUna ác argare e 73 e 27\% no LUna ác-mtarg. Pode ser observado que mais da metade das cargas negativas tem sua origem em superfícies de carga variável. De forma decrescente, verifica-se que a ordem de contribuição dos solos para a carga variável é: LR ác-Gua > LUna ácmtarg > LUna ác-argare > LR ác-Rib > TE, enquanto que a contribuição para cargas permanentes também em ordem decrescente é a seguinte: TE > LR ácRib> LR ác-Gua> L Una ác-mtarg > L Una ác-argare.

Apesar do método de adsorção de césio proposto por Anderson \& Sposito (1991) modificado por Chorover \& Sposito (1993), ser recomendado para solos com elevado teor de minerais $2: 1$, o mesmo mostrou-se capaz em detectar quantidades significativas de carga permanente acessível em solos oxídicos.

\subsection{Coeficientes de seletividade condicionais $\left({ }^{C} \mathrm{~K}_{\mathrm{EX}}\right)$ para a troca $\mathrm{Li}^{+} \rightarrow \mathrm{Cs}^{+}$ em TE e em solos ácricos originais.}

O coeficiente de seletividade ( ${ }^{c} \mathrm{~K}_{\mathrm{EX}}$ ) representa a afinidade dos solos pelo ín césio. Os valores desses coeficientes para a troca $\mathrm{Li}^{+} \rightarrow \mathrm{Cs}^{+}$a pH 6,0 e numa força iônica de $0,01 \mathrm{~mol} \mathrm{~kg}^{-1}$ para os solos estudados estão relacionados à mistura 
específica dos grupos funcionais de carga de superficie permanente e variável em cada solo (Tabela 6) e foram obtidos dos resultados das cargas elétricas permanente estrutural, da total e das concentrações molares de césio e lítio nos extratos da determinação das cargas. Os valores de $\left({ }^{\mathrm{c}} \mathrm{K}_{\mathrm{EX}}\right)$ variaram de 10,61 a 26,39 para TE; 12,05 a 23,90 para LRác-Rib; 8,28 a 19,72 para LRác-Gua; 24,48 a 30,84 para LUna ác-argare e 7,58 a 20,44 para LUna ác- mtarg respectivamente, para a superficie e subsuperficie. Estes coeficientes estão em parte, compatíveis com os coeficientes obtidos por Bruggenwert \& Kamphorst (1979), para reações de troca $\mathrm{Li}^{+} \rightarrow \mathrm{Cs}^{+}$em minerais de argila 2:1 e em alguns outros componentes do solo.

Esse um aumento no $\left({ }^{\mathrm{c}} \mathrm{K}_{\mathrm{EX}}\right)$ em profundidade em relação à superficie para todos os solos (Tabela 6), poderia estar relacionado ao decréscimo da matéria orgânica correspondente (Tabela 3) conforme também verificado por Peixoto (1995). Este fato, parece denotar uma menor afinidade da matéria orgânica em relação à fração mineral pelo íon césio. Contudo, o $\mathrm{Cs}^{+}$é ainda preferido pela matéria orgânica nas duas profundidades devido ao seu menor raio iônico de hidratação (Stevenson, 1994).

Outra provável explicação para o baixo coeficiente de seletividade na superficie, que segundo Maguirre et al., (1992), se deve aos ácidos húmicos ligados às superfícies dos argilominerais que potencialmente bloqueiam os sítios de troca impedindo a sorção de césio. Aliado ao efeito de bloqueamento, o próprio ácido húmico diminui a sorção por causa dos seus sítios húmicos poliméricos sítios de baixa energia de troca com nenhuma especificidade pelo césio.

Nas amostras de solos da subsuperficie a influência da fase mineral parece dominar a afinidade pelo íon césio e poderia ser explicada pela presença de pequenos picos de minerais 2:1 apesar do horizonte superficial também apresentar esses minerais. Este fato pode ser explicado em parte, pela sorção 
altamente seletiva de $\mathrm{Cs}^{+}$em concentrações traços de muitos minerais de argila 2:1 e ocorre nos espaços entrecamadas próximos das arestas quebradas (Sawhney, 1972; Comans et al., 1991). A baixa energia de hidratação do íon césio aumenta a tendência desses minerais perderem as águas de hidratação e formar ligações polares com átomos de oxigênio estrutural da cavidade siloxana. A adsorção de íns desidratados induz as entrecamadas a colapsarem ocorrendo, então, a retenção seletiva de íons (Chorover, 1993).

Observa-se que o LUna ác-argare apresentou valores de coeficiente de seletividade maiores tanto na superficie quanto na subsuperficie em relação aos demais solos, o que é atribuído, possivelmente, à presença de mineral 2:1 VHE cloritizada (Tabela 6). Os menores valores desses coeficientes para o LRác- Gua e LUna ac-mtarg comparados aos valores de TE, LRác-Rib e LUna ác-argare poderiam ser parcialmente explicados graças à neutralização dos seus sítios nas entrecamadas, carregadas negativamente, por grupos hidroxi-Al, em quantidades substancial ou mesmo pela diferença quantitativa em espécies (Peixoto, 1995).

Essas espécies de hidróxido de alumínio nas entrecamadas atuam como uma barreira, inibindo o colapsamento da camada, prevenindo consequentemente a fixação de íons com baixa energia de hidratação, como por exemplo, $\mathrm{K}^{+}, \mathrm{NH}_{4}^{+}$, $\mathrm{Rb}^{+}$e $\mathrm{Cs}^{+}$, diminuindo portanto, suas seletividades (Rich \& Black, 1964, Sawhney, 1972; Eberl, 1980, Bamhisel \& Bertsch, 1989, Comans, et al., 1993).

A menor energia de hidratação de $\mathrm{Cs}$ em relação ao $\mathrm{Li}$, favorece sua difusão nos espaços entrecamadas e a subseqüente formação de complexos de esfera interna com a cavidade ditrigonal siloxana. Este comportamento tem sido relacionado com a configuração eletrônica do césio e explicado semiquantitativamente pela sua eletronegatividade absoluta e variação da polarizabilidade baseado no princípio HSAB (Sawhney, 1965,1972; Eberl, 1980; Anderson, 1989; Xu \& Harsh, 1990b; Chorover , 1993 e Peixoto, 1995). 
Peixoto (1995) obteve valores de $\left({ }^{\mathrm{C}} \mathrm{K}_{\mathrm{EX}}\right)$ variando de 3,8 a 22,1 para um solo Humic Rhodic, caulinítico (RH); 8,9 a 21,5 para um solo Typic Hapludox, ferruginoso/ sesquioxídico (TH) e 7,4 a 15,7 para um solo Humic Rhodic Hapludox, sesquioxídico/ gibbsítico, enquanto que Chorover (1993), obteve valores de $\left({ }^{C} \mathrm{~K}_{\mathrm{EX}}\right)$ variando de 4,3 a 8,1 para diferentes oxissolos e 22,3 para um mineral ilita (após três lavagens com $\mathrm{LiCl}$ ) indicando uma progressiva remoção de césio dos sítios de energia de ligação.

Entre os latossolos ácricos, a maior afinidade ao íon césio foi apresentada pelo LUna ác-argare $(27,66)$, e os com menor afinidade foram o LR ác-Gua $(14,0)$ e o LUna ác-mtarg $(14,01)$ observando-se afinidade intermediária foi observado para o LR ác- Rib.

Comparando-se os coeficientes de seletividade condicionais entre os latossolos roxos ácricos e entre os latossolos variação Una, verifica-se que o LR ác-Rib e LUna ác-argare foram os dois solos mais seletivos ao ín césio nas respectivas classes. A diferença na seletividade para a VHE cloritizada desses solos possivelmente possa ser atribuída à quantidade de carga negativa gerada na substituição isomórfica de um argilomineral 2:1 em relação a outro, onde essa diferença na substituição faz com que a cavidade siloxana ditrigonal da VHE cloritizada de um solo seja uma base de Lewis mais polarizável que a VHE cloritizada de outro solo. Com base no princípio HSAB, pode-se concluir que, a polarizabilidade do ácido de Lewis do cátion complexado aumentou e, consequentemente as VHEs cloritizadas do LR ác-Gua e LUna ác-argare formariam complexos de esfera interna mais estáveis que as VHE cloritizadas dos LR ác-Rib e LUna ác-mtarg de acordo com as considerações de Sposito, (1984).

Para que um adsorvente tenha um comportamento ideal, os coeficientes de atividade de superfície para uma troca binária de mesma carga deve apresentar valor constante de uma unidade e o coeficiente de seletividade também deve apresentar um valor constante para todas composições de superficie (Gast,1972). 
No entanto, este comportamento não foi observado no presente estudo e nem tem sido observado nas reações de troca monovalente-monovalente em todos os cátions do grupo IA (Sawhney, 1972; Gast, 1972; Comans, 1991; Chorover, 1993; McBride, 1994).

\subsection{Comportamento das cargas elétricas após remoção da matéria orgânica e} dos óxidos de ferro.

4.5.1 Cargas elétricas após remoção da matéria orgânica.

Os valores calculados das cargas variáveis, permanentes e totais para os solos estudados após sofrerem tratamento para remoção da matéria orgânica, encontram-se na Tabela 7.

Os valores de carga variável sobre o valor médio entre as duas profundidades variaram de 48,9 a $49,1 \mathrm{mmol}_{\mathrm{c}} \mathrm{kg}^{-1}$ na TE; 23,7 a $25,8 \mathrm{mmol}_{\mathrm{c}} \mathrm{kg}^{-1}$ no LR ác-Rib; 22,5 a 29,5 $\mathrm{mmol}_{\mathrm{c}} \mathrm{kg}^{-1}$ no LRác. Gua; 14,1 a $14,5 \mathrm{mmol}_{\mathrm{c}} \mathrm{kg}^{-1}$ no LUna argare e 24,0 a $26,7 \mathrm{mmol}_{\mathrm{c}} \mathrm{kg}^{-1}$ no LUna mtarg. Verifica-se que houve pequeno decréscimo de $0,2 \mathrm{mmol}_{\mathrm{c}} \mathrm{kg}^{-1}$ na carga variável negativa em profundidade para TE; $2,1 \mathrm{mmol}_{\mathrm{c}} \mathrm{kg}^{-1}$ para LR ác-Rib; $2,7 \mathrm{mmol}_{\mathbf{c}} \mathrm{kg}^{-1}$ para LUna ác-mtarg e a maior queda foi verificada para o LRác-Gua de 7,0 $\mathrm{mmol}_{\mathrm{C}} \mathrm{kg}^{-1}$ a exceção ficou com o LUna ác-argare que comportou-se de modo inverso, com um pequeno acréscimo de $0,4 \mathrm{mmol}_{\mathbf{c}} \mathrm{kg}^{-1}$.

Com a remoção da matéria orgânica, verifica-se que houve decréscimo da carga variável negativa na superficie de $12,7,2,5,2,5,7,0$ mmol $_{\mathbf{c}} \mathrm{kg}^{-1}$ para a TE, o LR ác-Rib , o LR ác-Gua e o LUna ác-mtarg, respectivamente, enquanto o LUna ác-argare teve sua carga variável mantida. Ao passo que, na subsuperfície ocorreu acréscimo para todos os solos de 13,1, 5,9, 6,7, 5,0 e 4,4 mmol $_{\mathrm{c}} \mathrm{kg}^{-1}$. 
Portanto, os decréscimos da carga variável na superficie parecem estar relacionados à grande contribuição da fração orgânica, ao passo que na subsuperficie os acréscimos ocorreram, provavelmente, com a exposição dos sítios da carga variável da fração inorgânica. Caso inverso ocorreu com o LUna ác-argare, nessa profundidade, verificando-se igual quantidade de carga variável na condição da matéria orgânica removida, reflexo de que a fração orgânica não teve grande contribuição nessa situação ou, provavelmente por ser um solo que contém 35\% de argila (Tabela 5), isto indica que solos arenosos a arenoargilosos não propiciam um acúmulo significativo de matéria orgânica $e$, consequentemente não se verifica aumento na sua CTC (Sposito, 1989a). Por outro lado, na subsuperficie a matéria orgânica influiu bastante no comportamento dessa carga.

As cargas variáveis negativas, com a remoção da matéria orgânica, obedeceu a seguinte ordem: na superficie - TE > LR ác-Gua > LU ác-mtarg > LR ác-Rib > LUna ác-argare; na subsuperficie - TE > LUna ác-mtarg > LR ácRibeirão > LR ác-Gua > LUna ác-argare.

A variação dos valores da carga permanente negativa dos solos onde a matéria orgânica foi removida sobre o total do perfil foi 49,0 a 49,3 para a TE; 10,8 a 15,7 mmol $_{\mathrm{c}} \mathrm{kg}^{-1}$ para LR ác-Rib.; 10,5 a 13,8 $\mathrm{mmol}_{\mathrm{c}} \mathrm{kg}^{-1}$ solo para o LR ác.-Gua; 5.1 a $6,3 \mathrm{mmol}_{\mathrm{c}} \mathrm{kg}^{-1}$ para LUna ác-argare; e 14,4 a 16,4 $\mathrm{mmol}_{\mathrm{c}} \mathrm{kg}^{-1}$ para LUna mtargare. Nota-se um decréscimo da carga permanente em profundidade para quase todos os solos, o mesmo não ocorrendo com o LUna ác-argare que comportou-se de modo inverso.

Ao comparar as cargas permanentes dos solos originais com os solos sem matéria orgânica (Figura 16) constatou-se que houve redução da carga permanente na superficie e acréscimo na subsuperficie para a TE, e o LUna ácargare, cujos valores foram de 1,8 e 7,9 $\mathrm{mmol}_{\mathrm{C}} \mathrm{kg}^{-1}$ solo para o primeiro solo e de 0,7 e 2,6 $\mathrm{mmol}_{\mathrm{C}} \mathrm{kg}^{-1}$ para o segundo. A redução dessa carga na superficie se deve 
Tabela 7. Cargas efetivas de superficie medidas pela adsorção de Cs em amostras deluma Terra Roxa Estruturada e dos solos ácricos com matéria orgânica removida.

\begin{tabular}{|c|c|c|c|c|}
\hline Solo & Prof $(\mathrm{cm})$ & $-\sigma_{H}^{1}$ & $-\sigma_{0}^{1}$ & $-\sigma_{\text {total }}{ }^{1}$ \\
\hline \multirow[t]{3}{*}{ TE } & $0-20$ & $49,1(0,1 ; 50)^{2}$ & $49,3(1,0 ; 50)$ & $98,6(1,0)$ \\
\hline & $75-95$ & $48,9(3,3 ; 50)$ & $49,0(1,6 ; 50)$ & $97,9(3,6)$ \\
\hline & média & $49,1(0,2 ; 50)$ & $49,2(0,2 ; 50)$ & $98,2(0,4)$ \\
\hline \multirow[t]{3}{*}{ LRác-Rib } & $0-20$ & $25,8(0,0 ; 62)$ & $15,7(0,6 ; 38)$ & $41,5(0,6)$ \\
\hline & $100-140$ & $23,7(2,1 ; 69)$ & $10,8(0,4 ; 31)$ & $34,5(1,9)$ \\
\hline & média & $24,7(1,5 ; 65)$ & $13,2(3,5 ; 35)$ & $38,0(4,9)$ \\
\hline \multirow[t]{2}{*}{ LRác-Gua } & $0-20$ & $29,5(0,5 ; 68)$ & $13,8(0,2 ; 32)$ & $43,3(0,5)$ \\
\hline & $100-150$ & $22,5(0.1 ; 68)$ & $10,5(0,3 ; 32)$ & $33,0(0,4)$ \\
\hline - & média & $26,0(4,9 ; 68)$ & $12,2(3,0 ; 32)$ & $38,2(7,2)$ \\
\hline \multirow[t]{3}{*}{ LUna ác- argare } & $0-20$ & $14,1(0,1 ; 73)$ & $5,1(0,6 ; 27)$ & $19,3(0,8)$ \\
\hline & $30-70$ & $14,5(1,9 ; 70)$ & $6,3(1,1 ; 30)$ & $20,8(3,0)$ \\
\hline & média & $14,3(0,2 ; 72)$ & $5,7(0,8 ; 28)$ & $20,0(1,0)$ \\
\hline \multirow[t]{3}{*}{ LUna ác-mtarg } & $0-20$ & $26,7(0,7 ; 62)$ & $16,4(1,3 ; 28)$ & $43,1 \quad(1,2)$ \\
\hline & $60-90$ & $24,0(0,1 ; 62)$ & $14,4(0,1 ; 28)$ & $38,4(0,2)$ \\
\hline & média & $25,4(1,9 ; 62)$ & $15,4(1,4 ; 28)$ & $40,8(3,3)$ \\
\hline \multicolumn{5}{|c|}{$\begin{array}{l}2 \text { : valores entre parênteses representam desvio padrão e participação em percentagem de },-\sigma_{H} \text { e }-\sigma_{0} \text { na carga } \\
\text { total. } \\
3 \text {.média entre as duas profundidades. }\end{array}$} \\
\hline
\end{tabular}


à complexação do íon césio com a fração orgânica que superestimou as cargas elétricas para TE e LUna ác-argare em condições naturais. Na subsuperficie a fração mineral apresentou maior contribuição e, com a remoção da fração orgânica, que possivelmente se encontrava recobrindo a fração inorgânica, possibilitou uma exposição maior dos sítios de carga permanente sítios de carga permanente levando a uma adsorção maior o íon césio e, consequentemente, a um acréscimo desse tipo de carga para os referidos solos.

Cabe ressaltar que a diferença dos valores de $\sigma_{0}$ na camada superficial para, praticamente, a mesma quantidade de carbono total, caso da TE $\left(26 \mathrm{~g} \mathrm{~kg}^{-1}\right)$, do LR ác-Gua $\left(25 \mathrm{~g} \mathrm{~kg}^{-1}\right)$ e do LUna ác-mtarg $\left(24 \mathrm{~g} \mathrm{~kg}^{-1}\right)$, pode ser causada, segundo Peixoto (1995), pelas diferenças qualitativas dos grupos funcionais da matéria orgânica.

Para os solos LR ác.-Rib, LR ác.-Gua e LUna ác-mtarg observou-se acréscimo na carga permanente nas duas profundidades com a remoção da matéria orgânica, o que indica que a fração orgânica provavelmente não constituiu uma barreira aos sítios de troca com carga permanente, resultando então num pequeno aumento. Esse aumento para os respectivos solos e profundidades foram 4,0 e 1,7,3,4 e 4,6 e de 5,8 e 6,0 mmol $_{\mathrm{c}} \mathrm{kg}^{-1}$ de solo.

A maior redução da carga permanente negativa na superfície com a remoção da matéria orgânica foi verificada para a TE $\left(1,8\right.$ mmol $\left._{\mathbf{c}} \mathrm{kg}^{-1}\right)$ e o maior aumento na subsuperficie foi observada para a TE (7,9 $\mathrm{mmol}_{\mathrm{c}} \mathrm{kg}^{-1}$ solo), LUna $\operatorname{mtarg}\left(6,0 \mathrm{mmol}_{\mathrm{c}} \mathrm{kg}^{-1}\right.$ solo) e LR ác.-Gua $\left(4,6 \mathrm{mmol}_{\mathrm{c}} \mathrm{kg}^{-1}\right)$.

A carga total comportou-se de forma similar à carga permanente negativa verificando-se que a TE e o LUna ác-argare apresentaram uma redução na superficie e acréscimo na subsuperficie, enquanto que os demais solos tiveram suas cargas acrescidas nas duas profundidades. 
A remoção da matéria orgânica revelou redução na carga total em superficie e aumento na subsuperficie de 14,3 e 21,0 mmol $\mathrm{kg}^{-1}$ para TE, de 0,6 e $3,1 \mathrm{mmol}_{\mathrm{c}} \mathrm{kg}^{-1}$ para o LUna ác-argare e de 1,2 e 11,5 $\mathrm{mmol}_{\mathrm{c}} \mathrm{kg}^{-1}$ para LUna ácmtarg. Para os demais solos verificou-se aumento nas cargas totais nas duas profundidades estudadas onde foram obtidos os seguintes valores: 1,5 e 7,6 $\mathrm{mmol}_{\mathfrak{c}}$ $\mathrm{kg}^{-1}$ de solo para o LR.ác.-Rib, 0,9 e 11,6 $\mathrm{mmol}_{\mathrm{c}} \mathrm{kg}^{-1}$ de solo para o LR ác- Gua

O comportamento das cargas totais desses solos pode ser explicado com base no fato de uma parte considerável da fração orgânica encontrar-se combinada com a fração inorgânica e essa interação, segundo Oades, (1989), também modifica a CTC de cada fração resultando numa menor quantidade de carga negativa de superfície do complexo organomineral em relação à soma das cargas dos dois componentes separadamente. Daí, o argumento de Stevenson (1994), de que a CTC da matéria orgânica e do argilomineral num solo natural não podem ser considerados aditivos, pois alguns sítios são perdidos pelas interações entre os dois e muitos sítios orgânicos podem estar formando complexos com cátions polivalentes como por exemplo $\mathrm{Ca}^{2+}, \mathrm{Al}^{3+}, \mathrm{Fe}^{3+}, \mathrm{Mn}^{2+}$ etc.

Torna-se evidente que a fração orgânica na camada superficial contribuiu com grande parte de sua carga para a troca catiônica, ao passo que na subsuperficie os sítios orgânicos que formavam complexos com cátions polivalentes, ao serem destruídos, promoveram maior exposição de sítios de troca da fração inorgânica que se encontravam bloqueados, resultando num acréscimo das cargas totais.

Estes resultados estão em concordância com os resultados obtidos por Sumner (1964), Follet (1965), Raij (1969), Greenland (1975), Krishnamoorty et al., (1976); Shuman (1976); Curtin \& Smillie (1979, Peixoto (1995), Itami (1996). 

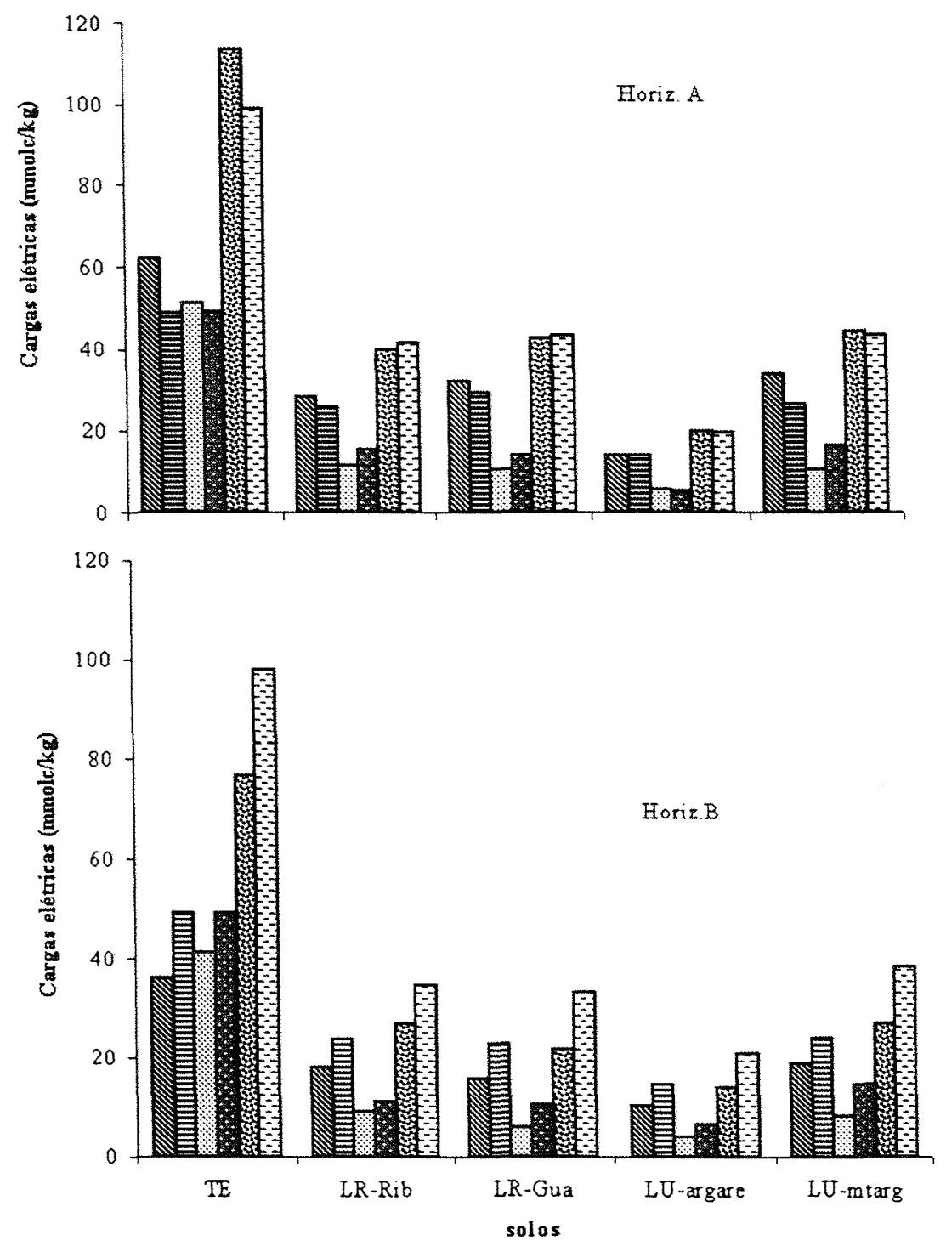

Figura 16 Características das cargas elétricas dos horizontes superficial (A) e subsuperficial $(\mathrm{B})$ dos solos originais $\left(\mathrm{T}_{1}\right)$ e dos solos com matéria orgânica removida $\left(\mathrm{T}_{2}\right)$. 
Mesmo com a remoção da fração orgânica, os resultados da Tabela 7 demonstraram que as cargas variáveis e permanentes foram responsáveis respectivamente por $50 \%$ na TE para cada profundidade, $65 \%$ e $35 \%$ no LR ácRib, $68 \%$ e $32 \%$ no LR ác-Gua, $72 \%$ e $28 \%$ no LUna ác-argare e $62 \%$ e $38 \%$ no LUna ác-mtarg. Portanto, a relação entre a carga permanente estrutural e a carga total no solo depende da quantidade e também da qualidade da matéria orgânica presente. Como exemplo, cita-se o LUna ác-argare com teor de carbono total de $16 \%$ e $6 \%$ nas respectivas profundidades para uma contribuição da carga estrutural da fração mineral com $2,6 \%$ da carga negativa total na camada superficial enquanto que na subsuperficie foi de 30\% o que em parte confirma, a relação entre as cargas permanente e total quanto à quantidade e qualidade da matéria orgânica.

4.5.2 Cargas elétricas após remoção do óxido de ferro amorfo

Os valores calculados das cargas variáveis, permanentes e totais para os solos após serem submetidos ao tratamento de remoção do óxido de ferro por meio da solução Tam, encontram-se na Tabela 8. Neste tratamento as amostras dos solos contêm matéria orgânica e óxido de ferro livre.

Os valores da carga variável variaram de 77,8 a 59,4 mmol $_{\mathrm{c}} \mathrm{kg}^{-1}$ na TE;

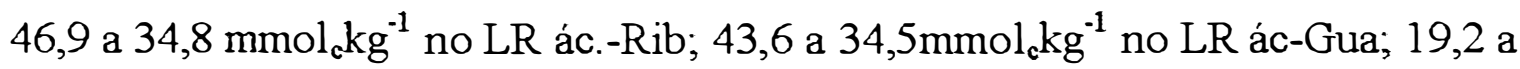
$13,6 \mathrm{mmol}_{\mathrm{c}} \mathrm{kg}^{-1}$ no LUna. ác-argare e 38,9 a 36,0 mmol $\mathrm{kg}^{-1}$ no LUna. ác-mtarg. Para todos os solos verifica-se que houve um decréscimo da carga variável negativa em profundidade.

Ao comparar o comportamento das cargas variáveis dos solos originais com aqueles onde óxido de ferro amorfo foi eliminado (Tabelas 6 e 8; Figura 17) observou-se acréscimo das referidas cargas nas duas profundidades para todos 
Tabela 8 Cargas efetivas de superficie medidas pela adsorção de Cs em amostras de uma Terra Roxa Estruturada e em solos ácricos com ferro amorfo removido.

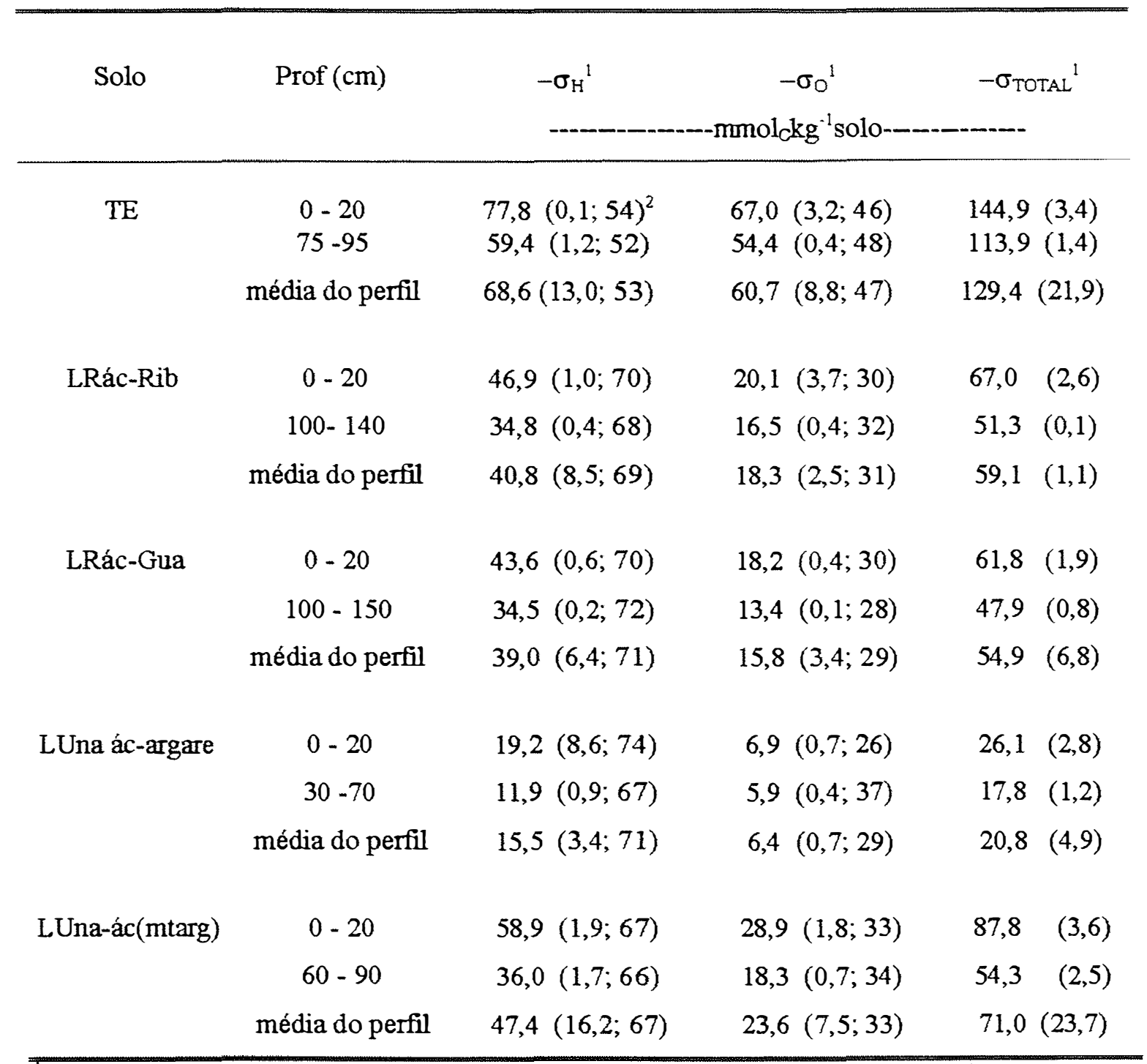

:- $\sigma_{\mathrm{H}}=$ adsorção do íon $\mathrm{Cs}^{+}$para os sitios de carga variáveis; $-\sigma_{0}=$ adsorção do íon $\mathrm{Cs}^{+}$para sítios de carga permanente $\mathrm{e}-\sigma_{\text {TOTAL }}=$ adsorção do íon $\mathrm{Cs}^{+}$para sítios de carga total. ${ }^{2}$ : valores entre parênteses representam desvio padrão e participação em percentagen de. $-\sigma_{H}$ e $-\sigma_{0}$ na carga total. 
os solos tratados. Esses acréscimos foram de 16,0 e 23,6 $\mathrm{mmol}_{\mathrm{c}} \mathrm{kg}^{-1}$ para o TE; 18,6 e $17,0 \mathrm{mmol}_{\mathrm{c}} \mathrm{kg}^{-1}$ para o LR.ác-Rib, 11,6 e 18,7 $\mathrm{mmol}_{\mathrm{c}} \mathrm{kg}^{-1}$ para o LR.ácGua; 5,1 e 3,5 $\mathrm{mmol}_{\mathfrak{c}} \mathrm{kg}^{-1}$ para o LUna.ác-argare e de 25,2 e 17,5 $\mathrm{mmol}_{\mathfrak{c}} \mathrm{kg}^{-1}$ para o LUna.ác-mtarg. Com a remoção dos óxidos de ferro amorfos, a maior alteração da carga variável negativa foi observada no LUna ác-mtarg na superficie e na TE em subsuperfície. Entre os latossolos ácricos verificou-se que na superficie a maior variação foi apresentada pelo solo LUna ác-mtarg e na subsuperficie essa variação foi verificada no LR.ác-Gua.

Os valores da carga permanente negativa variaram de 67,0 a 54,4 mmol $_{c} \mathrm{~kg}^{-1}$ para o TE , 20,1 a 16,5 mmol $_{c} \mathrm{~kg}^{-1}$ para o solo LR.ác-Rib; 18,2 a 13,4 mmol $_{\mathrm{c}} \mathrm{kg}^{-1}$ para o LR.ác-Gua; 6,9 a 5,9 mmol $_{\mathrm{c}} \mathrm{kg}^{-1}$ para o solo LUna ác-argare e 58,9 a 36,0 $\mathrm{mmol}_{\mathrm{c}} \mathrm{kg}^{-1}$ para o LUna ác-mtarg. Verifica-se, portanto, que em todos os solos houve decréscimo da carga permanente negativa em profundidade.

O comportamento das cargas permanentes negativas dos solos originais comparado aos solos com óxido de ferro amorfo removido mostra um aumento de 15,9 e 13,3 $\mathrm{mmol}_{\mathrm{c}} \mathrm{kg}^{-1}$ solo para o solo TE; 8,4 e 7,4 $\mathrm{mmol}_{\mathrm{c}} \mathrm{kg}^{-1}$ para o LR ác-Rib; 7,4 e 7,5 mmol $_{\mathrm{c}} \mathrm{kg}^{-1}$ para LR.ác-Gua; 1,1 e $2,2 \mathrm{mmol}_{\mathrm{c}} \mathrm{kg}^{-1}$ para LUna.ác-argare e de 18,3 e 9,9 mmol $_{\mathrm{c}} \mathrm{kg}^{-1}$ para LUna.ác-mtarg para as duas profundidades, o que indica alteração para valores maiores para todos os solos.

De modo idêntico às cargas variáveis e permanentes, os solos estudados apresentaram a carga total reduzida na subsuperficie. Ao comparar os solos originais com os solos com óxido de ferro amorfo removido constata-se que houve um aumento da carga total nas duas profundidades, de 31,9 e 37,0 mmol $\mathrm{kg}^{-1}$ para LRácGua; para a TE; 27 e 24,4 mmol $_{\mathrm{c}} \mathrm{kg}^{-1}$ para o LRác-Rib; 19,3 e 26,2 mmol $_{\mathrm{c}} \mathrm{kg}^{-1}$ 3,8 e 4,0 $\mathrm{mmol}_{\mathrm{c}} \mathrm{kg}^{-1}$ para o LUna ác-argare e de 43,5 e 27,4 $\mathrm{mmnol}_{\mathrm{c}} \mathrm{kg}^{-1}$. para o LUna ác-mtarg. Aumento esse, segundo Fey \& Le Roux (1976) que pode ser atribuído, em parte à quimiosorção dos ânions oxalatos que contribuem para o aumento da CTC bem como, a redução das cargas positivas geradas pelo óxido de ferro amorfo 

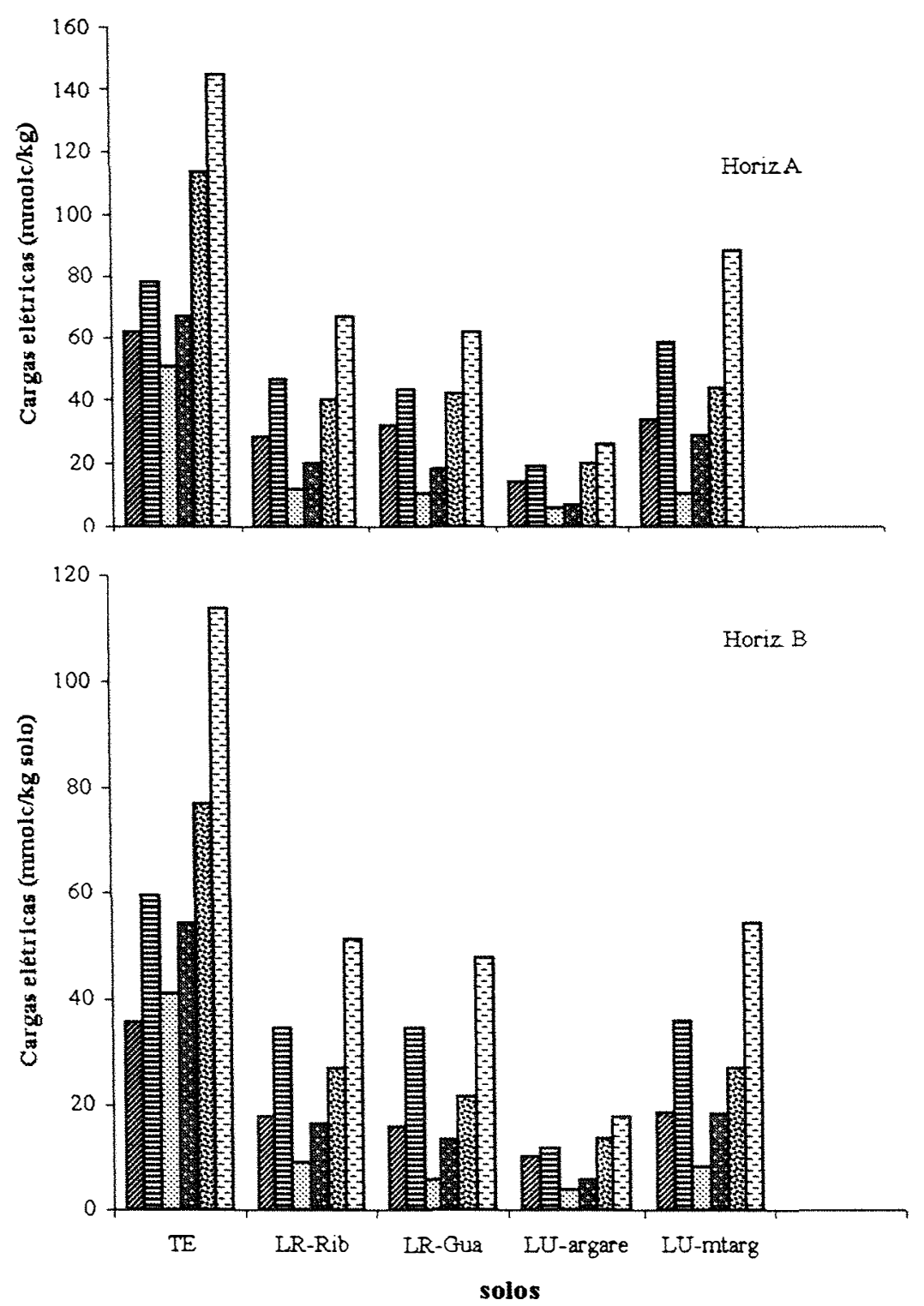

Figura 17 Características das cargas elétricas dos horizontes superficial (A) e subsuperficial (B) dos solos originais $\left(T_{1}\right)$ e dos solos com óxido de ferro amorfo removido $\left(\mathrm{T}_{3}\right)$. 
que segundo Rengasamy \&Oades (1978), Sumner (1962) e ElSwaif (1976) estes óxidos bloqueiam os sítios de troca de cátions reduzindo a CTC.

Portanto, com a remoção do ferro amorfo a capacidade de troca catiônica foi aumentada na seguinte ordem: LUna ác-mtarg $>$ TE $>$ LR ác-Rib $\geq$ LR ác-Gua $>$ LUna ác-argare; mesmo com a remoção do óxido de ferro amorfo os resultados demonstraram que as cargas variáveis e permanentes foram responsáveis respectivamente por, 53 e 47\% na TE; 69 e $31 \%$ no LR ác-Rib; 71 e 29\% no LR ác-Gua e LUna ác-argare e 75 e 33\% no LUna ác-mtarg da carga total das amostras estudadas.

4.5.3 Cargas elétricas após remoção da matéria orgânica e do óxido de ferro livre.

Na Tabela 9 são apresentados os valores calculados das cargas variáveis, permanentes e totais para os solos, após serem submetidos à remoção de matéria orgânica e de óxidos de ferro livres.

Dos valores calculados da carga variável negativa sobre o valor médio entre as duas profundidades verifica-se uma variação de 104,3 a $98,5 \mathrm{mmol}_{\mathrm{c}} \mathrm{kg}^{-1}$ para a TE; 84,9 a $58,8 \mathrm{mmol}_{\mathrm{c}} \mathrm{kg}^{-1}$ para o LR ác-Rib; 8,9 a 38,8 mmol $_{\mathrm{c}} \mathrm{kg}^{-1}$ para o LR ác-Gua; 35,5 a 32,9 $\mathrm{mmol}_{\mathrm{c}} \mathrm{kg}^{-1}$ para o LUna ác-argare e de 68,0 a 48,6 LUna ác-mtarg. Mesmo com a remoção do $\mathrm{Fe}_{\mathrm{d}}$ a tendência da carga variável diminuir em profundidade foi mantida. Verifica-se no entanto, que para o LR ác-Gua a variação dessa carga no perfil foi insignificante $\left( \pm 0,1 \mathrm{mmol}_{\mathrm{c}} \mathrm{kg}^{-1}\right)$ enquanto que, o LUna ác-argare apresentou uma variação de aproximadamente $2,5 \mathrm{mmol}_{\mathrm{c}} \mathrm{kg}^{-1}$ para um teor de Fed de 39 e $43 \mathrm{~g} \mathrm{~kg}^{-1}$ nas duas profundidades.

Ao comparar o comportamento dos solos originais e com os solos onde o ferro livre foi removido (Tabela 9 e Figura 18) observa-se aumento da carga variável negativa nas duas profundidades para todos os solos. Esse aumento foi 
de 42,5 e 62,7 mmol $\mathrm{kg}^{-1}$ para a TE; 56,6 e 41,0 $\mathrm{mmol}_{\mathrm{c}} \mathrm{kg}^{-1}$ para o LR ác-Rib; 6,1 e 23,0 $\mathrm{mmol}_{\mathrm{c}} \mathrm{kg}^{-1}$ para o LR ác- Gua; 21,4 e $22,8 \mathrm{mmol}_{\mathrm{c}} \mathrm{kg}^{-1}$ para o LUna ácargare e de 34,3 e 30,1 mmol $_{\mathrm{c}} \mathrm{kg}^{-1}$ para o LUna ác-mtarg. Portanto, a maior variação da carga variável negativa na superficie, com a ausência da matéria orgânica e dos óxidos de ferro livre, foi observada no LR ác-Rib e na subsuperficie na TE. Entre os latossolos ácricos a maior variação nas duas profundidades foi observada no LR ác-Rib.

A carga permanente negativa aumentou em profundidade para quase todos os solos exceto para o LUna ác-argare. Conforme mostrado na Tabela 9, a variação verificada para os valores calculados da carga permanente negativa sobre o valor médio entre as profundidades foi de 95,8 a 126,9 mmol $_{\mathrm{C}} \mathrm{kg}^{-1}$ para a TE; 37,5 a $56,6 \mathrm{mmol}_{\mathrm{C}} \mathrm{kg}^{-1}$ para o LR ác-Rib; 14,1 a $50,5 \mathrm{mmol}_{\mathrm{C}} \mathrm{kg}^{-1}$ solo para o LR ácGua; 11,5 a 14,4 $\mathrm{mmol}_{\mathrm{C}} \mathrm{kg}^{-1}$ para o LUna ác-argare e de 32,5 a $54,7 \mathrm{mmol}_{\mathrm{C}} \mathrm{kg}^{-1}$ para o LUna ác-mtarg.

Com a remoção do óxido de ferro livre verificou-se que houve aumento das cargas permanentes negativas nas duas profundidades para todos os solos. Os aumentos nas duas profundidades e solos foram de 75,8 e 54,7 $\mathrm{mmol}_{\mathrm{c}} \mathrm{kg}^{-1}$ (TE); 44,9 e $28,4 \mathrm{mmol}_{\mathrm{c}} \mathrm{kg}^{-1}$ (LR ác-Rib); 40,1 e 8,2 $\mathrm{mmol}_{\mathrm{c}} \mathrm{kg}^{-1}$ (LR ác-Gua); 5,7 e 107,0 mmol $_{\mathrm{c}} \mathrm{kg}^{-1}$ (LUna ác-argare); 44,1 e 24,1 mmol $_{\mathrm{c}} \mathrm{kg}^{-1}$ (LUna ác- mtarg). Dos solos estudados o LUna ác-argare, na subsuperficie, e a $\mathrm{TE}$, nas duas profundidades, apresentaram grandes variações e, entre os latossolos ácricos as variações foram verificadas para o LUna ác-argare, LR ác-Rib e LUna ác-mtarg.

Da mesma maneira que comportaram-se as cargas variáveis negativas, as cargas totais mostraram-se diminuídas na subsuperficie em relação à superficie para quase todos solos exceto, para o solo LUna ác-argare onde houve redução na mesma, reflexo do comportamento de sua carga permanente negativa. 
Tabela 9 Cargas efetivas de superfície medidas pela adsorção de Cs em amostras de uma Terra Roxa Estruturada e em solos ácricos com ferro livre removido.

\begin{tabular}{|c|c|c|c|c|}
\hline & Prof $(\mathrm{cm})$ & $-\sigma_{\mathrm{H}}{ }^{l}$ & $-\sigma_{0}^{1}$ & $-\sigma_{\text {Total }}{ }^{1}$ \\
\hline \multirow{4}{*}{$\mathrm{TE}$} & & \multicolumn{3}{|c|}{-..---mmoldkg ${ }^{-1}$ solo--_-_-_-- } \\
\hline & $0-20$ & $104,3(0,00 ; 45)^{2}$ & $126,9(0,16 ; 55)$ & $231,1(0,16)$ \\
\hline & $75-95$ & $98,5(0,30 ; 51)$ & $95,8(0,16 ; 49)$ & $194,2(0,15)$ \\
\hline & média & $101,4(3,34 ; 47)$ & $111,3(18,06 ; 53)$ & $212,7(26,09)$ \\
\hline \multirow[t]{3}{*}{ LRác-Rib } & $0-20$ & $84,9(0,04 ; 60)$ & $56,6(0,17 ; 40)$ & $141,5(0,23)$ \\
\hline & $100-140$ & $58,8(0,11 ; 61)$ & $37,5(0,97 ; 39)$ & $96,3(1,08)$ \\
\hline & média & $71,9(1,06 ; 60)$ & $47,0(10,90 ; 40)$ & $118,9(31,9)$ \\
\hline \multirow[t]{3}{*}{ LRác-Guaí } & $0-20$ & $38,9(0,09 ; 42)$ & $50,5(0,00 ; 56)$ & $89,4(0,01)$ \\
\hline & $100-150$ & $38,8(0,02 ; 73)$ & $14,1(0,01 ; 27)$ & $52,9(0,01)$ \\
\hline & média & $38,8(0,04 ; 55)$ & $32,3(21,0 ; 45)$ & $71,2(25,8)$ \\
\hline \multirow{3}{*}{$\begin{array}{l}\text { LUna } \\
\text { ac-argare }\end{array}$} & $0-20$ & $35,5(0,03 ; 76)$ & $11,5(0,02 ; 24)$ & $47,0(0,01)$ \\
\hline & $30-70$ & $32,9(0,16 ; 70)$ & $14,4(0,01 ; 30)$ & $47,3(0,01)$ \\
\hline & média & $34,2(1,53 ; 72)$ & $13,0(1,67 ; 28)$ & $47,1(0,17)$ \\
\hline \multirow{3}{*}{$\begin{array}{l}\text { LUna } \\
\text { ác-mtarg }\end{array}$} & $0-20$ & $68,0(0,03 ; 55)$ & $54,7(1,31 ; 45)$ & $122,8(1,43)$ \\
\hline & $60-90$ & $48,6(0,09 ; 60)$ & $32,5(0,07 ; 40)$ & $81,1(0,02)$ \\
\hline & média do perfil & $58,3(11,2 ; 57)$ & $43,6(13,4 ; 43)$ & $101,9(29,4)$ \\
\hline
\end{tabular}

:- $\sigma_{\mathrm{H}}=$ adsorção do íon $\mathrm{Cs}^{+}$para os sítios de carga variáveis; $-\sigma_{0}=$ adsorção do íon $\mathrm{Cs}^{+}$para sítios de carga permanente $\mathrm{e}-\sigma_{\mathrm{TOTAL}}=$ adsorção do ion $\mathrm{Cs}^{+}$para sítios de carga total.

${ }^{2}$ : valores entre parêntese representam desvio padrão e participação em percentagern de.$-\sigma_{H}$ e $-\sigma_{0}$ na carga total. 


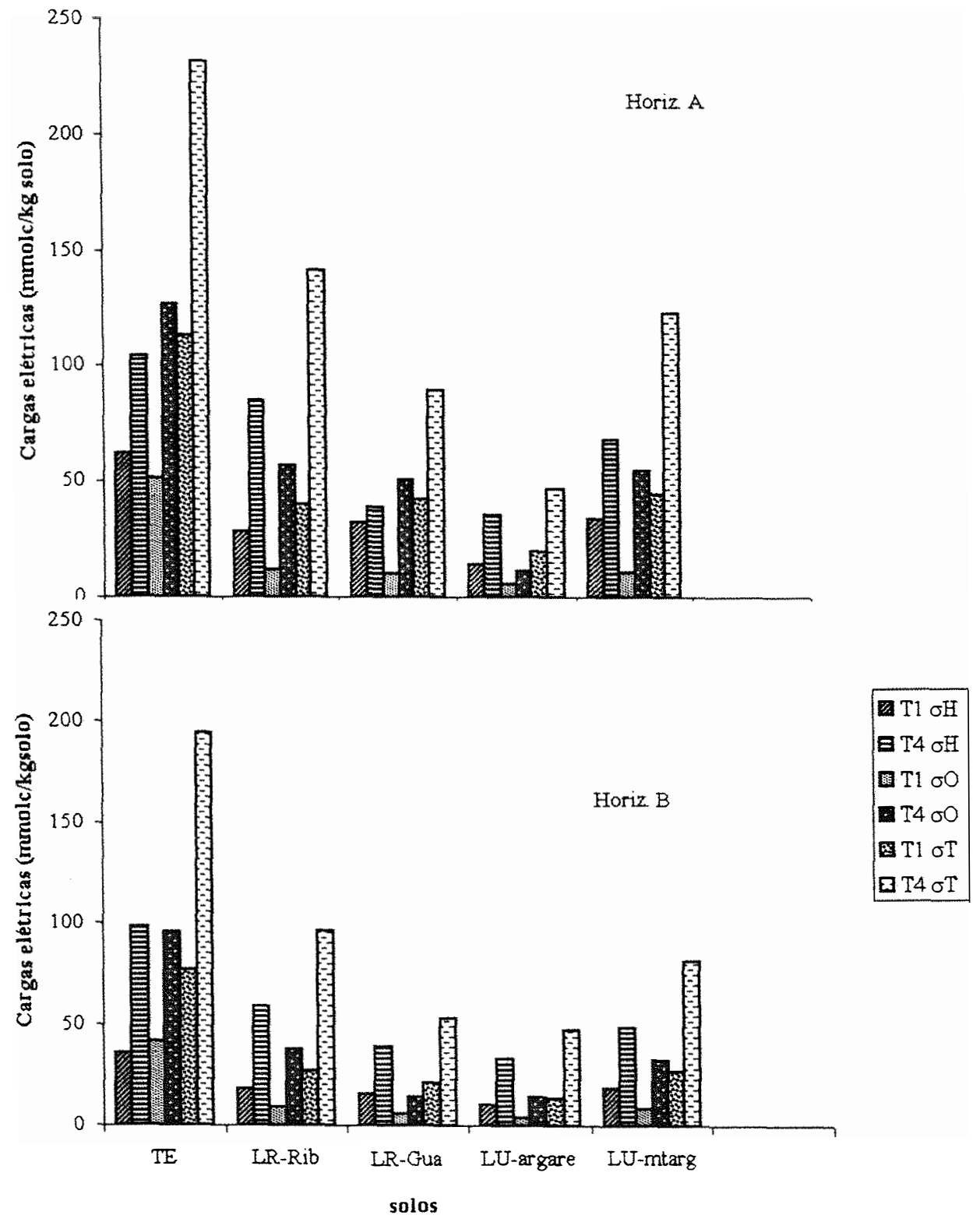

Figura 18 Características das cargas elétricas dos horizontes superficial (A) e subsuperficial $(B)$ dos solos originais $\left(T_{1}\right)$ e dos solos com óxido de ferro amorfo removido $\left(\mathrm{T}_{4}\right)$. 
Comparando-se os valores das cargas totais dos solos originais com os solos com ferro livre removido nota-se que houve um grande aumento nas duas profundidades para todos os solos destacando-se o LR ác-Rib que apresentou um aumento na $-\sigma_{\text {Total }}$ de cerca de três vezes e meia. Os resultados dos solos estudados estão em concordância com Itami et al., (1996) que obtiveram aumento nas cargas elétricas ao deferrificarem suas amostras.

À princípio esperava-se que a deferrificação levaria à diminuição da cargas negativas no sistema. Entretanto, há evidências, segundo Schofield \& Samson (1953), que mostram que os óxidos de ferro têm uma densidade de carga de superficie que varia de $0,5 \times 10^{-7}$ a $1,0 \times 10^{-7} \mathrm{cmol} / \mathrm{cm}^{2}$, enquanto que a densidade de carga para as arestas da caulinita é de cerca de $5 \times 10^{-7} \mathrm{cmol} / \mathrm{cm}^{2}$.

Em virtude destas diferenças de densidade de carga, duas prováveis explicações podem ser dadas segundo Davidtz \& Sumner (1965) e Sumner (1964) aos acréscimos obtidos para as três cargas no presente estudo: (1) extração dos óxidos de ferro que se encontravam ligados à caulinita pela neutralização parcial das cargas das arestas, conduzindo a um aumento tanto da carga negativa quanto da positiva; (2) desbloqueio fisico causado pelo recobrimento do óxido de ferro sobre as cargas negativas da argila, sem mútua neutralização das cargas (Davidtz \& Sumner, 1965). A remoção dos óxidos de ferro resultaria na exposição das arestas do argilomineral. Como estes grupos ligados às arestas são anfotéricos (Schofield \& Samson, 1953), pode-se esperar que com a deferrificação, ocorra um acréscimo ou decréscimo na carga positiva ou negativa, dependendo do valor $\mathrm{pH}$ do sistema e do respectivo ponto isoelétrico (p.i.e) do óxido de ferro e das arestas do argilomineral. A carga negativa aumenta com a deferricação se o pH estiver abaixo do p.i.e do óxido de ferro enquanto, próximo do p.i.e das arestas do argilomineral há um considerável bloqueamento do plano basal.

Como exemplo cita-se, o p.i.e encontrado, por Fey \& Le Roux (1976), para um oxissolo (Latossolo Roxo) da região de Ribeirão Preto, foi de 5,9; ponto este, 
próximo dos $\mathrm{pHs}$ de trabalho do presente estudo $(5,80 ; 5,95)$ e acima do PESN $(5,65)$ obtido por Alleoni (1992) para os latossolos roxos, levando em parte a um bloqueamento físico do mineral de argila 1:1 conforme Schofield \& Samson, (1953); Davidtz \& Sumner (1965) e Sumner (1964).

Desta forma, mesmo com a remoção da matéria orgânica e dos óxidos de ferro pode-se observar que as cargas variáveis ainda preponderaram sobre as permanentes cujos valores médios das cargas variável e permanente são respectivamente, os seguintes: 60,4 e 39,6 \% no LR ác-Rib, 55 e 45\% no LR ácGua, 73 e $27 \%$ no LUna ác-argare e de 57 e $43 \%$ no LUna ác-mtarg, com exceção da TE cuja carga de maior domínio foi a permanente com $52 \%$ contra $48 \%$ da variável.

\subsection{Coeficientes de seletividade condicional ( $\mathrm{K}_{\mathrm{EX}}$ ) para a troca $\mathrm{Li}^{+} \rightarrow \mathrm{Cs}^{+} \mathrm{em}$ solos com matéria orgânica e óxidos de ferro amorfos e livres removidos.}

Os coeficientes de seletividade obtidos para os solos sem matéria orgânica e sem os óxidos de ferro estão apresentados nas Tabelas 10 a 12 e ilustrados na Figura 19. A fração molar do lítio e as concentrações molares do íon césio e lítio nas soluções, encontram-se apresentadas nos Apêndices 2 a 4 .

4.6.1 Coeficientes de seletividade condicional $\left({ }^{c} \mathrm{~K} E \mathrm{EX}\right.$ ) para a troca $\mathrm{Li}^{+} \rightarrow \mathrm{Cs}^{+} \mathrm{em}$ solos com a matéria orgânica removida.

De modo semelhante aos solos originais, houve aumento nos valores dos coeficientes de seletividad em quase todos os solos, exceto o LR ác-Rib. Nota-se que ao remover a pouca matéria orgânica presente em profundidade a afinidade 
dos minerais ao íon césio em relação ao lítio aumentou muito. Assim, o coeficiente de seletividade ( ${ }^{C} \mathrm{~K}_{\mathrm{EX}}$ ) para os solos tratados variaram da seguinte forma: 32,3 a 38,6 para a TE; 13,1 a 17,4 para o LR ác-Gua; 21,4 a 25,2 para o LUna ác-argare e 19,1 a 20,9 para o LUna ác-mtarg. O LR ác-Rib foi exceção comportando-se de forma inversa $(10,0$ a 7,3$)$.

Ao comparar os coeficientes de seletividade condicionais dos solos originais com os solos onde se removeu a matéria orgânica verifica-se que a TE apresentou aumento na seletividade ao íon césio passando de 10,6 para 32,3 na superficie e de 26,4 para 38,6 na subsuperficie; para o LR ác-Rib houve redução tanto na superficie quanto na subsuperfície passando de 12,0 para 10,0 e de 23,9 para 7,3 respectivamente; para o LR ác-Gua ocorreu aumento na superficie passando de 8,3 para 13,1 e redução em profundidade passando de 19,7 para 17,4; para o solo LUna ác-argare ocorreu redução na seletividade em ambas profundidades passando de 24,5 para 21,4 e de 30,8 para 25,2; finalmente para 0 LUna ác- mtarg ocorreu aumento bastante acentuado na superficie passando de 7,6 para 19,1 enquanto que na subsuperficie o aumento foi pequeno passando de 20,4 para 20,9 .

Notou-se que a matéria orgânica para a TE pode servir como barreira para a seletividade catiônica de sua fração mineral, observando-se acentuado aumento no seus coeficientes e por apresentar elevada superficie específica nas duas profundidades (61 e $53 \mathrm{~m}^{2} / \mathrm{g}$ ) (Tabela 5) esta fração pode expor ainda mais seus sítios de troca devido a provável presença, como impurezas, de minerais 2:1 na superficie predominantemente caulinitíca em relação aos solos ácricos estudados (Lim et al., 1980).

Nos latossolos roxos a seletividade foi maior em profundidade para o LRác-Gua observando-se que a fração orgânica influiu muito mais na superfície que na subsuperfície. Já o LRác-Rib teve uma queda bastante acentuada na selitividade, evidenciando que a fração orgânica consituiu-se no principal gerador 
Tabela 10. Coeficientes de seletividade condicionais ( ${ }^{C} K_{E X}$ ) e frações molares $(x C s)$ para a troca $\mathrm{Li}^{+} \rightarrow \mathrm{Cs}^{+}$em uma Terra Roxa Estruturada e dos solos ácricos originais e com matéria orgânica removida.

\begin{tabular}{|c|c|c|c|c|c|}
\hline \multirow[t]{2}{*}{ Solo } & \multirow[t]{2}{*}{ Prof $(\mathrm{cm})$} & ${ }^{\mathrm{c}} \mathrm{Kex}$ & $x \mathrm{Cs}$ & ${ }^{\mathrm{C}} \mathrm{Kex}$ & $x \mathrm{Cs}$ \\
\hline & & \multicolumn{2}{|c|}{ Tratamento $1^{1}$} & \multicolumn{2}{|c|}{ Tratamento $2^{2}$} \\
\hline \multirow[t]{3}{*}{$\mathrm{TE}$} & $0-20$ & $10,6(0,3)^{5}$ & $0,45(0,00)$ & $32,3(0,6)$ & $0,50(0,00)$ \\
\hline & $75-95$ & $26,4(0,9)$ & $0,53(0,00)$ & $38,6(8,1)$ & $0,50(0,00)$ \\
\hline & média & $18,5(11,1)$ & $0,49(0,05)$ & $35,4(4,4)$ & $0,50(0,00)$ \\
\hline \multirow[t]{3}{*}{ LRác-Rib } & $0-20$ & $12,0(0,9)$ & $0,29(0,01)$ & $10,0(0,4)$ & $0,37(0,01)$ \\
\hline & $100-140$ & $23,9(2,5)$ & $0,33(0,01)$ & $7,3(0,8)$ & $0,31(0,02)$ \\
\hline & média & $17,9(8,4)$ & $0,31(0,03)$ & $8,6(1,9)$ & $0,34(0,04)$ \\
\hline \multirow[t]{3}{*}{ LRác-Guaí } & $0-20$ & $8,3(0,4)$ & $0,24(0,00)$ & $13,1(0,4)$ & $0,32(0,00)$ \\
\hline & $100-150$ & $19,7(0,2)$ & $0,27(0,00)$ & $17,4(0,3)$ & $0,32(0,00)$ \\
\hline & média & $14,0(8,1)$ & $0,26(0,02)$ & $15,2(3,0)$ & $0,32(0,00)$ \\
\hline \multirow[t]{3}{*}{ LUna ác-argare } & $0-20$ & $24,5(1.9)$ & $0,29(0,01)$ & $21,4(2,5)$ & $0,26(0,02)$ \\
\hline & $30-70$ & $30,8(1.7)$ & $0,26(0,00)$ & $25,2(2,4)$ & $0,30(0,01)$ \\
\hline & média & $27,6(4.5)$ & $0,28(0,02)$ & $23,3(2,7)$ & $0,28(0,02)$ \\
\hline \multirow[t]{3}{*}{ LUna ác-mtarg } & $0-20$ & $7,6(0,3)$ & $0,24(0,00)$ & $19,1(2,3)$ & $0,38(0,02)$ \\
\hline & $60-90$ & $20,4(0,8)$ & $0,31(0,00)$ & $20,9(0,3)$ & $0,37(0,00)$ \\
\hline & média & $14,0(9,1)$ & $0,27(0,05)$ & $20,0(1,2)$ & $0,38(0,00)$ \\
\hline
\end{tabular}

Tratamento $1=$ solo natural, ${ }^{2}$ tratamento $2=$ com matéria orgânica removida; ${ }^{3}$ valores entre parênteses representam desvio padrão. 
de carga negativa posto que este solo é predominantemente gibbsítico e com baixa quantidade de minerais $2: 1$ (Tabela 5 ).

Entre os latossolos Unas, a seletividade cationnica foi maior para o LUna ác-argare nas duas profundidades em comparação ao LUna ác-mtarg. Com a remoção da matéria orgânica, o LUna ác-argare apresentou maior seletividade na subsuperfície ao passo que o LUna ác-mtarg o aumento foi verifcado na superficie, demonstrando que a espécie orgânica, componente do solo total, era de baixa afinidade ao íon césio, na subsuperficie a remoção da matéria orgânica variou muito pouco a seletividade.

Dentro do princípio $\mathrm{HSAB}$ a fração mineral da $\mathrm{TE}$, onde se removeu a matéria orgânica, é mais polarizável que o LRác-Rib haja vista que o primeiro solo é caulinítico com ki variando entre 1,89 e 1,74 e o segundo mais oxídico com menor ki variando 0,93 a 0,87. Entre os ácricos, o LRác-Guaíra e o LUna ác-argare foram os solos mais polarizáveis entre os latossolos Roxos e Unas respectivamente. Isto significa que a superficie dos dois solos ácricos citados como polarizáveis apresentam-se com superfície mais moles em relação seus pares dentro de cada classe estudada.

4.6.2 Coeficientes de seletividade condicionais $\left({ }^{C} \mathrm{~K}_{\mathrm{EX}}\right.$ ) para a troca $\mathrm{Li}^{+} \rightarrow \mathrm{Cs}^{+}$em uma Terra Roxa Estruturada e em solos ácricos com os óxido de ferro amorfos e livres removidos.

Dentro do tratamento T3 (Tabela 11), onde o óxido de ferro amorfo foi removido, a seletividade pelo íon césio para todos os solos apresentou-se aumentada em profundidade, indicando aumento de preferência pelo íon césio em relação a lítio. Desse modo, a variação do $\left({ }^{C} \mathrm{~K}_{\mathrm{EX}}\right)$ para os solos tratados com a solução Tam apresentaram os seguintes valores: 8,63 a 12,33 para a TE; 7,47 a 11,23 para o LR ác-Rib; 20,4 a 26,9 para LR ác-Gua; 5,93 a 11,66 para o LUna 
ác-argare e de 55,05 a 92,24 para o LUna ác-mtarg. Nota-se que os solos LUna ác-argare e LUna ác-mtarg apresentaram-se menos seletivos ao íon césio, enquanto que para os solos TE, LR ác-Rib e LR ác-Gua a seletividade foi preferencialmente pelo césio.

Tabela 11. Coeficientes de seletividade condicionais $\left({ }^{C} K_{E X}\right)$ e frações molares $(x \mathrm{Cs})$ para a troca $\mathrm{Li}^{+} \rightarrow \mathrm{Cs}^{+}$em uma Terra Roxa Estruturada e dos solos ácricos originais e com óxido de ferro amorfo removido.

\begin{tabular}{|c|c|c|c|c|c|}
\hline \multirow[t]{2}{*}{ Solo } & \multirow[t]{2}{*}{ Prof $(\mathrm{cm})$} & ${ }^{c} \mathrm{Kex}$ & $x \mathrm{Cs}$ & ${ }^{\mathrm{c}} \mathrm{Kex}$ & $x \mathrm{Cs}$ \\
\hline & & \multicolumn{2}{|c|}{ Tratamento 1} & \multicolumn{2}{|c|}{ Tratamento $3^{2}$} \\
\hline \multirow[t]{3}{*}{$\mathrm{TE}$} & $0-20$ & $10,6(0,3)^{5}$ & $0,45(0,00)$ & $8,6(0,4)$ & $0,46(0,01)$ \\
\hline & $75-95$ & $26,4(0,9)$ & $0,53(0,00)$ & $12,4(0,5)$ & $0,48(0,00)$ \\
\hline & média & $18,5(11,1)$ & $0,49(0,05)$ & $10,5(2,6)$ & $0,47(0,01)$ \\
\hline \multirow[t]{3}{*}{ LRác-Rib } & $0-20$ & $12,0(0,9)$ & $0,29(0,01)$ & $7,5(1,7)$ & $0,29(0,04)$ \\
\hline & $100-140$ & $23,9(2,5)$ & $0,33(0,01)$ & $11,2(0,5)$ & $0,32(0,01)$ \\
\hline & média & $17,9(8,4)$ & $0,31(0,03)$ & $9,4(2,6)$ & $0,31(0,02)$ \\
\hline \multirow[t]{3}{*}{ LRác-Guaí } & $0-20$ & $8,3(0,4)$ & $0,24(0,00)$ & $20,4(2,8)$ & $0,52(0,04)$ \\
\hline & $100-150$ & $19,7(0,2)$ & $0,27(0,00)$ & $26,9(2,1)$ & $0,53(0,02)$ \\
\hline & média & $14,0(8,1)$ & $0,26(0,02)$ & $23,7(4,6)$ & $0,52(0,01)$ \\
\hline \multirow[t]{3}{*}{ LUna ác-argare } & $0-20$ & $24,5(1.9)$ & $0,29(0,01)$ & $5,9(0,4)$ & $0,10(0,01)$ \\
\hline & $30-70$ & $30,8(1.7)$ & $0,26(0,00)$ & $11,6(0,4)$ & $0,14(0,02)$ \\
\hline & média & $27,6(4.5)$ & $0,28(0,02)$ & $8,8(4,0)$ & $0,12(0,02)$ \\
\hline \multirow[t]{3}{*}{ LUna ác-mtarg } & $0-20$ & $7,6(0,3)$ & $0,24(0,00)$ & $55,0(2,3)$ & $0,33(0,01)$ \\
\hline & $60-90$ & $20,4(0,8)$ & $0,31(0,00)$ & $92,2(4,4)$ & $0,34(0,00)$ \\
\hline & média & $14,0(9,1)$ & $0,27(0,05)$ & $73,7(26,2)$ & $0,34(0,01)$ \\
\hline
\end{tabular}

7 Tratamento $1=$ solo original, ${ }^{2}$ tratamento $3=$ com óxido de ferro amorfo removidao 3 valores entre parênteses representam desvio padrão. 
Dentro do tratamento com ferro amorfo removido observou-se que o LR ác-Gua e o LUna ác-mtarg foram os mais seletivos ao ín césio o que pode estarrelacionados aos respectivos teores médios de $\mathrm{Fe}$ amorfo nas duas profundidades (14,5 e 7,5 $\mathrm{g} / \mathrm{kg}$ solo), influenciando, provavelmente, no recobrimento superficial dos seus respectivos argilominerais.

Observou-se que essa forma de ferro para esses dois solos pode atuar como neutralizadores das cargas negativas originadas não só da fração orgânica como também dos argilominerais.

Para os demais solos, a remoção do ferro amorfo representou pouco quanto à seletividade na camada superficial apresentando uma variação de 5,9, 7,5 e 8,6 para a TE, Lác-Rib e LUna ác-argare respectivamente. Nas camadas subsuperficiais a fração mineral sem o ferro amorfo teve seus coeficientes de seletividade aumentados. Isto pode ser atribuído, possivelmente, a eliminação de um dos geradores de cargas positivas, o ferro amorfo, segundo Sumner (1962), El Swaif (1976) e Rengasamy \& Oades (1978) que consideram que os aumentos na capacidade de troca cationnica que por sua vez influi na seletividade se devem ao bloqueamento das cargas permanentes negativas dos argilominerais.

Comparando-se os solos originais com os sem ferro amorfo (Figura 19) observou-se que houve redução para quase todos os solos, exceto o LUna ácmtarg, que apresentou elevados aumentos nas duas profundidades. Aos decréscimos, principalmente na superficie, pode-se atribuir ao meio ácido em que foi feita a remoção e a remoção da matéria orgânica que, possivelmente, encontrava-se complexada com o ferro amorfo. Por outro lado, atribui-se a esse aumento da seletividade para o LUna ác-mtarg à maior exposição de sítios de troca dos argilominerais como também à formação de complexos do ânion oxalato com as cargas positivas do solo. 

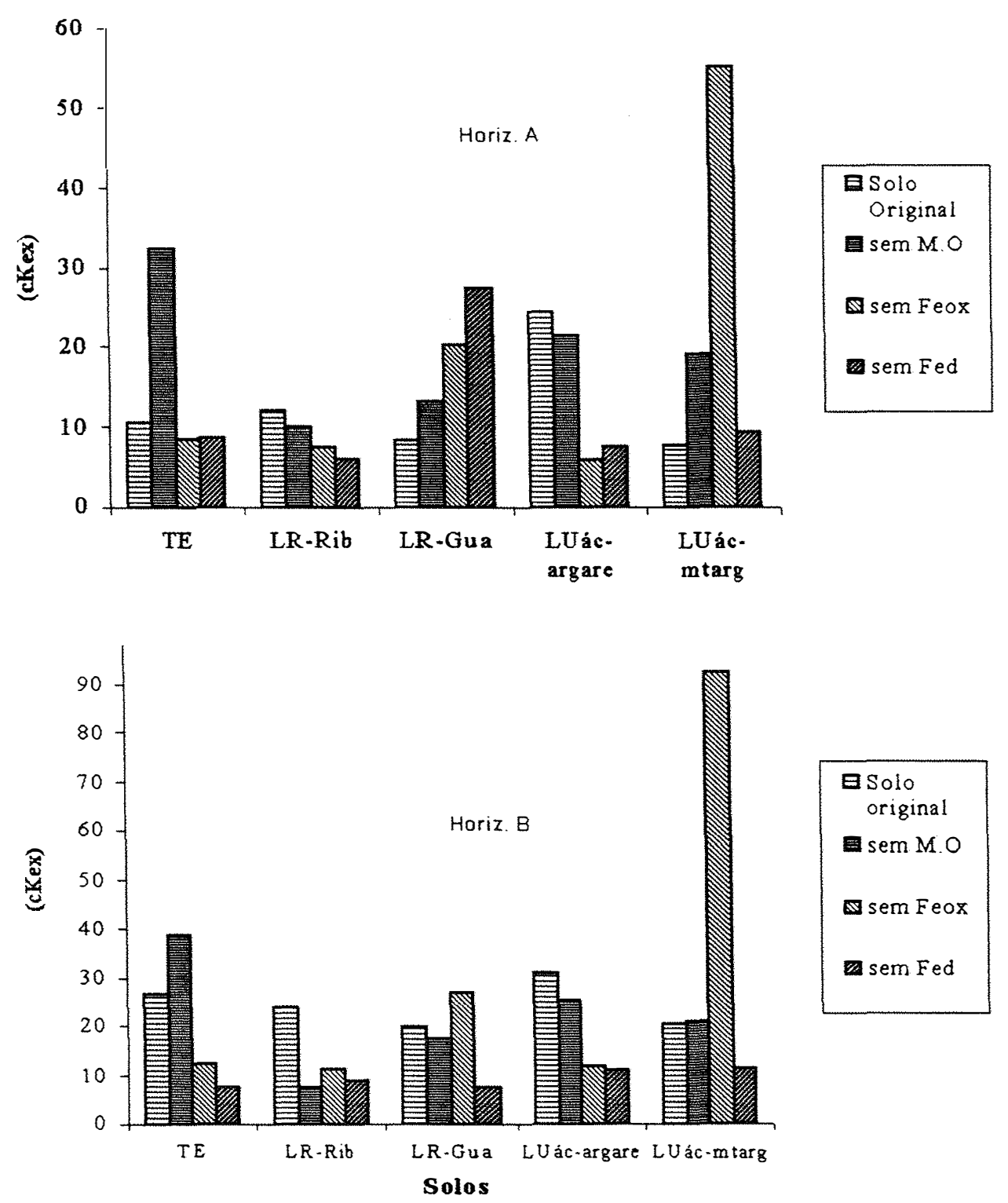

Figura 19 Comparação entre os coeficientes de seletividade con dicionais ( ${ }^{\mathrm{C}} \mathrm{K}_{\mathrm{E}} \mathrm{x}$ ) para a troca $\mathrm{Li}^{+} \rightarrow \mathrm{Cs}^{+}$os solos originaiscom matéria orgânica e óxidos de ferro amorfos e livres removidos estudados. 
Dentro do tratamento T4 (Tabela 12) observou-se que LR ác-Gua revelou ${ }^{c} \mathrm{~K}_{\mathrm{EX}}$ elevado em relação aos demais solos na camada superficial talvez por ter maior quantidade de minerais $2: 1$ + amorfos em relação a caulinita (Tabela 5), mesmo sendo o solo ácrico mais intemperizado. Na camada subsuperficial a remoção do ferro livre levou a observar que os ${ }^{C} K_{\mathrm{EX}}$ dos Latossolos Unas foram maiores que dos Latossolos Roxos, os quais, por sua vez foram iguais à TE. Isto indica que a fração mineral do Latossolos Unas foi mais seletiva ao ín césio que os Latossolos Roxos, cujas superficies são mais polarizáveis que estes últimos.

Ao comparar os solos com ferro livre removido com os solos originais, pode-se observar que os coeficientes da TE, LR ác-Rib e do LUna ác-argare na camada superficial diminuiram ao passo que o LR ác-Gua e LUna ác-mtarg aumentaram, sendo uma possível explicação a presença de minerais 2:1 + amorfos nestes dois últimos solos.

Já na subsuperficie a seletividade esteve diminuída para todos os solos demonstrando que a fração mineral contendo óxido de ferro livre é altamente seletiva talvez, devido à oxidação prévia da matéria orgânica, operação esta necessária para uma remoção bem sucedida do ferro livre.

Para que um adsorvente tenha um comportamento ideal, os coeficientes de atividade de superficie para uma troca binária de mesma carga deve apresentar valor constante de uma unidade e o coeficiente de seletividade também deve apresentar um valor constante para todas composições de superficie (Gast,1972). No entanto, este comportamento não foi observado no estudo dos solos originais e nos estudos onde a matéria orgânica e os óxidos de ferro amorfos e livres foram removidos e nem tem sido observado nas reações de troca monovalentemonovalente em todos os cátions do grupo IA (Sawhney, 1972; Gast, 1972; Comans, 1991; Chorover, 1993; McBride, 1994). 
Tabela 12. Coeficientes de seletividade condicionais $\left(C_{\mathrm{EX}}\right)$ e frações molares $(x \mathrm{Cs})$ para a troca $\mathrm{Li}^{+} \rightarrow \mathrm{Cs}^{+}$em uma Terra Roxa Estruturada e dos solos ácricos originais e com óxido de ferro livre removido.

\begin{tabular}{|c|c|c|c|c|c|}
\hline \multirow[t]{2}{*}{ Solo } & \multirow[t]{2}{*}{ Prof $(\mathrm{cm})$} & ${ }^{c} \mathrm{Kex}$ & $x \mathrm{Cs}$ & ${ }^{c} \mathrm{Kex}$ & $x \mathrm{Cs}$ \\
\hline & & \multicolumn{2}{|c|}{ Tratamento 1} & \multicolumn{2}{|c|}{ Tratamento $4^{2}$} \\
\hline \multirow[t]{3}{*}{$\mathrm{TE}$} & $0-20$ & $10,6(0,3)^{5}$ & $0,45(0,00)$ & $8,8(0,01)$ & $0,55(0,00)$ \\
\hline & $75-95$ & $26,4(0,9)$ & $0,53(0,00)$ & $7,5(0,04)$ & $0,49(0,01)$ \\
\hline & média & $18,5(11,1)$ & $0,49(0,05)$ & $8,1(0,93)$ & $0,52(0,04)$ \\
\hline \multirow[t]{3}{*}{ LRác-Rib } & $0-20$ & $12,0(0,9)$ & $0,29(0,01)$ & $6,0(0,03)$ & $0,40(0,00)$ \\
\hline & $100-140$ & $23,9(2,5)$ & $0,33(0,01)$ & $8,6(0,20)$ & $0,39(0,00)$ \\
\hline & média & $17,9(8,4)$ & $0,31(0,03)$ & $7,4(1,81)$ & $0,39(0,00)$ \\
\hline \multirow[t]{3}{*}{ LRác-Guai } & $0-20$ & $8,3(0,4)$ & $0,24(0,00)$ & $27,3(0,01)$ & $0,57(0,00)$ \\
\hline & $100-150$ & $19,7(0,2)$ & $0,27(0,00)$ & $7,7(0,01)$ & $0,27(0,00)$ \\
\hline & média & $14,0(8,1)$ & $0,26(0,02)$ & $17,5(13,9)$ & $0,41(0,21)$ \\
\hline \multirow[t]{3}{*}{ LUna ác-argare } & $0-20$ & $24,5(1.9)$ & $0,29(0,01)$ & $7,5(0,02)$ & $0,24(0,00)$ \\
\hline & $30-70$ & $30,8(1.7)$ & $0,26(0,00)$ & $11,0(0,01)$ & $0,30(0,00)$ \\
\hline & média & $27,6(4.5)$ & $0,28(0,02)$ & $9,3(2,46)$ & $0,27(0,04)$ \\
\hline \multirow[t]{3}{*}{ LUna ác-mtarg } & $0-20$ & $7,6(0,3)$ & $0,24(0,00)$ & $9,3(0,22)$ & $0,45(0,01)$ \\
\hline & $60-90$ & $20,4(0,8)$ & $0,31(0,00)$ & $11,2(0,04)$ & $0,40(0,00)$ \\
\hline & média & $14,0(9,1)$ & $0,27(0,05)$ & $10,3(1,30)$ & $0,42(0,03)$ \\
\hline
\end{tabular}

Tratamento $1=$ solo original, ${ }^{2}$ tratamento $4=$ com óxido de ferro livre removido ${ }^{3}$ valores entre parênteses representam desvio padrão. 


\section{CONCLUSÕES}

Os resultados do presente trabalho permitiram concluir:

a) A porcentagem da carga variável representou mais que $50 \%$ das cargas totais dos solos originais avaliados. Eles revelaram um valor mínimo de 55\% para a TE e um máximo de $77 \%$ para o LUna ác-mtarg para a camada superfical. Para a camada mais profunda, eles apresentaram um valor mínimo de $47 \%$ para a $\mathrm{TE}$ e um máximo de 73\% para ambos os solos, LR ác-Gua e LUna ác-argare. Os latossolos ácricos exibiram significante quantidade de carga permanente a qual foi pode ser atribuída à baixas quantidades de vermiculita com hidróxido de alumínio nas entrecamadas e de clorita, ambos detectados pela DRX. A quantidade de carga permanente apresentada pela TE comparada ao Latossolo ácGua foi cinco vezes superior que é devido, provavelmente, à diferença mineralógica. Aproximadamente 23 a $34 \%$ das cargas negativas a $\mathrm{pH} 6,0$ dos latossolos ácricos e 45 a 53\% da TE resultou da contribuição das cargas permanentes. Considerando os Latossolos Roxos ácricos a carga permanente diminuiu à medida que o índice de intemperização (ki) diminuiu exceto para os Latossolos ácricos variação Una. A complexação do césio pela matéria orgânica conduziu a valores de carga permanente superestimados. A carga negativa a $\mathrm{pH}$ 6,0 é amplamente derivada de grupos funcionais inorgânicos e orgânicos com grande preferência por césio sobre lítio. 
b) Nos solos onde a matéria orgânica foi removida, as cargas variáveis apresentaram-se reduzidas na superfície, exceção do LUna ác-argare que manteve essa mesma quantidade de carga e, aumentadas na subsuperficie. As cargas permanentes na superficie diminuíram para os solos TE e LUna ác-argare para os demais houve aumento. Estas cargas aumentaram para todos os solos na subsuperficie. As cargas totais mostraram predomínio das cargas variáveis nas duas profundidades para quase todos os solos, exceto a TE. Este solo mostrou predomínio das cargas permanentes sobre as variáveis em profundidade, refletindo igual participação dos dois tipos de cargas na capacidade de troca cationnica.

c) Nos solos onde os óxidos de ferro amorfos e livres foram removidos todas as cargas aumentaram nas duas profundidades e para todos os solos avaliados. As cargas permanentes apresentaram predomínio sobre as variáveis na camada superficial para quase todos os solos, onde se removeu o ferro livre, exceto os latossolos variação Una. Na subsuperficie a carga variável predominou sobre a permanente para todos os solos para ambos tratamentos. As cargas totais mostraram predomínio das cargas variáveis sobre as permanentes nas duas profundidades para todos os solos e nos dois tratamentos.

d) A contribuição das cargas variáveis pode estar diretamente relacionada com os materiais oxídicos presentes nos perfis, principalmente na forma livre.

e) Nos solos originais e com remoção de agentes cimentantes houve adsorção preferencial ao íon césio. $O$ maior coeficiente de seletividade condicional ao íon césio foi apresentado pelo LUna ác-argare e os menores pelos LR ác-Gua e LUna ác-mtarg. Com a remoção de matéria orgânica, a TE mostrouse mais seletiva ao íon césio e entre os latossolos ácricos, o LUna ác-argare foi o mais seletivo ao césio. Com a remoção dos óxidos de ferro amorfos, o mais seletivo ao íon césio foi o LUna ác-mtarg e com a remoção dos óxidos de ferro livres, o LR ác-Gua foi o que apresentou maior seletividade ao ín césio, e 
independentemente dos tratamentos, os solos se comportaram como trocadores não ideais.

f) O método mostrou-se capaz em quantificar significativa quantidade de carga permanente mesmo em solos com baixas quantidades de minerais 2:1. 


\section{REFERÊNCIAS BIBLIOGRÁFICAS}

AHRLAND, S. Scales of softness for donors and acceptors. Chem. Phys. Lett. v.2, p. 303-306, 1968.

ALLEONI, L. R. F.; CAMARGO, O. A. Pontos de efeito salino nulo de latossolos ácricos. Revista Brasileira de Ciências do Solo, Campinas, v.18, n.2, p.175-180, 1994.

ALLEONI, L.R.F.; CAMARGO, O A. Potencial elétrico superficial e carga líquida de latossolos ácricos. Revista Brasileira de Ciências do Solo, Campinas, v.18, n.2, p. 181-185, 1994.

ALLEONI, L.R.F.; CAMARGO, O. A. Ponto de efeito salino nulo: proposição de nomenclatura. Boletim Informativo SBCS, n.18, p.5-10, 1993.

ALLEONI, L.R.F. Atributos eletroquímicos de solos ácricos do norte paulista. Piracicaba, 1992. 121p. Dissertação (M.S.)-Escola Superior. de Agricultura "Luiz de Queiroz"/ USP.

ANDERSON, S.J.; SPOSITO, G. Proton surface charge density in soils with structural and $\mathrm{pH}$ dependent charge. Soil Science Society of America Journal v. 56, p.1437-1443, 1992. 
ANDERSON, S.J.; SPOSITO, G. Cesium adsorption methods for measuring accessible structural surface charge. Soil Science Society of America Journal, v.55, p.1569-1576, 1991.

ANDERSON, S.J. Variable charge properties of soils containing 2:1 phyllosilicates. California, 1989. 101 p. Dissertation (Doctor)-University of California at Riverside.

ANTONEllo, L. L; MÖlleR, M. R. F.; MONIZ, A. C; DURIEZ, M. A.M. Mineralogia de argilas deferreficadas de "horizonte B" de latossolo do Sudeste e Sul do Brasil. In: REUNIÃO DE CLASSIFICAÇÃO, CORRELAÇÃO DE SOLOS E INTERPRETAÇÃO DE APTIDÃO AGRÍCOLA, 3., Rio de Janeiro, 1988. Anais. Rio de Janeiro, EMBRAPA/SNLCS, 1988. p.185-210. (EMBRAPA. Documentos SNLCS, 12).

ANTONELLO, L. L. Mineralogy of the deferrified clay fraction in B horizon of pedons of the VIII th International Soil Classification Workshop. In: INTERNATIONAL SOIL CLASSIFICATION WORKSHOP. 8., Rio de Janeiro, 1986. Proceedings, Rio de Janeiro, EMBRAPA/ SNLCS, 1988. p. 109-138.

BARNHISEL, R. I; BERTSCH, P. M. Chlorites and hydroxy-interlayed vermiculite and smectite. In: DIXON, J. B \& WEED, S. B (Ed). Mineral in soil environments, Madison, SSSA, 2 ed. p. 729-788, 1989.

BARSHAD, J. The effect of the interlayer cations on the expansion of the mica type of crystal lattice. Analitical Mineral v.35, p. 225-238, 1950. 
BELL, L. C.; GILlMAN, G. P. Surface charge characteristics and soil solution composition of highly weathered soils. In: ANDREW, C. S. \& KAMPRATH, E. J. (Ed). Mineral nutrition of legumes in tropical and subtropical soils. 1978. Melbourne, CSIRO, 1978. p. 37-57.

BENNEMA, J.; JONGERIUS, A.; LEMOS, R. C. Micromorphlogy of some oxic and argilic horizons in South Brazil in relation to weathering sequences. Geoderma v.4, p.333- 358, 1970.

BERTON, R. S. Especiação iônica da solução do solo.- metodologia e aplicações. In: DECHEN, A R; CARMELLO, Q. A. C \& FLOSS, E. L (coords). ANAIS DO II SIMPÓSIO AVANÇADO DE SOLOS E NUTRIÇÃO DE PLANTAS, 1989. p. 17-41.

BERTSCH, P. M.; HUNTER, D. B. Structural environments of Cs adsorbed to clay minerals amd model exchangers. Agronomy Abstracts, 1993. American Society of Agronomy, Madison, W. I.

BERUBE, Y. G; BRUYN, P. L. Adsorption at the rutile solution interface. I. Thermodynamics and experimental study. Journal Colloid Interface Science v.27, p.305-318, 1968.

BOHN, H. L.; McNEAL, B. L ; O'CONNOR, G. A. Soil Chemistry. New York, John Wiley \& Sons, 329p., 1979.

BOLAN, N. S.; NAIDU, R.; SYERS, J. K.; TILLMAN, R. W. Surface charge and solute interactions in soils. Advance in Agronomy, v.67, p. 87-140, 1999.

BOLAN, N. S.; SYERS, J. K.; TILLMAN, R. W.; SCOTTER, D. R. Effect of liming and phosphate additions on sulfate leaching In soils. Journal of Soil Science, Oxford, v.39, n.4, p.493-504, 1988. 
BOLAN, N.S.; SYERS, J.K.; TILLMAN, R.W. Ionic strength effects on surface charge and adsorption of phosphate and sulphate by soils. Journal Soil Science Oxford, v.37, p. 379-388, 1986.

BOLT, G. H.; RIEMSDIJK W. H. van. Surface chemical processes in soil. In: STUMM, W. (Ed.) Aquatic Surface Chemistry: Chemical Processes at the Particle-Water Interface. John Wiley and Sons Inc., New York, 1987.

BOLT, G. H. The ionic distribution in the diffuse double layer. In: BOLT, G. H. (Ed). Soil Chemistry. B. Physico-Chemical Models Second Edition. pp. 1-26. Developments in Soil Science, 5B. Elsevier, New York, 1982.

BOLT, G. H.; RIEMSDIJK W. H. van. Ion adsorption on inorganic variable charge constituents. In: BOLT G.H. (Ed.). Soil Chemistry Part B. Physico-Chemical Models. Developments in Soil Science 5B, Elsevier, New York, p.459-503, 1982.

BOL T, G. H. Cation-exchangeable equations used in soil science. A review. Neth. Journal Agricultural Science, Wageningen v. 15, p.81-103, 1967.

BOLT, G. H; SUMNER, M. E; KAMPHORST, A. A study of the equilibria between three categories of potassium in an illitic soil. Soil Science Society of America Proceeding. v.27, p.294-299, 1963.

BREEUWSMA, A.; LYKLEMA, J. Physical and chemical adsorption of ions In the electrical double layer on hematite $\left(\alpha-\mathrm{Fe}_{2} \mathrm{O}_{3}\right)$. Journal Colloid and Interface Science., v.43, n.2, p. 437-48, 1973.

BRITZ, D.; NANCOLLAS, G. H. Thermodynamics of cation exchange of hydrous zirconia. Journal Inorg. Nucl. Chemestry v.37, p. 3861-3868, 1969. 
BROUWER, E; BAEEYENS, B; MAES, A; CREMERS, A. Cesium and rubidium equilibria in illite clay. Journal Phys. Chem. v.87, p.1213$1219,1983$.

BRUGGENWERT, M. G. M.; KAMPHORST, A. Survey of experimental information on cation exchange in soil systems. In: BOLT, G. H. (Ed) Soil Chemistry, B. Physico-Chemical Model. Second Edition. p.141203. Elsevier, New York, 1982.

CAMARGO, O.A.; ALLEONI, L. R. F. Alguns Métodos e Terminologias em eletroquímica de Solos. In: ALVAREZ, V. H. V.; FONTES, L. E. F.; FONTES, M. P. (Ed). O solo nos grandes domínios morfoclimáticos do Brasil e o desenvolvimento sustentado. Viçosa, 1996. SBBCS, UFV, DPS, p 475-484, 1996.

CAMARGO, O. A.; MONIZ, A. C.; JORGE, J. A.; VAlADARES, J. M. A. Métodos de análise química, mineralógica e física de solos do Instituto Agronômico de Campinas. Campinas, 94p. (IAC-Boletim Técnico,106). 1986.

CAMPBELL, A. S; SCHWERTMANN, U. Iron oxide mineralogy of placic horizons. Journal of Soil Science v.35, p. 569-582, 1984.

CASAGRANDE, J. C. Avaliação de um modelo de complexação de superficie para adsorção de fosfato em solos ácricos do norte paulista. Piracicaba, 1993. 97p. Tese (Doutorado)- Escola Superior de Agricultura "Luiz de Queiroz", Universidade de São Paulo.

CHARLET, L., WERSIN P.; STUMM, W. Surface charge of Mn and $\mathrm{FeCO}_{3}$. Geochimica et Cosmochimica Acta, n. 54, p. 2329-2336, 1990. 
CHARLET, L.; SPOSITO, G. Bivalent ion adsorption by an Oxisol. Soil Science Society of America Journal,. v.53, p. 691-695, 1989

CHARLET, L.; SPOSITO, G. Monovalent ion adsorption by an Oxisol. Soil Science Society of America Journal, v. 51, p.1155-1160,1987.

CHARLET, L. Adsorption of some macronutrients ions on na Oxisol. An application of the triple layer model. California, 1986. 148p. Dissertation (Doctor)- University of California at Riverside.

ChAVES, L. H. G; TRAJANO. M. D. M. Determinação do ponto de carga zero e das cargas elétricas do horizonte Ap de solos do estado da Paraíba. Revista Brasileira de Ciências do Solo, n.16, p.415-418, 1992.

CHOROVER, J.; SPOSITO, G. Surface charge characteristics of kaolinitic tropical soils. Geochemica et Cosmochimica Acta., v.59, n.5, p.875$884,1995 \mathrm{a}$.

CHOROVER, J.; SPOSITO, G. Dissolution behavior of kaolinitic tropical soils. Geochemica et Cosmochimica Acta., v.59, n.5, p.3109-3121, 1995b.

CHOROVER, J. Surface charge and colloidal properties of benchmark Brazilian Oxisols. California, 1993. Thesis (Ph.D)-University of California at Berkeley. 
CHOROVER, J.; SPOSITO, G. Measurement of surface charge components. Technical Reports, NSF grant EAR 9221258, 48 pp. University of California at Berkeley, 1993.

CIHACEK, J. L.; BREMNER, J. M. A simplified ethylene glycol monoethyl ether procedure for assessment of soil surface area. Soil Science of America Journal. v. 43, p. 821-822, 1979.

CLEGG, S. L.; WHITFIELD, M. Activity coefficients in natural waters. Activities coefficients in electrolyte solutions. Boca Raton, 2nd. ed. 1991.

COLEMAN, N. T.; CRAIG, D.; LEWIS D. R. J. Ion exchange reactions of Cesium. Soil Science Society American Proceeding., v.27, p. 287-289, 1963a.

COLEMAN, N. T.; LEWIS, D. R. J.; CRAIG, D. Sorption of cesium by soils and its displacement by salt solutions. Soil Science Society of America Proceeding, v. 27, p. 290-294, 1963 b.

COMANS, R. N. J.; HALlER, M. ; PRETER, P. DE. Sorption of cesium on illite: Non-equilibrium behavior and reversibility. Geochimica et Cosmocimica Acta, .v.55, p.433-440, 1991.

CORNELL, R. M.; SCHWERTMANN, W. The iron oxides. Weinheim; New York, UCH. 1996. 573p.

COSTA, A. C. S. Iron oxide mineralogy of soils derived from colcanic in the Paraná River Basin, Brazil. Columbos- OH, 1996. 220 p. Dissertation (Doctor), Graduate School of the Ohio State University. 
COTTON, F. A.; WILKINSON, G. Advanced inorganic chemistry. 3rd ed. Wiley-Interscience, New York. 1980.

CURI, N. Lithosequence and toposequence of Oxisols from Goias and Minas Gerais, Brazil. Ph.D (Thesis), Perdue University, West Lafayette,IN.

CURTIN, D.; SMILliE, G. W. Origin of the pH-dependent cation exchange capacities of Irish soil clays. Geoderma, v.22, p. 213-224, 1979.

DAVIS, J. A.; LECKIE, J. O. Surface ionization and complexation at the oxide/water interface. III. Adsorption of anions. Journal of Colloid Interface Science. Lancaster, v. 74, p. 32-43, 1980.

DAVIS, J. A; KENT, D. B. Surface complexation modeling in aqueus geochemistry. In: HOCELlA, M. F \& White, A. F (Ed) MineralWater Interface Geochemistry. p.177-260. Reviews in mineralogy, v. 23. Mineralogical Society of America, Washington, D.C.1990.

DAVITZ, J. C.; SUMNER, M. E. Blocked charges on clay minerals in subtropical soils. Journal Soil Science v.16, p.270-274, 1965.

DESPHANDE, T. L.; GREENLAND, D. J.; QUIRK, J. P. Influence of iron and aluminium oxids on the charges of soil and clay material. In: Transactions of 8 th Congress of International Soil Science. Bucharest, v. 3, p. 1213-1225, 1964.

DIXON, J.B.; WEED, S.B. Minerals in Soil Environments. SSSA Book Series, Madison, SSSA. 1989.1271p.

DUQUETTE, M.; HENDERSHOT, W. Soil surface charge evaluation by back-titration: I. Theory and Method Development. Soil Science Society of America. v. 57, p.1222-1228, 1993.

EBERL, D. D. Alkali: cation selectivity and fixation by clay minerals. Clays Clay Minerals v.28, p.161-172, 1980. 
EISENMAN, G. Cation selective glass eletrodes and their mode of operation. Biophysics Journal v.2, p.259-323, 1962.

ELIANSON, J. R. Montmorillonite exchange equilibria with strontiumsodium-cesium. American Mineral v.51, p.324-335, 1966.

ELSON, J.; LUTZ, J.F. Factors affecting agregation of Cecil soil and effect of aggretation on run-off and erosion. Soil Science v.50, p.205-75,1940.

EL-SWAIFY, S.A. Physical and mechanical properties of Oxisols. In: THENG, B. K.G (Ed.) Soils With Variable Charge. p.303-324. New Zealand Soc. Soil Science. Lower Hutt ,1980.

EL-SWAIFY, S.A. Changes in the physical properties of soil clays due to precipitated aluminium and iron hydroxides. 2. Colloidal interactions in the absence of during. Soil Science Society America Journal. v.40, p.516-520, 1976.

EL-SWAIFY, S. A. ; SAYEGH, A. H. Charge characteristics of an Oxisol and an Inceptisol from Hawaii. Soil Science., v.120, p.49-56, 1975.

ESPINOZA, W., GAST R.G. ; ADAMS, Jr R. S. Charge characteristics and nirate retention by two Andepts from southern Chile. Soil Science Society America Proceeding., n.39 p.842-846, 1975.

EVANS, D. W.; ALBERTS, J.; CLARK, R. A.Reversible ionexchange fixation of Cs mobilization from reservoir sediments. Geochimica et Cosmochimica Acta, .v.47, p.1041-1049, 1983.

FEY, .M.V; LE ROUX, J. Eletric Charges on Sesquioxidic Soil Clays. Soil Science Society of America Journal, v.40, p.359-364, 1976.

FOLLET, E. A.C. The retention of amorphous, colloidal "ferric hidroxide"by kaolinites. Journal of Soil Science v. 16, n.2 p. 334-341, 1965. 
FONTES, M.P.F. Caracterização de carga superficial de Latossolos brasileiros de diferentes mineralogias In: CONGRESSO LATINOAMERICANO DE CIÊNCIA DO SOLO, 13. Água de Lindóia, 1996.Solo-suelo 96: palestra. Piracicaba: SBCS/SLCS, 1996.

FONTES, M.P.F.; SPOSITO, G. Medição da densidade de carga estrutural, acessível em Latossolos brasileiros com diferentes mineralogias. In:, CONGRESSO BRASILEIRO DE CIÊNCIA DO SOLO, 25. Anais Viçosa-MG. v. I p.292-294, 1995.

FONTES, M. P. F. Vermiculita ou esmectita com hidróxi nas entrecamadas: proposição de nomenclatura. Boletim Informativo da Sociedade Brasileira do Solo, Campinas. v.15, n.1 p.24-28, 1990.

FORDHAM, A. W.; NORRISH, K. Electron micropobe and electron microscope studies of soil clay particles. Journal Soil Resources v.17, p.283-306, 1979.

GALlEZ, A.; JUO, A. S. R.;. HERBILLON, D A. J. Surface and charge characteristics of selected soils of the tropics. Soil Science Society of American Journal,. n. 40, p.601-608, 1976.

GANGAIYA, P.; MORRISON, R. J. A review of the problems associated with applying the terms surface change and zero point of charge to soils. Communications in Soil Science and Plant Analysis v.18, p.1431-1445, 1987.

GAST, R. G. Surface and colloid chemistry. In: DIXON, J. B. \& WEED, S. B (Ed) Minerals in Soil Environments, 1st ed, p. 27- 73, 1977. 
GAST, R. G. Alkali metal cation exchange on Chambers montmorillonite. Soil Science Society of American Journal, n. 36, p.14-19, 1972.

GAST, R. G. Standard free energies of exchange for alkali metal cations on Wyoming bentonite. Soil Science Society American Proceeding. v 33 p.37-41, 1969.

GHABRU, S. K.; ARNAUD, R. J. ST.; MERMUT, A. R. Association of DCB extractable iron with minerals in coarse soil clays. Soil Science v. 149, n.2 p.112-120, 1990.

GILLMAN, G.P;. SUMNER, M.E. Surface charge characterization and soil solution composition of four soils from the southern Piedmont in Georgia. Soil Science Society of America Journal., n.51, p. 589-594, 1987a.

GILLMAN, G.P;.SINCLAIR, D. F. The grouping of soils with similar charge properties as a basis for agrotechnology transfer. Australian Journal Soil Research, v.25, p. 275,1987b.

GILlMAN, G. P;. SUMPTER, E. A. Modification to the compulsive exchange method for measuring exchange characteristics of soils. Australian Journal Soil Research, v. 24, p. 61, 1986.

GILLMAN, G. P. Using variable charge characteristics to understand the exchangeble cation status of oxidic soils. Australian Journal Soil Resources, v.22, p.71-80, 1984.

GILLMAN, G. P ; UEHARA, G. Charge characteristics of soils with variable and permanent charge mineral: II. Experimental Soil Science Society of America Journal., v. 44., p.252-55, 1980.

GILLMAN, G. P; FOX, R. L. Increases in the cation exchange capacity of variable charge soils following superphosphate applications. Soil Science Society of America Journal., v.44, n.5, p.934-938, 1980. 
GILLMAN, G. P.; BILL, L. C. Surface charge characteristics of six weathered soils from tropical North Queensland. Australian Journal. Soil Research., v. 14, n. 3, p. 351-360, 1976.

GILLMAN, G. P. The influence of net charge on water dispersible clay and sorbed sulphate. Australian Journal of Soil Research, Victoria, v. 12, p.173-176,1974.

GREENLAND, D. J.; MOTT, C. J. B. Surfaces of soil particles.In: GREENLAND, D. J \& HAYES, H. B (Ed). The chemistry of soil constituents. John Wiley \& Sons, Chichester, p. 321-353, 1978.

GREENLAND, D. J Charge characteristics of some kaolinite iron hydroxide complexes. Clay Minerals v.10, p.407-416, 1975.

GREENLAND, D. J. Interactions between humic and fulvic acids and clays. Soil Science. v.111, p.34-41, 1971.

GREENLAND, D. J.; OADES, J. M. Iron hidroxides and clay surfaces. In: Transactions of 9th. CONGRESS of INTERNATIONAL SOILS SCIENCE. Adelaide, v. 1 p.657-668, 1968.

HEALY, T. W.; JAMES, R. O.; COOPER, R. The adsorption of aqueous Co (III) at the silica-water interface. In: Adsorption from Aqueous Solution. Adv. Chem. n. 79, Washington, D.C 1968.

HEALY, T. W.; HERRING, A. P.; FUERSTENAU, D. W. the effect of crystal structure on the surface properties of a series of manganese dioxide. Journal Colloid and Interface Science v.21, p. 435-444, 1966.

HEILMAN. M. D.; CARTER, D. L.; GONZALlEZ, L. L. The ethylene glycol monoethyl ether (EGME) tecnique for determining soil-surface area. Soil Science, Baltimore, v.100, p.409-413, 1965. 
HENDERSHOT, W. H.; LAVKULICH, L. M. Effect of sesquioxide coatings on surface charge of standard mineral and soil samples. Soil Science Society of America Journal. v.47, n. 1252-1260, 1983.

HENDERSHOT, W. H.; LAVKULICH, L M. The effect of sodium chloride saturation and organic matter removal on the value of zero point of charge. Soil Science, v. 128, p.136-141, 1979.

HENDERSHOT, W. H.; LAVKULICH, L. M. The use of zero point of charge (ZPC) to assess pedogenic development. Soil Science Society of America Journal., v.42, n.3, p.468-72, 1978.

HERBILLON, A. J. Introduction to the surface charge properties of iron oxides and oxidic soils. p.251-264. In: J.W. STUCKI et al. (eds.). Iron in soils and clay minerals. NATO Adv. St. Inst., Série C. Vol. 217. Reidel Publ. Co., Boston, MA. 1988.

HERBILLON, A. J. Mineralogy of oxisols and oxic materials. In: Theng, B. K. G (ed) Soils with variable charge. New Zealand Soc. Soil. Sci. p. 109-126, 1981.

HOHL, H.; SIGG, L.; STUMM, W. Characterization of surface chemical properties of oxides In: Natural Waters. Adv, Chem. Ser n. 189, p. 131,1980 .

HUGHES, J. C. Mineralogy. In: GREENLAND, D. J (ed) The caracterization in relation to their classification and manegement for crop production: examples from some areas of the humid tropics, p. $30-50,1981$ 
ITAMI, K.; KITAGAWA, Y.; KYUMA, K.; KOSAKI, T. Effect of removal of free oxides on changes in dispersibility and charge characteristics of soils. Soil S cience Plant Nutrition v. 42 n.3 p. 593-602, 1996.

JACKSON, M. L. Soil Chemical Analisys; advanced course. Madison, University of Wisconsin Published by the autor, 1969. 894p.

JACKSON, M. L. Clay transformation in soil genesis during the Quatemary. Soil Science v.99 p.15-22, 1965.

JACKSON, M. L. Chemical composition of soils. In: BEAR, F. E (Ed) Chemistry of the soil. $2^{\text {a }}$ ed. Reinhold Publ. Co., New York, 1964. p. 71 141 .

JAMES, R. O.; PARKS, G. A. Characterization of aqueuos colloids by their electrical double layer and intrinsic surface chemical properties. Surface colloid science.v.12, p.119-216, 1982.

JANOT, C.; GIBERT, H. Étude des substituitions Al-Fe dans des roches latériques. Bol. Soc. Fr. Mineral Cristallography v. 94, p. 13-22, 1966.

JONES, R. C.; UEHARA, A. G. Amorphous coatings on mineral surfaces. Soil Science Society of America. Proceeding. v. 37, p.792-798, 1973.

JUO, A. S. R. Chemical characteristics. In: Greenland, D. J (Ed). The characterization in relation to their classification and management for crop production: examples from some areas of the humid tropics, p. 51-79, 1981. Claredon Press, Oxford.

KÄMPF, N.; AZEVEDO, A. C.; COSTA JR, M. I. Estrutura básica de argilomineral 2:1 com hidróxi-Al entrecamadas em Latossolo Bruno do Rio Grande do Sul. Revista Brasileira de Ciências do Solo, v.19, n. 2 p.185-190, 1995. 
KÄMPF, N; RESENDE, M.; CURI, N. Iron oxides in Brazilian oxisols. In: International Soil Classification Workshop. 8. Brazil, 1986. Proccedinng a Rio de Janeiro: EMBRAPA, 1988, p.71-77.

KÄMPF, N.; SCHWERTMANN, U Quantitative determination of goethite and hematite in kaolinites soils by $x$-rays diffraction. Clay Minerals v.17, p. 359-363, 1982.

KAMPRATH, E. J. Potential detrimental effects from liming highly wathered soils to neutrality. Proceeding of Soil \& Crop. Science Society. FL., v. 31, p.200-203, 1971.

KAVANAGH, B. V.; QUIRK, J. P. The adsorption of polycationic Fe (III) species on Na-illite. Geoderma, v.21, p.225-238, 1978.

KENG, J. C. W ; UEHARA, A, G. Chemistry, mineralogy and Taxonomy of Oxisols and Ultisols. Soil Crop Sci. Soc. Florida Proc. v.33, p.119-126, 1974.

KINNIBURGH, D. G. ; JACKSON, M. L. Cation adsorption by hydrous metal oxides and clay. In: Adsorption of Inorganics at Solid Liquid Interfaces, p.91-160. ANDERSON, M.A. \& RUBIN, A. J. (Ed.) Amn Arbor Science, Ann Arbor, MI. 1981.

KRISHANMURTI, G. R. S.; SARMA, V. A.K; RENGGASAMY, P. Amorphous ferrialuminossilicates in some tropical ferruginous soils. Clay Mineral v.11, p.137-146, 1976.

KRISHANMOORTY, C.; OVERSTREET, R. An experimental evaluation of ionexchange relationship. Soil Science v. 69, p. 41-53, 1949.

KOMARNENI, S. Cesium sorption and desorption behavior of kaolinites. Soil Science Society America Journal v. 42 p, 531-532, 1978. 
LAVERDIÈRE, M. R.;WEAVER, R. M. Charge characteristics of spodic horizons. Soil Science Society of America Journal, v.41, p.505-510, 1977.

LEPSH, I. F.; BUOL, S. W. Investigation in na Oxisol-Ultisol toposequence in S. Paulo State, Brazil. Soil Science Society of America Proceeding, v.38, n.3 p. $491-496,1973$.

LE ROUX. Quantitative clay mineralogical analysis of Natal oxisols. Soil Science v. 115, p. 137-144, 1973.

LEWIS-RUSS, A. Measurement of surface charge of inorganic geological materials: techniques and their consequences. Advance in Agronomy. v.46, p.199-243, 1991.

LIM, C. H.; JACKSON, M. L.; KOONS, R. D.; HEIMKE, P. A. Kaolins: sources of differents cation exchange capacities and cesium retention. Clays Clay Minerals v.28, p. 223-229, 1980.

LOYOLA JR, E.; PAVAN, M. A. Seletividade de troca de cátions em solos ácidos. Revista Brasileira de Ciências do Solo v.13, n.2, p. 131-138, 1989.

MADRID, L.; DIAZ, E.; CABRERA, F. Charge properties of mistures of minerals with variable and constant surface charge. Journal of Soil Science v.35, p.373-380, 1984.

MAGALHÃES, A.F; PAGE, A. L. Características das cargas elétricas da Zona da Mata de Pernambuco. I Determinação das cargas de superfície. Revista Brasileira de Ciências di Solo, Campinas v.8, p. 173-177, 1984.

MAGUIRRE, S. PULFORD, I. D; COOK, G. T; MACKENZIE, A. B. Caesium sorption- desorption in clay-humic acid system. Journal of Soil Science v.43, p.689-696, 1992. 
MAHAN, B. H. Química- um curso universitário $2^{a}$ ed. Editora Edgar Blücher Ltda, 1972. 654p.

MARCANO-MARTINEZ, E. ; McBRIDE, M. B. Comparison of the titration and ion adsorption methods for surface charge measurement in Oxisols. Soil Science Society of America Journal n 53, p. 1040-1045, 1989.

McBRIDE, M. B. Environmental chemistry of soils. Oxford University Press. New York, N. Y. 1994. 406p.

McBRIDE, M. B. Surface chemistry of soil minerals. In: DIXON, J. B \& WEED, S. B. (Eds.) Minerals in Soil Environments. 2nd edition. Soil Science Society of America. Madison, WI. 1989.

MISAK, N. Z.; PETRO, N. S. P.; GNONEIMY, H. F.; SALAMA, H. N. On the effect of the physicochemical properties of ferric oxide gels on their iron exchange behaviour. Reactive Polymers v. 8, p.69-77, 1988.

MISONO, M.; OCHIA, E.; SAITO, Y.; YONEDA, Y. A new dual parameter scale the strengh of Lewis acids and bases with the evaluation of their softness. Journal Inorg. Nuclear Chemistry v.29, p. 2685-2691, 1967.

MITCHELL, J.K. Fundamentals of soil behavior .Berkley, University of California / John Wiley, 1976,. 422p.

MITCHELL, B. D.; MACKENZIE, R. C. Removal of free iron oxide from clays. Soil Science v. 77 p. 173-184, 1954.

MÖLLER, M. R. F.; KLAMT, E. Identificação e gênese de argilominerais em latossolo roxo de Santo Ângelo (RS). Revista Brasileira de Ciências do Solo v. 6, n.3 p.161-166, 1982

MONIZ, A. C.; JACKSON, M. L. Quantitative mineralogical analysis of Brasilian soils derived from basic rocks and slate. University Wisconsin. Madison, Wisconsin Soil Science Report, 212, 1967. 74p. 
MOORE, D. M.; REYNOLDS Jr, R. C. X-ray diffraction and identification and analysis of clay minerals, 1989. Oxford University Press, New York.

MORAIS, F.J.I.; PAGE,A.L.; LUND,L.J. The effect of $\mathrm{pH}$ salt concentration and nature of eletrolytes on the charge characteristics of Brazilian tropical Soils. Soil Science Society of America Journal. Madison, .v.40, p.521-7, 1976.

MOTCHI, E. P. Características e gênese de uma seqüência de oxissolos no Planalto Central Brasileiro. Dissertação (M. S). Univ. Federal do Rio Grande do Sul (UFRGS)- Dep ${ }^{\text {to }}$. de Solos. Porto Alegre, 1977. 107p.

MOTT, C, J. B. Anion and ligand exchange In: GREENLAND, D. J. \& HAYES, M. H.B (Eds) The chemistry of soil process p. 179-219, 1981. Wiley, New York.

MOURA FILHO, W.; BUOL, S. W. Stusies of a Latossol Roxo (Eutrustox) in Brazil. Clay mineralogy experientiae. v.13, p.201-217, 1972.

MUSIC, S.; RISTIC, M. Adsorption of traces elements or radionuclides on hyfdrous iron oxides. Journal Radioanalysis. Nuclear Chemistry Articles v. 120, p. 289-304, 1988.

MURRAY, J. W. The surface chemistry of hydrous manganese dioxide.Journal Colloid and Interface Sci. v.46, p 357-371,1974.

NAIDU, R.; SYERS, J.K.; TILLMAN, R.W.; KIRKMAN, J.H. Effect of liming and added soils phosphate on charge characteristics of acid soils. Journal of Soil Science, Oxford v. 41, n.1, p.157-64, 1990. 
NASCIMENTO, R.A.M.; CUNHA, L. H.; RAMOS, D. P. Comparações entre ponto de carga zero (titulação potenciométrica), mineralogia e diversos outros parâmetro, para quatorze perfis de latossolos. In: REUNIÃO DE CLASSIFICAÇÃO, CORRELAÇÃO DE SOLOS INTERPRETAÇÃO DE APTIDÃo AGRíCOLA, 3, Rio de Janeiro, 1988. Anais. Rio de Janeiro, EMBRAPA-SNLCS/SBCS, 1988. p. 365-390.

NISHITA, H.; TAYLOR, P.; ALEXANDER, G. V.; LARSON, K. H. Influence of stable $\mathrm{Cs}$ and $\mathrm{K}$ on the reactions of $\mathrm{Cs} 137$ and $\mathrm{K} 42$ in soils and clay minerals. Soil Science v. 94, p. 187-197, 1962.

NORRISH, K; TAYLOR, R, M. The isomorphous replacement of iron by aluminium in soil goethites. Journal of Soil Science v.12, p.294-306, 1961 .

OADES, J. M. An introduction to organic matter in mineral soils p. 89. In: DIXON, J B \& WEED, S. B (Es) Minerals in soil environments. SSSA, Madison, WI, 1989.

OADES, J. M. Soil organic matter and structural stability: mechanisms and implications for management. Plant \& Soil v. 76. p.319-337, 1984.

OLIVEIRA, , J.B.; PRADO, H. Levantamento pedológico semi-detalhado do Estado de S. Paulo: quadrícula de Guaíra. Campinas, Instituto Agronômico de Campinas, 1992.

OLIVEIRA, J. B.; RESENDE, M.; CURI, N. Caracterização e classificação de latossolos variação Una e de solos afins da região de Guaíra, SP. Revista Brasileira de Ciências do Solos, Campinas v.15 p. 207-218, 1991. 
OLIVEIRA, J. B.; PRADO, H. Levantamento pedológico semi-detalhado do Estado de S. Paulo: quadrícula de Ribeirão Preto. II. Memorial descritivo Campinas. Instituto Agronômico, 1987. 133p. (IAC. Boletim Científico,n.7).

OLIVEIRA, J. B; MENK, J. L. F. Latossolos roxos do Estado de São Paulo. Campinas, Instituto Agronômico, 1984. 135p. (IAC Boletim Técnico, n.82).

OLIVEIRA, J. B. Latossolos da quadrícula de Campinas, SP. II. Características Físicas e Mineralógicas; Correlação com as classificações americana, francesa e FAO. Revista Brasileira de Ciências do Solo

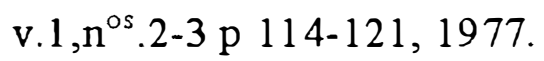

PALMIERI, F. A. Study of a clomossequence of soils derived from volcanic rock parent material in Santa Catarina and Rio Grande do Sul, Brazil. PhD. (Thesis). Perdue University, West Lafayette, IN.1986.

PARFITT, R.L.; GILTRAP, D. J.; WHITTON, J. S. Contribution of organic matter and clay minerals to the cation exchange capacity of soils. Communication in Soil Science Plant Analysis, v.26, n. $9 \& 10$, p. 13431355, 1995.

PARFITT, R. L.; HENG, L. K.; TAYLOR, M. D. Sorption of ions by soil organic matter and clay-organics at low ionic strenght. In: HUANG, P. M; BERTHELIN, J.; BOLlaG, J. M.; McGill, W. B \& PAGE, A. L (Ed). Environmental impacts of soil components interactions. Lewis Publishers, 1994. 
PARFITT, R. L. Chemical properties of variable charge in soils. In: THENG, B. K. G (Ed) Soils with variable charge. New Zealand: New Zealand Soil Sc. Soc. Lower Hutt, 1980. cap. 10, p. 167-194.

PARFITT, R. L.; ATKINSON, R. J; SMART, R. St. C. The mechanisms of phosphate fixation by iron oxides. Soil Science Society of America Journal, v.39, p.837-841,1975.

PARKER, J.C., ZELAZNY, L.W; SAMPATH, S; HARRIS, W. G. A critical evaluation of the extension of zero point of charge (ZPC) theory to soil systems. Soil Science Society of American Journal., 43: 668-674, 1979.

PARKS, G. A. Surface chemistry of oxides in aqueous systems. In: STUMM W.(Ed.) Equilibrium Concepts in Aqueous Systems, pp. 121-160. Adv. Chem. Ser. n.67, Am. Chem. Soc., Washington, D.C. 1967a.

PARKS, G .A. Aqueous surface chemistry of oxides and complex oxide minerals: isoelectric point and zero point of charge. In: STUMM W (Ed.) Equilibrium Concepts in Natural Water Systems. Advances in Chemistry Series, n. 67. Amer. Chem. Soc. Washington, D.C.1967b.

PARKS, G. A. The isoeletric points of solid oxides, solid hydroxides, and aqueous hidroxo complex systems. Chemistry Rev., v.65, p.177-198, 1965.

PARKS, G. A; BREUYN, P.L de. The zero point of charge of oxides. Journal Physics. Chemistry v.66, p. 967-73, 1962.

PEARSON, R. G. Hard and soft acids and bases. Journal American Chemistry Society v. 33, p. 3533-3 539, 1963. 
PEIXOTO, R. T. G Matéria orgânica e a geração de cargas elétricas em solos do Paraná. In: Encontro Brasileiro sobre Substâncias Húmicas 2, São Carlos, 1997; Anais. São Carlos: EMBRAPA, CNPDIA, 1997. p186.

PEIXOTO, R. T. G. Surface chemical properties of oxisols derived from Paraná basalt (Brazil). Ohio, 1995, 188p. Dissertation (Doctor)- School of the Ohio State University.

PEIXOTO, R. T. G; TRAINA, S. J.; BIGHAM; J. M. Aplicabilidade do método de adsorção de Cs na determinação de carga elétrica permanente em Latossolos derivados de basalto no Paraná. In: XXV Congresso Brasileiro de Ciência do Solo. Viçosa-MG. Vol. I:295-297, 1995a.

PEIXOTO, R.T.G; TRAINA, S. J.; BIGHAM; J. M. Propriedades químicas de superficie em função da composição mineral e matéria orgânica em Latossolos derivados de basalto no Paraná. In: XXV Congresso Brasileiro de Ciência do Solo. Viçosa -MG. Vol. I:298-300, 1995 b.

PÉREZ, D. V.; RAMOS, D. P.; NASCIMENTO, R. A. M.; BARRETO, W. O. Propriedades eletroquímicas de horizontes $B$ texturais. Revista Brasileira de Ciências do Solo v. 17, n.2 p.157-164, 1993.

PERROTT, K. W. The influence of organic matter extracted from humified clover on the properties of amorphous aluminosilicates. I. Surface charge. Australian Journal Soil Reshearch., v. 16, p 327-329, 1978.

PERROTT, K. W. Surface charge characteristics of amorphous aluminosilicates. Clays Clay Miner. v.25, p. 417-421, 1977. 
POLUBESOVA, T. A. CHOROVER, J.; SPOSITO, G. Surface charge characteristics of podzolized soil. Soil Sccience Society of America Journal v. 59, p. 772-777, 1995.

RAIJ, B. van. Propriedades eletroquímicas de solos. In: DECHEN, R. A \& CARmello, Q. A. C.(coord.) Anais do Simpósio Avançado de Química e Fertilidade do Solo. 1. Piracicaba, , 1986. p. 9- 41.

RAIJ, B. van. Determinação de carga elétrica em solos. Bragantia, Campinas, v.32, n. 7, p.171-183, 1973a.

RAIJ, B. van. Determinação do ponto de carga zero em solos. Bragantia, Campinas, v.32, n.18, p.337-347, 1973 b.

RAIJ, B van; PEECH, M. Electrochemical properties of some oxisols and alfisols of the tropics. Soil Science Society of America Proceeding, v.36, p.587-93, 1972.

RAIJ, B. van. A capacidade de troca de cátion das frações orgânicas e mineral em solos. Bragantia v. 28, n.8 p.85-1121969.

RAZAQ, J. B.; TABATAI, M.A. Determination of surface charge density of soils. Communication. in Soil Science and Plant Analysis v.21, p. 125, 1990.

RENGASAMY, P.; OADES, J. M. Interaction of monomeric and polimeric species of metal ions with clay surfaces.IV. Mixed system of aluminium (III) and iron (III). Australian Journal of Soil Research v.17, p. 141-154, 1979.

RENGASAMY, P.; OADES, J. M. Interaction of monomeric and polimeric species of metal ions with clay surfaces. III. Aluminium (III) and chromium (III). Australian Journal of Soil Research v.16, p. 53-66,1978. 
RENGASAMY, P.; OADES, J. M. Interaction of monomeric and polimeric species of metal ions with clay surfaces. I. Adsorption of iron (III) species. Australian Journal Soil Research v. 15, p.221-233, 1977 a.

RENGASAMY, P.; OADES, J. M. Interaction of monomeric and polimeric species of metal ions with clay surfaces. II. Changes in surfaces properties of clays after addition of iron (III). Australian Journal of Soil Research v. 15, p. 235-242, $1977 \mathrm{~b}$.

RESENDE, M. Mineralogy, chemistry, morphology and geomorphology of some soils of the Central Plateau of Brazil, Ph.D (Thesis). Purdue. University, West Lafayette, In. 237p.

RICH, C. I; BLACK, W.R. Potassium exchange as affectedby cation size, $\mathrm{pH}$ and mineral structure. Soil Science v.97, p.384-390, 1964.

RICH, C. I. Removal of excess salts in cation exchange capacity determination. Soil Science v.93, p.87-92, 1962.

ROTH, C. B.; JACKSON, M. L.; SYERS, J. K. Deferrefication effect on strutural ferrous-ferric iron cation and cec of vermiculites and soils. Clays Clay Min. v. 17 p.253-264, 1969.

RODRIGUES, T. E.; KLAMT, E. Mineralogia e gênese de uma seqüência de solos do Distrito Federal. Revista Brasileira de Ciências do Solo v. 2. n.2 p. 132-139, 1978.

RUSSEL, J.D., R.L. PARFITT, A.R. FRASER; V.C. FARMER. Surface structures of gibbsite, goethite and phosphated goethite. Nature, v. 248 p. $220-221,1974$. 
SAKURAI, K.; NAKAMURA, Y.; KYUMA, K. Changes in zero point of charge (ZPC), phosphate retention and specific surface area of some variable charge soil after several chemical treatments. Soil Science and Plant Nutrition., Tokyo. v.37, n.3, p.435-444, 1991.

SAKURAI, K.; TESHIMA, A.; KYUMA, K. Changes in zero point of charge (ZPC), specific surface area (SSA), and cation exchange capacity (CEC) of kaolinite and montmorillonite, and strongly weathered soils caused by $\mathrm{Fe}$, and Al coatings. Soil Science and Plant Nutrition, Tokyo, v.36, n.1, p.73-81,1990.

SAKURAI, K.; OHDATE, Y.; KYUMA, K. Factors affecting zero point of charge ( ZPC) of variable charge soils. Soil Science and Plant Nutrition., Tokyo. v.35, n.1, p.21-31, 1989.

SANTANA, D. P. Soil formation in a topossequence of oxisols from Patos de Minas Region, Minas Gerais State. Brazil.Thesis(Ph.D). Perdue Univ., Lafayette, Ind $129 \mathrm{p}$.

SAWHNEY, B. L. Selective sorption and fixation of cations by clay minerals: a review. Clays Clay Miner. v.20, p.93-100, 1972.

SAWHNEY, B. L. Potassium and cesium ion selectivity in relation to clay mineral structure. Clays Clay Miner. v. 18 p.47-52, 1970.

SAWHNEY, B. L. Kinetics of cesium sorption by clay minerals. Soil Science Society American Proceedings. v. 30, p.565-569, 1966.

SCHOFIELD, R. K.; SAMSON, H. R. Deflocculation of kaolinite suspensions and the accompanying charge over from positive to negative adsorption. Clay Mineral Bull v.2, p.45-50, 1953.

SCHOFIELD, R. K. Effect of $\mathrm{pH}$ on electric charges carried by clay particles. Journal of Soil Science v. 1, p. 1-8, 1949. 
SCHULTHESS, C. P.; SPARKS, D. L. Equilibrium based modeling of chemical sorption on soils and soil constituents. Advance in Soil Science v. 16, p. 121,1991 .

SCHULZ, R. K.; OVERSTREET, R; BARSHAD, I. On the soil chemistry of cesium 137. Soil Science, v.89, p.16-27, 1960.

SCHWERTMANN, U.; LATHAM, M. Properies of iron oxides in some New Caledonian soils. Geoderma, v. 39 p. 105-123, 1986.

SCHWERTMANN, U. The effect of pedogenic environments on iron oxide minerals. Adv. Soil Sci. v.1 p.171-2001985

SCHWERTMANN, U.; CARLSON, L.; FECHTER. H. Ironn oxide formation in artificial ground waters. Schwiz. Z. Hydrol. V. 46 p. $185-191,1984$.

SCHWERTMANN, U; KODAMA, H; FISHER, W. R. Mutual interactions between organics and iron oxides.p. 223-250. In: HUANG, P. M \& SCHNITZERI (eds). Interactions soil minerals with natural organics and microbes. Spec. Pub.17. 1968. SSSA, Madison, W.I

SHUMAN, L. M. Zinc adsorption isotherms for soil and clays with and without iron oxides removed. Soil Science S ociety American Proceeding. v. 40 p. $349-355,1976$.

SiQUEIRA, C.; LEAL, J. R.; VElloso, A. C. X.; SANTOS, G. A. Eletroquímica de solos tropicais de carga variável. I. Influência da matéria orgânica no tempo de equilíbrio para determinação das curvas de titulação potenciométrica. Revista Brasileira de Ciências do Solo v.14 n. 1 p.7-11, 1990a.

SIQUEIRA, C.; LEAL, J. R.; VElloso, A. C. X; SANTOS, G. A. Eletroquímica de solos tropicais de carga variável. II. Quantificação do 
efeito da matéria orgânica sobre o ponto de carga zero. Revista Brasileira de Ciêrncias do Solo v.1 4 n. 1 p.13-17, 1990 b.

SIQUEIRA, C.; LEAL, J. R.; VElloso, A. C. X.; SANTOS, G. A. Eletroquímica de solos tropicais de carga variável: III. Erros na avaliação das cargas. Revista Brasileira de Ciências do Solo v.14 n. 1 p.19-24, $1990 \mathrm{c}$.

SIQUEIRA, C. Eletroquímica de solos tropicais de carga variável: efeitos da matéria orgânica, Itaguaí, 1985. 133p. (Doutorado- Universidade Federal Rural do Rio de Janeiro).

SPOSITO, G. The characterization of particles charge. In: Environmental Particles. BUFFEL, J. \& van LEEUVEN (eds.). IUPAC Publications in Environmental and Analytical Chemistry, Vol. 1. 1992.

SPOSITO, G. The Chemistry of Soils New York, Oxford, Claredon Press, 1989. 262p.

SPOSITO, G. The Surface Chemistry of Soils. Oxford University Press, Oxford. UK. 1984.

SPOSITO, G. On the measurements of permanent charge in Oxisols. Soil Science Society of America Journal v. 47 p. 1058-1059, 1983.

SPOSITO, G. The Thermodinamics of soil solutions. Oxford, Clarendon Press, 1981.262p.

STEVENSON, F. J. Humus chemistry: genesis, composition, reactions. New York, Wiley \& Sons, 1994. 496p. 
STOOP, W. Ion adsorption mechanisms In oxidic soils; implications for point of zero charge determinations. Geoderma, Amsterdan, v.23, p.30314,1980 .

STUMM, W. Chemistry of the Solid-Water Interface. John Wiley and Sons, New York, 1992. 428p.

STUMM, W.; MORGan, J. J. Aquatic Chemistry. Wiley-Interscience. New York. 1981.780p.

SULLIVAN, P.J. The principle of hard and soft acids and bases as applied to exchangeable cation selectivity in soils. Soil Sci., v.124 p.117-121, 1977.

SUMNER, M. E. The electrical double layer and clay dispersion. In: Soil crusting chemical and physical process. New York, Lewis. v.1. 1992.

SUMNER, M. E. Effect of iron oxides on positive and negative charges in clays and soils. Clay Mineral Bull v.5 p. 218-226, 1963.

SUMNER, M. E. The effect of sodium ditionite on the surface properties of clays. Agrochimica, v. 6 p. 183-89, 1962.

SVERJENSKY, D. A. Zero point of charge prediction from crystal chemistry and solvation theory. Geochemica et Cosmochimica Acta v.58 p.3123, 1994.

TAMURA, T. Reactions of cesium-137 and strontium-90 with soil minerals and sesquioxides. In: International Congress Soil Science, $8^{\text {th }}$, Bucarest, Romania, 1964. p.465-478.

TESSENS, E; ZAUYAH, S. Positive permanent charge in Oxisols. Soil Science Society American Journal., v.46 p.1103-1106, 1982. 
TIEN, H. T. Polifunctionality and equilibrium coefficient of ion-exchange systems. Reaction of alkali metal cation with phosphoric and resins. Journal Physics Chemistry v.68, p.1021-1025, 1964.

TSCHAPEK, M.; TCHEICHVILLI, M.; WASOWSKY, C. The point of zero charge (ZPC) of kaolinite and $\mathrm{SiO}_{2}+\mathrm{Al}_{2} \mathrm{O}_{3}$ mixtures. Clay Min. v. 10, p.219-229, 1974.

TWENOBOAH, C. K.; GREENLAND, D. J.; OADES, J. M. Changes in charge characeristics of soil after treatment with $0,5 \mathrm{M}$ calcium chloride at pH 1,5. Australian Journal Soil Research v. 5, p. 247-261, 1967.

UEHARA, G.; GILLMAN , G. The mineralogy, chemistry and physics of tropical soils with variable charge clays. Boulder, Wetview Press, 1981. 170p.

UEHARA, G.; GILLMAN, G. Charge characteristics of soils with variable and permanent charge minerals: I. Theory. Soil Science Society of America Journal. v.44, p.250-252, 1980.

UEHARA, G. Mineral-chemical properties of Oxisols In : PROCEEDINGS OF SECOND INTERNATIONAL SOIL CLASSIFICATION WORKSHOP. Malásia, 1978. Part. I Bangkok, Thailand: Soil Survey Division, Land Development Department, 1979., p. 45-60.

UEHARA, G. Acric properties and their significance to soil classification. In: INTERNATIONAL SOIL CLASSIFICATION WORKSHOP, 8, Rio de Janeiro, 1986. Proceedings. Rio de Janeiro. EMBRAPA/ SNLCS, 1988., p. 19-22. 
VANSELOW, A. P. Equilibria of the base-exchange reaction of bentonites, permutites, soil colloids and zeolites. Soil Science, Baltomore, v.33 p.95-113, 1932.

VETtORI, L. Métodos de Análises de Solos. Ministério de Agricultura. Equipe dePedologia e Fertilidade do Solo. Boletim Técnico, n. 07. Rio de Janeiro, 1969. 24p.

WADA,S.J.; WADA, K. Change characteristics and exchangeable cation status of Korean Ultisols and Alfisols and Thai Ultisols and Oxisols. Journal of Soil Science, London, v. 36, p. 21-9,1985.

WADA, K. Mineralogical characteristics of andosols. In: THENG, B. K. G (Ed) Soils with variable charge. New Zealand Society of Soil Science, 1980. $87 \mathrm{p}$.

WADA, K.; GREENLAND, D. J. Selective dissolution and differential infrared spectroscopy for characterization of "amorphous" constituents in soil clays. Clay Minerals v.8, p.248-254, 1970.

WANN, S. S.; UEHARA, G. Surface charge manipulation of constant surface potential soil colloids: I. Relation to sorbed phosphorus. Soil Science Society of America Journal, Madison, v.42, p. 565-9 0. 1978.

WEAVER, C. C.; POLLARD, L. D. The chemistry of clay minerals. Elsevier Sci., New York, 1975.

WEED, S. B; NELSON, L. A. Occurrence of chlorite-like intergrade clay minerals, in Coatal Plain, Piedmont and Mountain soils of North Caroline. Soil Science Society of America Proceeding v. 26 p. 393- 398, 1962. 
WEISS, C. A. Jr.; ALTNER, S. P. The structural environmental of cations adsorbed onto clays ${ }^{133} \mathrm{Cs}$ variable-temperature MAS-NMR spectronic study of hectorite. Geochemistry et Cosmochemica Acta v.54, p.1655$1669,1990$.

WHITE, G. N.; ZELAZNY, L. W. Charge properties of soil colloids. In: SPARKS, D. L (Ed) Soil Physical Chemistry p. 38-81. CRC Press, Boca Raton, FL. 1986.

WIKLANDER, L.; Cation and anion exchange phenomena In: BEAR, F. E. (Ed) Chemistry of the soil, 2 nd ed., Reinhold, New York. 1964.

$\mathrm{XU}, \mathrm{S}$. ; HARSH, J. Alkali cation selectivity and surface charge of 2:1 clay minerals. Clays Clay Miner., v.40 p.567-574, 1992.

XU, S.; J. HARSH, J. Monovalent cation selectivity quantitatively modeled according to hard/soft acid/base theory. Soil Science Society of America Journal, v.54 p.357-363, 1990 a.

XU, S.; HARSH, J. Hard and soft acid-base model verified for monovalent cation selectivity. Soil Science Society of America Journal, v.54, p.1596-1601, 1990 b.

YU, T. R. Chemistry of variable charge soils. New York, Oxford University Press, 1997.

ZHANG, X. N.; JIANG, N. H. Studies on eletrochemical properties of soils. III. Charge characteristics of the clay fraction of red soils. Acta Pedologica Sinica v. 12, p. 120-131, 1964. (in Chinese). 


\section{APÊNDICES}


APÊNDICE 1. Coeficientes de seletividade condicionais ( ${ }^{C} \mathrm{Kex}$ ) para troca de $\mathrm{Li}^{+} \rightarrow \mathrm{Cs}^{+}$e frações molares $(x \mathrm{Cs})$ de $\mathrm{Cs}^{+}$em uma Terra Roxa Estruturada e em solos ácricos originais.

\begin{tabular}{|c|c|c|c|c|c|c|}
\hline Solo & Prof $(\mathrm{cm})$ & ${ }^{\mathrm{C}} \mathrm{Kex}$ & $x \mathrm{Cs}$ & $x \mathrm{Li}$ & $\mathrm{kCs}$ & $\mathrm{kLi}$ \\
\hline & & & & & $\ldots-m_{m}$ & $5^{-1}$ solo---- \\
\hline \multirow[t]{3}{*}{$\mathrm{TE}$} & $0-20$ & $10,6\left(0,3^{1}\right)$ & $0,45(0,00)$ & $0,54(0,00)$ & $0,72(0,00)$ & $9,27(0,00)$ \\
\hline & $75-95$ & $26,4(0,9)$ & $0,53(0,00)$ & $0,46(0,00)$ & $0,42(0,00)$ & $9,58(0,00)$ \\
\hline & média & $18,5(11,1)$ & $0,49(0,05)$ & $0,90(0,50)$ & $0,57(0,20)$ & $9,43(0,22)$ \\
\hline \multirow[t]{3}{*}{ LRác-Rib } & $0-20$ & $12,0(0,9)$ & $0,29(0,01)$ & $0,79(0,01)$ & $0,33(0,01)$ & $9,67(0,01)$ \\
\hline & $100-140$ & $23,9(2,5)$ & $0,33(0,01)$ & $0,66(0,01)$ & $0,21(0,00)$ & $9,79(0,01)$ \\
\hline & média & $18,0(8,4)$ & $0,31(0,03)$ & $0,68(0,03)$ & $0,27(0,09)$ & $9,72(0,09)$ \\
\hline \multirow[t]{3}{*}{ LRácGuaí } & $0-20$ & $8,3(0,4)$ & $0,24(0,00)$ & $0,75(0,00)$ & $0,38(0,00)$ & $9,62(0, \infty 0)$ \\
\hline & $100-150$ & $19,7(0,2)$ & $0,27(0,00)$ & $0,73(0,00)$ & $0,18(0,00)$ & $9,81(0, \infty)$ \\
\hline & média & $14,0(8,1)$ & $0,26(0,02)$ & $0,74(0,02)$ & $0,28(0,13)$ & $9,72(0,13)$ \\
\hline \multirow{3}{*}{$\begin{array}{l}\text { LUna } \\
\text { ác-argare }\end{array}$} & $0-20$ & $24,5(1.9)$ & $0,29(0,01)$ & $0,70(0,01)$ & $0,16(0,00)$ & $9,83(0,00)$ \\
\hline & $30-70$ & $30,8(1.7)$ & $0,26(0,00)$ & $0,73(0,00)$ & $0,12(0,00)$ & $9,88(0,01)$ \\
\hline & média & $27,6(4.5)$ & $0,28(0,02)$ & $0,72(0,01)$ & $0,14(0,03)$ & $9,86(0,03)$ \\
\hline \multirow{3}{*}{$\begin{array}{l}\text { LUna } \\
\text { ác- mtarg }\end{array}$} & $0-20$ & $7,6(0,3)$ & $0,24(0,00)$ & $0,76(0,00)$ & $0,39(0,00)$ & $9,60(0,00)$ \\
\hline & $60-90$ & $20,4(0,8)$ & $0,31(0, \infty)$ & $0,69(0,00)$ & $0,21(0,00)$ & $9,78(0,00)$ \\
\hline & média & $14,0(9,1)$ & $0.27(0,05)$ & $0,72(0,05)$ & $0,31(0,13)$ & $9,69(0,13)$ \\
\hline
\end{tabular}


APÊNDICE 2 Coeficientes de seletividade condicionais ( ${ }^{\mathrm{C}} \mathrm{Kex}$ ) para troca de $\mathrm{Li}^{+} \rightarrow \mathrm{Cs}^{+}$e frações molares ( $x \mathrm{Cs}$ ) de $\mathrm{Cs}^{+}$em uma Terra Roxa Estruturada e em solos ácricos com matéria orgânica removida.

\begin{tabular}{|c|c|c|c|c|c|c|}
\hline \multirow[t]{2}{*}{ Solo } & \multirow[t]{2}{*}{ Prof $(\mathrm{cm})$} & \multirow[t]{2}{*}{${ }^{\mathrm{C}} \mathrm{Kex}$} & \multirow[t]{2}{*}{$x \mathrm{Cs}$} & \multirow[t]{2}{*}{$x_{L i}$} & \multirow{2}{*}{\multicolumn{2}{|c|}{$\begin{array}{c}\mathrm{K}_{\mathrm{Cs}} \\
\mathrm{K}_{\mathrm{Li}} \\
\cdots \mathrm{mmol}_{\mathrm{C}} \mathrm{kg}^{-1} \cdots\end{array}$}} \\
\hline & & & & & & \\
\hline \multirow[t]{3}{*}{$\overline{T E}$} & $0-20$ & $32,3(0,6)$ & $0,50(0,00)$ & $0,50(0,00)$ & $0,30(0,00)$ & $9,70(0,00)$ \\
\hline & $75-95$ & $38,6(8,1)$ & $0,50(0,00)$ & $0,50(0,00)$ & $0,25(0,03)$ & $9,74(0,03)$ \\
\hline & média & $35,4(4,4)$ & $0,50(0,00)$ & $0,50(0,00)$ & $0,28(0,03)$ & $9,72(0,03)$ \\
\hline \multirow[t]{3}{*}{ LRác-Rib } & $0-20$ & $10,0(0,4)$ & $0,37(0,01)$ & $0,62(0,01)$ & $0,57(0,00)$ & $9,42(0,00)$ \\
\hline & $100-140$ & $7,3(0,8)$ & $0,31(0,02)$ & $0,68(0,00)$ & $0,59(0,00)$ & $9,40(0,00)$ \\
\hline & média & $8,6(1,9)$ & $0,34(0,04)$ & $0,65(0,04)$ & $0,58(0,01$ & $9,41(0,01)$ \\
\hline \multirow[t]{3}{*}{ LRác-Gua } & $0-20$ & $13,1(0,4)$ & $0,32(0,00)$ & $0,68(0,00)$ & $0,34(0,00)$ & $9,65(0,00)$ \\
\hline & $100-150$ & $17,4(0,3)$ & $0,32(0,00)$ & $0,68(0,00)$ & $0,26(0,00)$ & $9,73(0,00)$ \\
\hline & média & $15,2(3,0)$ & $0,32(0,00)$ & $0,68(0,00)$ & $0,30(0,06)$ & $9,69(0,06)$ \\
\hline \multirow{3}{*}{$\begin{array}{l}\text { LUna } \\
\text { ácargare }\end{array}$} & $0-20$ & $21,4(2,5)$ & $0,26(0,02)$ & $0,73(0,02)$ & $0,16(0,00)$ & $9,83(0,00)$ \\
\hline & $30-70$ & $25,2(2,4)$ & $0,30(0,01)$ & $0,70(0,00)$ & $0,17(0,02)$ & $9,83(0,02)$ \\
\hline & média & $23,3(2,7)$ & $0,28(0,02)$ & $0,72(0,02)$ & $0,17(0,00)$ & $9,83(0,00)$ \\
\hline \multirow{3}{*}{$\begin{array}{l}\text { LUna ác- } \\
\text { mtarg }\end{array}$} & $0-20$ & $19,1(2,3)$ & $0,38(0,02)$ & $0,62(0,02)$ & $0,31(0,00)$ & $9,69(0,00)$ \\
\hline & $60-90$ & $20,9(0,3)$ & $0,37(0,00)$ & $0,62(0,00)$ & $0,28(0,00)$ & $9,72(0,00)$ \\
\hline & média & $20,0(1,2)$ & $0,38(0,00)$ & $0,62(0,00)$ & $0,29(0,02)$ & $9,70(0,02)$ \\
\hline
\end{tabular}


APÊNDICE 3. Coeficientes de seletividade condicionais ( $\left.{ }^{C} \mathrm{Kex}\right)$ para roca de $\mathrm{Li}^{+} \rightarrow \mathrm{Cs}^{+}$e frações molares ( $x \mathrm{Cs}$ ) de $\mathrm{Cs}^{+}$em uma Terra Roxa Estruturada e em solos com óxido de ferro amorfo removido.

\begin{tabular}{|c|c|c|c|c|c|c|}
\hline \multirow{2}{*}{$\begin{array}{c}\text { Solo } \\
\text { TE }\end{array}$} & \multirow{2}{*}{$\begin{array}{l}\operatorname{Prof}(\mathrm{cm}) \\
0-20\end{array}$} & \multirow{2}{*}{$\frac{{ }_{\mathrm{Kex}}}{8,63(0,4)}$} & \multirow{2}{*}{$\begin{array}{c}x \mathrm{Cs} \\
0,46(0,01)\end{array}$} & \multirow{2}{*}{$\begin{array}{c}x \mathrm{Li} \\
0,54(0,01)\end{array}$} & \multicolumn{2}{|c|}{$\mathrm{K}_{\mathrm{Cs}} \mathrm{mol}_{\mathrm{C}} \mathrm{kg}^{-1} \mathrm{~K}_{\mathrm{Li}}$} \\
\hline & & & & & $0,91(0,00)$ & $9,09(0,00)$ \\
\hline & $75-95$ & $12,35(0,5)$ & $0,48(0,00)$ & $0,52(0,00)$ & $0,70(0,01)$ & $9,30(0,01)$ \\
\hline & média & $10,49(2,6)$ & $0,47(0,01)$ & $0,53(0,01)$ & $0,80(0,15)$ & $9,20(0,15)$ \\
\hline \multirow[t]{3}{*}{ LRác-Rib } & $0-20$ & $7,47(1,7)$ & $0,29(0,04)$ & $0,71(0,04)$ & $0,55(0,01)$ & $9,45(0,01)$ \\
\hline & $100-140$ & $11,23(0,5)$ & $0,32(0,01)$ & $0,68(0,00)$ & $0,41(0,00)$ & $9,59(0,00)$ \\
\hline & média & $9,35(2,6)$ & $0,31(0,02)$ & $0,69(0,02$ & $0,48(0,10)$ & $9,52(0,10)$ \\
\hline \multirow[t]{3}{*}{ LRác-Guaí } & $0-20$ & $20,40(2,8)$ & $0,52(0,04)$ & $0,48(0,03)$ & $0,51(0,00)$ & $9,49(0,00)$ \\
\hline & $100-150$ & $26,90(2,1)$ & $0,53(0,02)$ & $0,47(0,02)$ & $0,41(0,00)$ & $9,59(0,00)$ \\
\hline & média & $23,70(4,6)$ & $0,52(0,01)$ & $0,48(0,00)$ & $0,46(0,07)$ & $9,54(0,07$ \\
\hline \multirow{3}{*}{$\begin{array}{l}\text { LUna- } \\
\text { ác(argare) }\end{array}$} & $0-20$ & $5,93(0,4)$ & $0,10(0,01)$ & $0,90(0,00)$ & $0,20(0,02)$ & $9,80(0,02)$ \\
\hline & $30-70$ & $11,66(0,4)$ & $0,14(0,02)$ & $0,86(0,01)$ & $0,14(0,00)$ & $9,86(0,01)$ \\
\hline & média & $8,80(4,0)$ & $0,12(0,02)$ & $0,88(0,02)$ & $0,17(0,04)$ & $9,83(0,04)$ \\
\hline \multirow{3}{*}{$\begin{array}{l}\text { LUna- } \\
\text { ác(mtarg) }\end{array}$} & $0-20$ & $55,05(2,3)$ & $0,33 .(0,01)$ & $0,67(0,00)$ & $0,09(0,00)$ & $9,91(0,00)$ \\
\hline & $60-90$ & $92,24(4,4)$ & $0,34(0,00)$ & $0,66(0,00)$ & $0,06(0,00)$ & $9,94(0,00)$ \\
\hline & média & $73,65(26,2)$ & $0,34(0,01)$ & $0,66(0,00)$ & $0,08(0,02)$ & $9,92(0,02)$ \\
\hline
\end{tabular}


APÊNDICE 4 Coeficientes de seletividade condicionais ( ${ }^{\mathrm{C}} \mathrm{Kex}$ ) para troca de $\mathrm{Li}^{+} \rightarrow \mathrm{Cs}^{+}$e frações molares $(x \mathrm{Cs})$ de $\mathrm{Cs}^{+}$em uma Terra Roxa Estruturada e em solos ácricos com matéria orgânica e óxidos de ferro livres removidos.

\begin{tabular}{|c|c|c|c|c|c|c|}
\hline \multirow[t]{2}{*}{ Solo } & \multirow[t]{2}{*}{ Prof $(\mathrm{cm})$} & \multirow[t]{2}{*}{${ }^{\mathrm{C}} \mathrm{Kex}$} & \multirow[t]{2}{*}{$x \mathrm{Cs}$} & \multirow[t]{2}{*}{$x \mathrm{Li}$} & $K_{C s}$ & $K_{\mathrm{Li}}$ \\
\hline & & & & & \multicolumn{2}{|c|}{ - mmol $\mathrm{kg}^{-1} \ldots$} \\
\hline \multirow[t]{3}{*}{$\mathrm{TE}$} & $0-20$ & $8,79(0,01)$ & $0,55(0,00)$ & $0,45(0,00)$ & $1,22(0.00)$ & $8,78(0,00)$ \\
\hline & $75-95$ & $7,47(0,04)$ & $0,49(0,01)$ & $0,51(0,00)$ & $1,15(0.00)$ & $8,85(0,00)$ \\
\hline & média & $8,13(0,93)$ & $0,52(0,04)$ & $0,48(0,04)$ & $1,18(0.05)$ & $8,82(0,05)$ \\
\hline \multirow[t]{3}{*}{ LRác-Rib } & $0-20$ & $6,06(0,03)$ & $0,40(0,00)$ & $0,60(0,00)$ & $0,99(0.00)$ & $9,01(0,00)$ \\
\hline & $100-140$ & $8,63(0,20)$ & $0,39(0,00)$ & $0,61(0,01)$ & $0,69(0.00)$ & $9,31(0,00)$ \\
\hline & média & $7,34(1,81)$ & $0,39(0,00)$ & $0,61(0,01)$ & $0,84(0.21)$ & $9,16(0,02)$ \\
\hline \multirow[t]{3}{*}{ LRác-Guaí } & $0-20$ & $27,33(0,01)$ & $0,57(0,00)$ & $0,43(0,00)$ & $0,45(0.00)$ & $9,55(0,00)$ \\
\hline & $100-150$ & $7,69(0,01)$ & $0,27(0,00)$ & $0,73(0,00)$ & $0,45(0.00)$ & $9,55(0,00)$ \\
\hline & média & $17,51(13,9)$ & $0,41(0,21)$ & $0,58(0,02)$ & $0,45(0.00)$ & $9,55(0,00)$ \\
\hline \multirow{3}{*}{$\begin{array}{c}\text { LUna } \\
\text { ác-argare }\end{array}$} & $0-20$ & $7,52(0,02)$ & $0,24(0,00)$ & $0,76(0,00)$ & $0,41(0.00)$ & $9,59(0,00)$ \\
\hline & $30-70$ & $10,99(0,01)$ & $0,30(0,00)$ & $0,70(0,00)$ & $0,38(0.00)$ & $9,62(0,00)$ \\
\hline & média & $9,25(2,46)$ & $0,27(0,04)$ & $0,72(0,04)$ & $0,40(0.02)$ & $9,60(0,00)$ \\
\hline \multirow{3}{*}{$\begin{array}{c}\text { LUna } \\
\text { ác-mtarg }\end{array}$} & $0-20$ & $9,34(0,22)$ & $0,45(0,01)$ & $0,55(0,00)$ & $0,79(0.00)$ & $9,21(0,00)$ \\
\hline & $60-90$ & $11,16(0,04)$ & $0,40(0,00)$ & $0,60(0,00)$ & $0,57(0.00)$ & $9,43(0,00)$ \\
\hline & média & $10,25(1,30)$ & $0,42(0,03)$ & $0,58(0,03)$ & $0,68(0.02)$ & $9,32(0,00)$ \\
\hline
\end{tabular}

'números entre parênteses representam desvio padrão 